\title{
A Critical Analysis of Commercial Speech
}

\author{
David F. McGowan $\dagger$
}

This Comment examines the evolution and analytical structure of the Supreme Court's commercial speech doctrine. The Comment first argues that the Court has failed to articulate a principled definition of commercial speech. The Court has failed in its efforts to define commercial speech because, unlike any other category of speech the Court has created thus far, the Court's definitional efforts focus upon the speaker's motive rather than upon the content of the speech. Notwithstanding the Court's frequent protestations to the contrary, speech becomes commercial speech only when it is motivated by profit. The unacknowledged use of motive to define a purportedly textual category of speech yields a definitional incoherence that results in the unpredictable application of the doctrine. The Comment contends that, at a minimum, the definition of commercial speech should be redrawn in explicitly content-based terms. The Comment next argues that the Court's justifications for giving commercial speech less first amendment protection than other forms of speech are invalid. Those justifications ignore the very value structure of the first amendment that the Court says it applies to commercial speech cases. The true justification for the lesser protection afforded commercial speech lies in the Court's unarticulated suspicion of profit-motivated speech and attendant willingness to allow greater latitude to regulations of such speech. The Comment argues that this justification should be acknowledged and discarded in favor of an explicitly value-based analysis.

I read "no law . . . abridging" to mean no law abridging."

Of course I believe that the present ordinance could constitutionally be apphed to a "merchant" who goes from door to door "selling pots." 2

- Justice Hugo Black

$\dagger$ B.A. 1986, University of California, Los Angeles; J.D. candidate 1990, Boalt Hall School of Law, University of California, Berkeley. Thanks to Professor Robert C. Post, who suggested this topic and tried to teach nee about the first amendment, Professor Daniel B. Rodriguez, who provided many helpful suggestions, and the staff of the California Law Review. Special thanks to Lori, who never fully understood how I could spend weekends in front of a computer terminal with a perfectly good beach less than an hour away.

1. Smith v. California, 361 U.S. 147, 157 (1959) (Black, J., concurring) (enuphasis in original).

2. Breard v. Alexandria, 341 U.S. 622, 650 (1950) (Black, J., dissenting). 


\section{INTRODUCTION}

In recent years the Supreme Court has confronted some very difficult issues regarding the scope of the first amendment's protection of the freedom of speech. ${ }^{3}$ The first amendment's application to commercial speech poses one of the most perplexing of these issues. ${ }^{4}$

Since it gave first amendment protection to commercial speech in 1976, the Court has dealt inconsistently with several important aspects of what has become a separate doctrine within the first amendment. ${ }^{5}$ The Court has neither articulated a coherent theory cxplaining why commercial speech should or should not be protected, ${ }^{6}$ nor defined coinmercial speech in a way that predictably classifies different types of speech. ${ }^{7}$ The Court has established and partially abandoned a test for determining when cominercial speech should receive first amendment protection that suffers from these doctrinal deficiencies and leads to irreconcilable results. ${ }^{8}$ Finally, protection for coinmercial speech has regressed to the point where commercial speech is little better off than it was at the begin-

3. Brennan, The Supreme Court and the Meiklejohn Interpretation of the First Amendment, 79 HARV. L. REv. 1, 1 (1965) ("[t]he Supreme Court's concern with the true significance of the first amendment has been primarily confined to the last fifty years").

4. As used by the Court, commercial speech is an imprecise term. The problems arising from the current loose use of that term are examined in Section II(A), infra. For present purposes, commercial speech is defined as "speech proposing a commercial transaction ...." Central Hudson Gas \& Elec. Corp. v. Public Serv. Comm'n, 447 U.S. 557, 562 (1980).

5. The Court's original decision excluding commercial speech from first amendment protection was Valentine v. Chrestensen, 316 U.S. 52 (1942). Although several subsequent cases eroded Valentine's holding, commercial speech as such first received express first amendment protection in Virginia State Bd. of Pharmacy v. Virginia Citizens Consumer Council, Inc., 425 U.S. 748 (1976).

6. For example, the Court alternatively has emphasized the interests of listeners in making "intelligent and well informed" economic choices, Virginia Board, 425 U.S. at 765 , and the government's interest in decreasing popular demand for a legal activity the government nevertheless wished to discourage. See Posadas de Puerto Rico Assocs. v. Tourism Co., 478 U.S. 328, 342, 348 (1986) (restrictions on advertisements for legal gambling facilities do not violate the first amendment).

7. Compare Bolger v. Youngs Drug Prod. Corp., 463 U.S. 60, 68 (1983) (unsolicited directmail pamphlet describing the risks of venereal disease and the advantages of condoms in preventing venereal disease constituted commercial speech where the pamphlet mentioned a specific brand of condom) with In re Primus, 436 U.S. 412, 431 (1978) (letter from ACLU attorney offering to represent recipient not commercial speech).

8. The test originally was set forth in Central Hudson, 444 U.S. 557, and consists of four parts. So long as advertising (1) is not false or misleading (in which case it may be suppressed) the Court must examine: (2) whether the regulation advances a substantial governmental interest; (3) whether the limitation directly advances the asserted governmental interest; and (4) whether the limitation is no more restrictive than is necessary to achieve the asserted governmental interest. Id. at 564. While the test appears straightforward, courts have applied it inconsistently. See Schauer, Commercial Speech and the Architecture of the First Amendment, 56 U. CIN. L. Rev. 1181, 1182 (1988) [heremafter Schauer, Architecture]. Morcover, the Court largely ignored and then eliminated the fourth part of the test altogether. See infra text accompanying notes 137-39. 
ning of the process, and is given almost no respect as speech per se. ${ }^{9}$ Indeed, as Professor Schauer recently noted "almost all of the foundational questions about first amendment protection for commercial speech remain on the table for consideration and reconsideration." 10

This Comment examines some of these foundational questions, and explores the ramifications their answers could have for the commercial speech doctrine. Specifically, the Comment argues the first amendment seeks, at least in part, to foster rationality and self-realization on the part of recipients of speech. The Comment then argues that the Court has erred by focusing upon the topics it perceives to be commercial speech, and upon the profit motive of commercial speakers, rather than analyzing commercial speech in liglit of these first amendment values. The Comment concludes that when such an analysis is performed, most of what we now call commercial speech should receive full first amendment protection. ${ }^{11}$

The Comment first reviews the evolution of the commercial speech doctrine, looking critically at the Court's reasoning and support for the doctrine's foundational principles. It then examines why we care about protecting speecli at all, and what the answers to this question tell us about commercial speecl. The Comment then exammes potential objections to the conclusions reached in the first three Parts.

\section{The Evolution of the Commercial Speech Doctrine}

\section{A. The Rise and Fall of the Commercial Speech Exception}

Cominercial speecli mitially received first amendment consideration in Valentine v. Chrestensen. ${ }^{12}$ In Valentine, an entrepreneur attempted to distribute a flyer advertising his submarine tour attraction. On one side of the flyer was an advertisement for the tour, on the otlier a protest of

9. See infra Section IV(B).

10. Schauer, Architecture, supra note 8, at 1182; see also, Barrett, "The Uncharted Area"Commercial Speech and the First Amendment, 13 U.C. DAVIS L. REv. 175, 207-08 (1980) ("[f]ew issues [concerning commercial speech] are settled and a wide range of uncertainties exist[s]. . . The difficulty may be that the Court, despite its language to the contrary, is not applying the first amendment to commercial speech."). Professor Schauer wrote prior to the Court's holding in Board of Trustees v. Fox, 109 S. Ct. 3028 (1989). Nevertheless, while Professor Schauer might agree with the result in Fox, the case did not remedy the doctrinal confusion that plagues commercial speech. Additionally, to the extent the doctrinal modifications announced in Fox clarified this area of speech, they did so only by resort to a very regressive view of speech.

11. Currently, commercial speech receives "a limited form of First Amendment protection." Posadas de Puerto Rico Assocs. v. Tourism Co., 478 U.S. 328, 340 (1986); see also Fox, 109 S. Ct. at 3033.

12. 316 U.S. 52 (1942). Prior to Valentine, the Court had made passing references to what later would be called commercial speech in Schneider v. State, 308 U.S. 147 (1939). See infra text accompanying notes $176-80$. 
certain New York City policies. ${ }^{13}$ The police department reviewed this flyer and determined that it violated a statute prohibiting distribution of advertising flyers. Chrestensen was advised lie could distribute only the side of the fiyer containing the protest. ${ }^{14}$

Chrestensen sued the city to enjoin it from restraining distribution of the two-sided fiyer. He obtained relief froin the district and appellate courts. The appellate court was particularly troubled by the city's suggestion that it could restrain the distribution of the fiyer because the flyer's primary purpose was commercial. ${ }^{15}$ The court also was concerned by the prospect of the police reviewing flyers like Chrestensen's to determime whether they fell within the ambit of the statute. ${ }^{16}$

The Supreme Court, lowever, found neither consideration troubling. In an opinion Justice Douglas later condemned as "casual" and "almost offhand," 17 the Court reversed. Even though without precedent, the Court was "clear that the Constitution inposes no sucl restraint on government as respects purely commercial advertising." 18 The Court made no mention of the prospect of police censorship.

By holding that "tlie affixing of the protest against official conduct to the advertising circular was with the intent, and for the purpose, of evading the prohibition of the ordinance," 19 the Court imphicitly endorsed the primary purpose test rejected by the appellate court. The primary purpose analysis was, of course, siniply a rough way to identify commercial speech. The Court offered no explanation for its conclusion that such speecli enjoys no first amendment protection, a conclusion that lacked even the balancing logic of the primary purpose test.

The Court solidified the primary purpose test for identifying coinmercial speech in Breard v. Alexandria, ${ }^{20}$ where it upheld a local ordinance prohibiting unsolicited door-to-door sales of magazine

13. Valentine, 316 U.S. at 53.

14. Id. Thus, the first case to address the issue presented the Court with the most intractable type of commercial speech: a communication that contains substantive comment on matters of noncommercial public interest together with statements the Court believes are merely commercial speecl. This problem of "mixed speecll" lias troubled the Court to this day, and is the basis for much of the doctrinal confusion in this area. The problem is explored more fully in Part II, infra.

15. Chrestensen v. Valentine, 122 F.2d 511, 515 (2d. Cir. 1941), rev'd, 316 U.S. 52 (1942). The court perceived its problem as follows: "How mucl is primarily? 'Primarily commercial' presunuably signifies a test quantitative in amount; a limited dross of commercialism does not vitiate, though a more substantial amount may, and presuniably will." Id. (emphasis in original).

16. The court stated: "In net result the police officers administering the regulation are to be arbiters ... of tle quantum of advertising as against protest and the purpose of tlie citizen in speaking and writing." Id. (emphasis in original).

17. Cammarano v. United States, 358 U.S. 498, 514 (1959) (Douglas, J., concurring).

18. Valentine v. Chrestensen, 316 U.S. 52, 54 (1942).

19. Id. at 55 .

20. 341 U.S. 622 (1951). 
subscriptions. ${ }^{21}$ Both the majority and dissent distinguished the case from earlier cases striking down regulations as applied to religious organizations. ${ }^{22}$ The primary purpose test, however, did not last long, at least not in its strong form. In New York Times Co. v. Sullivan, ${ }^{23}$ the Court was required to analyze an advertisement that did not fit precisely into a strict conceptualization of the primary purpose test. At issue in $\mathrm{New}$ York Times was an advertisement that described the pitched battle of the civil rights movement in the Soutl. The advertisement concluded by seeking funds to support the movement and the defense of Dr. Martin Luther King, $\mathrm{Jr}^{24}$

The Court seemed to shift from a primary purpose analysis of the advertiseinent to a content-based analysis, holding:

The publication here was not a "commercial advertisement" in the sense in which the word was used in Chrestensen. It communicated information, expressed opinion, recited grievances, protested claimed abuses, and sought financial support on behalf of a movement whose existence and objectives are matters of the highest public interest and concern. ${ }^{25}$

The Court then expressly disavowed any role for economic motivation in its analysis, noting "[t]hat the Times was paid for publishing the advertisement is as immaterial in this connection as is the fact that newspapers and books are sold." 26

Nevertheless, New York Times only partially abandoned the primary purpose test for identifying commercial speech. While the advertisement at issue solicited funds as openly as an advertisement for an ordinary product, the money served political ends, rather than merely financial ones. The Court's reference to the irrelevance of the Times' profit motive must be seen in this light. When the problem of "pure" speech mixed with speech soliciting money for profit has arisen in subsequent cases, the Court has denied full first amendment protection to the

21. Id. at 641-45.

22. Id. at 645; see, e.g., Martin v. Struthers, 319 U.S. 141 (1943). The majority believed that nagazine sales, while not depriving the magazines of first amendment protection, "brings into the transaction a commercial feature." Breard, 341 U.S. at 642. Justice Black dissented on first amendment grounds, but would have upheld the statute as applied to the door-to-door pot inerchant. Id. at $650 \mathrm{n}$.*.

23. 376 U.S. 254 (1964). The Court had earher determined that speech made for a profit was not therefore deprived of first amendment protection. Joseph Burstyn, Inc. v. Wilson, 343 U.S. 495, 501-02 (1952) ("That books, newspapers, and nagazines are published and sold for a profit does not prevent them from being a form of expression whose hiberty is safeguarded by the First Amendment. We fail to see why operation for profit should have any different effect im the case of motion pictures."). New York Times extended this notion to the advertisimg forn.

24. Id. at 256-57.

25. Id. at 266. The list of factors the Court beheved distinguished the advertisement in $\mathrm{New}$ York Times from the flyer in Valentine is significant, because speech with similar characteristics since has been denominated "cominercial speech." See, e.g., Bolger v. Youngs Drug Prod. Corp., 463 U.S. 60 (1983) and infra Section II(A).

26. New York Times, 376 U.S. at 266. 
speech. $^{27}$

\section{The Erosion of Valentine}

Having substantially modified the test's definitional power, the Court simply ignored the primary purpose test for several years. In the meantime, the Court decided several cases that undercut Valentine's exclusion of commercial speech froin the protection of the first amendment. In Pittsburgh Press Co. v. Pittsburgh Commission on Human Relations, ${ }^{28}$ the Court addressed a charge that a newspaper's genderbased listing of employment advertiseinents violated a statute prohibiting gender classifications.

The Court reaffirmed that speech was not excepted froin first amendment protection merely because it took the form of an advertiseinent or was motivated by profit. ${ }^{29}$ The Court also refined the doctrine somewhat when it noted in passing that advertisements for illegal goods or services would receive no first amendment protection. ${ }^{30}$

Two years later in Bigelow v. Virginia, ${ }^{31}$ the Court further eroded Valentine, reading that decision as merely upholding "a reasonable regulation of the manner in which commercial advertising could be distrib. uted."32 The Court reaffirmed Pittsburgh Press' holding that neither an advertising form nor a profit motive would deprive speech of first amendinent protection. ${ }^{33}$ Additionally, the Court engaged in a probing content analysis, finding that an advertisenent informing Virginians that legal abortions were available in New York "contained factual inaterial of clear 'public interest.' ... [and involved] the exercise of the freedom of communicating information and dissemmating opinion."34

The Court then posited a balancing test in which the coininercial nature of the speech would be one factor to weigh in determining whether a governmental interest justified a regulation. Noting that " $[t] \mathrm{he}$ relationship of speech to the marketplace of products or of services does not make it valueless in the inarketplace of ideas," the Court struck

27. See, e.g., Board of Trustees v. Fox, 109 S. Ct. 3028, 3036 (1989) ("[t]hese examples consist of speech for a profit, they do not consist of speech that proposes a commercial transaction... . Some of our most valued forms of protected speech are uttered for a profit." (citing New York Times, 376 U.S. 254 (1964) (emphasis in original))). Admittedly, the speech at issue in Fox did not rise to the level of public concern implicated by the speech in New York Times.

28. 413 U.S. 376 (1973).

29. Id. at $384-85$.

30. Id. at 388 ("We have no doubt that a newspaper constitutionally could be forbidden to publish a want ad proposing a sale of narcotics or soliciting prostitutes.").

31. 421 U.S. 809 (1975).

32. Id. at 819 (emphasis added).

33. Id. at 819-20.

34. Id. at 822 . 
down the Virginia regulation. ${ }^{35}$

Bigelow was an unusual case because the service advertised, abor-, tion, recently had been afforded constitutional protection as one method ' of exercising the right to privacy. This led the Court in later cases ${ }^{36}$ to conclude that the constitutional status of the subject of commercial speech should play a role in determining the protection the speech receives. Nevertheless, while the status of a woman's right to an abortion, and the debate on that issue, played a role in the Court's analysis of the importance of the speech, the Court did not explicitly argue that the protected status of abortion rights somehow imbued the advertisennent with greater constitutional status. ${ }^{37}$

Significantly, this holding was the first departure from the primary purpose test in a case where the speech was, on its face, purely commercial. In Bigelow the Court for the first time treated a for-profit advertisement as genuine speech, entitled to first ainendment consideration on its own inerits, rather than disposing of it by reference to Valentine. The decision therefore set the stage for first ainendinent protection of all coinmercial speech, including mixed speech.

\section{The Rise of First Amendment Protection: Virginia Board}

Having thus laid the foundation, the Court overruled Valentine and provided express first amendment protection for commercial speech in Virginia State Board of Pharmacy v. Virginia Citizens Consumer Council, Inc..$^{38}$ In Virginia Board, a consumer group challenged a Virginia statute prohibiting price advertising by pharmacists. ${ }^{39}$ The Court did not atteinpt to find some noncommercial content of public importance in the speech the consuiner group wished to receive, as it had in Bigelow..$^{40}$ Rather, the Court inet the issue head-on and held that "speech which does 'no inore than propose a commercial transaction' " was entitled to soine first amendinent protection. ${ }^{41}$

Virginia Board promised expansive first ainendment protection for

35. Id. at 826 .

36. See infra text accompanying notes 298-307, and infra Section III(B)(1). Some commentators also have drawn this conclusion. See, eg., Note, First Amendment Protection for Commercial Advertising: The New Constitutional Doctrine, 44 U. CHI. L. REv. 205, 235-36 (1976) [hereinafter Note, New Constitutional Doctrine].

37. See infra Section III(B)(1).

38. 425 U.S. 748 (1976).

39. Id. at 753 .

40. Indeed, this distinguished Virginia Board from Bigelow. In the Court's words, "The 'idea' [the pharmacist] wishes to communicate is simply this: 'I will sell you the $\mathrm{X}$ prescription drug at the Y price." Virginia Board, 425 U.S. at 761.

41. Id. at 762 (quoting Pittsburgh Press v. Pittsburgh Comm'n on Human Relations, 414 U.S. 376,385 (1973)). 
commercial speech. That promise has gone largely unfulfilled. ${ }^{42}$ Nevertheless, the Court's opimion contains several insights critical to a thorough analysis of the commercial speech doctrine. First, the Court recognized that potential recipients of such speech have a substantial "listener interest" that is served by giving first amendment protection to commercial speech. ${ }^{43}$

Second, the Court discarded the Valentine Court's concern that advertisers would "dress up" their advertisenents by including nominal statements upon matters of public interest. ${ }^{44}$ Instead, the Court effectively concluded that the purely commercial portion of the speech was entitled to some first amendment protection, even without the addition of more traditional social or political speech. The Court held that "[o]ur pharmacist, for example, could cast himself as a commentator on storeto-store disparities in drug prices, giving his own and those of a competitor as proof. We see little point in requiring him to do so, and little difference if he does not." 45

Third, the Court argued that commercial speech was inseparable froin categories of speech, such as social and poitical cominentary, that traditionally have received full first amendment protection. ${ }^{46}$ The Court found commercial speecls to have value both as an integral coinponent of

42. See infra Part IV.

43. In the Court's words, "As to the particular consumer's interest in the free flow of commercial information, that interest may be as keen, if not keener by far, than his interest in the day's most urgent political debate." 425 U.S. at 763; see also Note, Constitutional Protection of Commercial Speech, 82 CoLUM. L. REV. 720, $733-34$ (1982) (recognizing commercial speech serves listener interests while arguing such interests are narrower than "speaker interests") [hereinafter Note, Constitutional Protection]. Indeed, a large part of the problem in subsequent commercial speech cases is that the Court frequently justifies restrictions on commercial speech by reference to assertedly mimimal speaker interests, ignoring the foundation of the doctrine in listener interests. See, e.g., Friedman v. Rogers, 440 U.S. 1 (1979).

44. 425 U.S. at 764-65.

45. Id.

46. The Court stated:

So long as we preserve a predominantly free enterprise economy, the allocation of our resources in large measure will be made through numerous private economic decisions. It is a matter of public interest that those decisions, in the aggregate, be intelligent and well informed. To this end, the free flow of commercial information is indispensable. ... And if it is indispensable to the proper allocation of resources in a free enterprise system, it is also indispensable to the forination of intelligent opinions as to how that system ought to be regulated or altered. Therefore, even if the First Amendment were thought to be primarily an instrument to enlighten public decisionmaking in a democracy, we could not say that the free flow of information does not serve that goal.

Id. at 765 (citations omitted). This statement prompted then-Justice Rehnquist, in dissent, to argue that the Court was returning to economic due process under the guise of the first amendment. See id. at 784. At least two commentators agree with Rehnquist. See Jackson \& Jeffries, Commercial Speech: Economic Due Process and the First Amendment, 65 VA. L. REV. 1, 30 (1979). This view is critiqued in section IV(C), infra. The Court's economic analysis, however, was not necessary to its conclusion that the first amendment extended protection to "commercial speech." See Virginia Board, 425 U.S. at 775-81 (Stewart, J., concurring) (" "[f]reedom of discussion, if it would fulfill its historic function in this nation, must embrace all issues about which infornation is needed or appro- 
these traditionally protected types of speech, and as a catalyst for debate subsequently conducted on political or social grounds. ${ }^{47}$

Fourth, the Court scrutinized closely the interests that the state claimed justified the regulation, tlough the Court did not give a name to the level of scrutiny it apphed. ${ }^{48}$ Specifically, the state argued that the advertising ban fostered the integrity and high professional standards of pharmaceutical professionals. ${ }^{49}$ The Court rejected such arguments, concluding that "[ $[\mathrm{t}] \mathrm{he}$ strength of these proffered justifications is greatly undermined by the fact that high professional standards, to a substantial extent, are guaranteed by the close regulation to which pharmacists in Virginia are subject." 50 The Court therefore found the Virginia statute too broad for its asserted purpose. On a related point, the Court also noted that the state's interest could be better served by more, rather than less, speech: "if [channels of communication] are truly open, nothing prevents the 'professional' pharmacist from marketing his own assertedly superior product, and contrasting it with that of the low-cost, high volunie prescription drug retailer." 51

Finally, the Court held that the Virginia legislature's greater power to regulate pharmacists did not include the lesser power to achieve such regulation through prohibitions on speech, arguing that "Virginia is free to require whatever professional standards it wishes of its pharmacists . . . . But it may not do so by keeping the public in ignorance of the entirely lawful terms that competing pharmacists are offering." 52

In its now (relatively) famous footnote twenty-four, the Court also made two arguinents that have shaped the subsequent development of the commercial speech doctrime: that false commercial speech has no value and deserves no constitutional protection, and that punishing such speech does not chill other, valuable speech. The Court relied upon its holding in Gertz v. Robert Welch, Inc. ${ }^{53}$ that "there is no constitutional value in false statements of fact" 54 to justify regulations against sucl1 advertising on a theoretical level.

The Court further souglit to ensure its reference to Gertz did not graft onto commercial speech the defamation principle that some false speech must be tolerated to avoid chilling "speech that matters." The

priate to enable the members of society to cope with the exigencies of their period'"). Id. at 775 (quoting Thornhill v. Alabama, 310 U.S. 88, 102 (1940)).

47. Virginia Board, 425 U.S. at 765.

48. Id. at 768 .

49. Id.

50. Id.

51. Id. at 770 .

52. Id.

53. 418 U.S. 323 (1974).

54. Id. at 340 .

55. Id. at 341 . The defamation principle originated in New York Times Co. v. Sullivan, 376 
Court sought to distinguish commercial speech from the type of speech contemplated by the defamation holdings im two ways. First, the Court argued that strict enforcement of accuracy requirements would not chill commercial speech because advertisers generally have better access to the information necessary to verify their stateinents than do media defendants. Second, because commercial speech was a key to profits, commercial enterprises would advertise regardless of the potential for suffering sanctions under overbroad regulations. ${ }^{56}$

The first argument is, at best, partially correct, and then only in certain limited cases. The Court's argument, however, certainly does not apply to all commercial speech; indeed, the argument is entirely irrelevant to perhaps the most common form of commercial speech-that which is not truth-evaluative at all. ${ }^{57}$ The second argument is not really a proposition of law at all. Rather, it is an empirical prediction, and an incorrect prediction at that. It has muddied subsequent efforts to regulate false or misleadimg advertising severely. ${ }^{58}$.

After Virginia Board, the Court appeared ready to extend full first amendment protection to commercial speech. ${ }^{59}$ In quick succession, the Court struck down prohibitions upon placing "for sale" or "sold" sigus in front of houses ${ }^{60}$ and upon advertiseinents for contraceptives. ${ }^{61}$ Thus, the Court extended unprecedented protection to commercial speech. As

U.S. 254 (1964) ("A rule compelling the critic of official conduct to guarantee the truth of all his factual assertions-and to do so on pain of libel judgments virtually unlimited in amount-leads to a comparable 'self-censorship." "). Id. at 279.

56. As the Court put it:

The truth of commercial speech, for example, may be more easily verifiable by its disseminator than, let us say, news reporting or political commentary, in that ordinarily the advertiser seeks to disseminate information about a specific product or service that he himself provides and presumably knows more about than anyone else. Also, commercial speech may be more durable than other kinds. Since advertising is the sine qua non of commercial profits, there is little likelihood of it being chilled by proper regulation and foregone entirely.

Attributes such as these .. may make it less necessary to tolerate inaccurate statements for fear of silencing the speaker.

Id. at 772 n.24.

57. See infra text accompanying notes 310-21.

58. See infra Part IV. At a mininum, the Court's reliance upon the profit motive of commercial advertisers to justify a stringent standard of aceuracy modified the Court's prior statements asserting that the profit motive was irrelevant in commercial speeclı analysis. See, e.g., Pittsburgl Press Co. v. Pittsburgl Comm'n on Human Relations, 413 U.S. 376, 385 (1973) ("If a newspaper's profit motive were determinative, all aspects of its operations . . . would be subject to regulation. . . . Such a basis for regulation clearly would be incompatible witl the First Amendment."). Additionally, the Court's reliance upon the profit motive necessarily cast doubt upon the Court's rejection of the primary purpose test.

59. "Full first amendment protection" is used lere to describe the level of scrutiny the Court applies to speech it considers at or near tle "core" of the first amendment-sucl as political speech, or cultural or artistic speech. Currently, restrictions on such speech are subject to strict scrutiny.

60. Linmark Assocs. v. Township of Willingboro, 431 U.S. 85, 87 (1977).

61. Carey v. Population Servs. Int'l, 431 U.S. 678, 700-02 (1977). 
the implications of extending full first amendment protection to commercial speech became clear, liowever, the Court began to restrict the protection offered by Virginia Board.

\section{B. The Nascent Rebirth of the Valentine Exception}

In Bates v. State Bar, ${ }^{62}$ the Court struck down Arizona's blanket prohibition agaimst lawyer advertising. Nevertheless, the Court expressly backed away from according full first amendinent protection to commercial speech, refusing to apply the first amendment overbreadth doctrine to overturn the state's advertising ban. ${ }^{63}$ To support its conclusion, the Court relied upon Virginia Board's contention that commercial speech is relatively more durable than other types of speech, supposedly rendering it less susceptible to the chilling effect of overbroad regulations that underlies the overbreadtl doctrine. ${ }^{64}$ The Court also emphasized dicta from Virginia Board that 'there are 'commonsense differences' between commercial speech and other varieties."65 These differences, unarticulated almost by definition, subsequently have supported a great many restrictions of commercial speech.

The Court continued its retreat from according full first amendment protection to commercial speech in Ohralik v. Ohio State Bar

62. 433 U.S. 350,384 (1977).

63. The overbreadth doctrine is not, technically speaking, a first amendment doctrine at all; it is an exception to the usual standing requirement that a plaintiff must have suffered a cognizable injury herself and cannot litigate the claims of another. The justification for the doctrine, however, has first amendinent roots. Under the overbreadth doctrine, plaintiffs "are permitted to cliallenge a statute not because their own rights of freedoin of expression are violated, but because of a judicial prediction or assumption that the statute's very existence may cause others not before the Court to refrain from constitutionally protected speecl or expression." Broadrick v. Oklahoina, 413 U.S. 601,612 (1973).

Thus, the overbreadth doctrine is designed "not primarily for the benefit of the hitigant, but for the benefit of society-to prevent the statute from chilling the First Amendinent riglits of otlier parties not before the court." Secretary of State of Maryland v. Joseph H. Munson Co., 467 U.S. 947, 958 (1984). The doctrine "reflects the conclusion that the possible harm to society from allowing unprotected speecli to go unpunished is outweighed by the possibility that protected speech will be inuted." Bates, 433 U.S. at 350 .

64. Bates, 433 U.S. at 381.

65. Id. at 380-81 (quoting Virginia Board, 425 U.S. at 771 n.24). Justice Stewart sought to elaborate upon these "commonsense differences" in lis concurrence:

Ideological expression ... is integraliy related to the exposition of thouglit-thouglit that may shape our concepts of the whole universe of man. Although such expression may convey factual information relevant to social and individual decisionmaking, it is protected by the Constitution ... even if it includes inaccurate assertions of fact. . . .

Coinunercial price and product advertising differs markedly from ideological expression because it is confined to proinotion of specific goods or services. The First Ainendinent protects the advertisement because of the "infornation of potential interest and value" conveyed rather than because of any direct contribution to the intercliange of ideas.

Virginia Board, 425 U.S. at 779-80 (quoting Bigelow v. Virginia, 421 U.S. 809, 822 (1975), other citation and footnotes ounitted). This conclusion is contested in Section $\operatorname{III(B)(2),~infra.~}$ 
Association. ${ }^{66}$ The most important development in Ohralik was the Court's adoption of a "leveling" rationale to justify extending a lesser degree of first amendment protection for commercial speech than the Court gave speech it beheved was at the core of the first amendinent. The Court succinctly stated the rationale:

To require a parity of constitutional protection for commercial and noncommercial speech alike could invite dilution, simply by a leveling process, of the force of the Amendinent's guarantee with respect to the latter kind of speech. Rather than subject the First Amendment to such a devitalization, we instead have afforded commercial speech a limited measure of protection, commensurate with its subordinate position in the scale of First Amendment values .... 67

The Court went on to uphold a state regulation agamst in-person solicitation by lawyers. ${ }^{68}$

A proper understanding of Ohralik and its role in commercial speech doctrine requires an appreciation of the unique circunistances of the case. Ohralik was an attorney who sohcited chents in ways that Justice Marshall terned "classic examples of 'ambulance chasing." "69 $\mathrm{He}$ was disciplined, and sought to defend against the disciplinary charges by claiming, in part, that his conduct was partially inforinational and, therefore, protected under Bates. ${ }^{70}$ The Court rejected this contention, adopting the leveling rationale. ${ }^{71}$ The opinion suggests, however, that the holding was limited to the umique circuinstances of the case. As Justice Marshall put it, "[w] hat is objectionable about Ohralik's behavior here is not so inuch that he solicited business for limiself, but rather the circuinstances in which he performed that solicitation and the ineans by which he accoinplished it."

66. 436 U.S. 447,456 (1978).

67. Id. at 456. Professor Schauer has expressed sympathy for this rationale. See Schauer, Architecture, supra note 8, at 1182.

68. Ohralik, 436 U.S. at 457. The Court distinguished Bates by arguing that in-person solicitation poses different risks than does normal advertising, such as the risk of the soliciting attorney obtaining chent consent under duress. Id.

69. Justice Marshall, concurring, detailed Ohralik's actions as follows:

Ohralik, an experienced lawyer in practice for over 25 years, approached two 18-year old women shortly after they had been in a traumatic car accident. One was in traction in a hospital rooin; the other had just been released following nearly two weeks of hospital care. Both were in pain and may have been on medication; neither had more than a high school education.

Id. at 469 (Marshall, J., concurring).

70. Id. at 455 .

71. Id. at $455-56$.

72. Id. at $\mathbf{4 7 0}$ (Marshall, J., concurring). Justice Marshall concluded: "[T]he Court's actual holding . . . is a limited one: that the solicitation of business, under circumstances ... presenting substantial dangers of harm to society or the client independent of the solicitation itself, inay constitutionally be prohibited by the State." Id. (eunphasis added). Indeed, the inajority opinion indicated inuch the same conclusion by citing, immediately after its statement of the leveling rationale, authority to the effect that "it has never been deeuned an abridgement of freedom of 
In these circumstances, the Court's reference to the leveling effect of affording protection to Ohralik's activity is understandable, but the factor that would have caused such leveling appears to be a course of conduct that included speech, not speech per se. Such a course of conduct should be regulated by balancing the governmental interest implicated by the course of conduct against the speech values, if any, implicated. ${ }^{73}$

The problem with Ohralik is that the Court failed to incorporate into its analysis the distinction between speech and conduct that entails speech. If, as Justice Marshall seeined to indicate, Ohralik defrauded the aceident victims, or subjected thein to duress, the Court's speech discussion was entirely superfuous; it had no more need to discuss the first amendinent than it would in reviewing a conviction for solicitation to commit inurder. It is no wonder the Court was worried about the effect on the first amendment of extending first amendment protection to Ohralik's speech. Unfortunately, the Court's indiscriminate use of the leveling rationale allowed it to avoid the more difficult problein of justifying its treatunent of commercial speech by reference to first amendment theory. ${ }^{74}$

Ohralik, with its leveling rationale and subordination of commercial speech in what the Court perceived as the first amendment value hierarchy, set the stage for Central Hudson Gas \& Electric Corp. v. Public Service Commission. ${ }^{75}$ In Central Hudson, the Court confronted the efforts of the Public Service Commission of New York to prevent a utility froin sending its customers advertisements promoting the use of electricity. The Court struck down the prohibition as overbroad in relation to the asserted state interests. ${ }^{76}$ The Court's analysis drastically restructured the commercial speech doctrine.

First, the Court failed to define what it ineant by commercial speech, referring to such speech alternatively as "expression related solely to the econoumic interests of the speaker" and "speech proposing a coinmercial transaction."77 Second, the Court refused to extend full first amendment protection to advertising that included claims related to social or political issues, concluding that only direct commentary on

speech or press to make a course of conduct illegal merely because the conduct was in part initiated, evidenced, or carried out by means of language, either spoken, written, or printed." Id. at 456 (quoting Gibboney v. Empire Storage \& Ice Co., 336 U.S. 490, 502 (1949)).

73. See, e.g., City of Los Angeles v. Preferred Conımunications, Inc., 476 U.S. 488, 495 (1986) ("where speech and conduct are joined in a single course of action, the First Amendment values must be balanced against competing societal interests").

74. See infra Section IV(C).

75. 447 U.S. 557 (1980).

76. Id. at 570-71.

77. Id. at 561-62. 
such issues would receive full protection. ${ }^{78}$

The Court reasoned that because utility companies enjoyed full first aniendment protection for speecll directly addressing social or political problems, there was no need to grant their commercial speecli such protection simply because it mcluded noncommercial commentary. As the Court put it, " $[t]$ here is no reason for providing similar constitutional protection when such stateinents are made only in the context of commercial transactions." 79 In this regard, the Court retreated from an issue expressly decided in Virginia Board. ${ }^{80}$

Most significantly, the Court set forth a four-part test to determine whether a regulation of commercial speech is constitutional. ${ }^{81}$ This action was significant both for the nature of the test itself and because the Court's creation of the test implicitly admitted that states could regulate even some truthful commercial speech. ${ }^{82}$

Under the test, a court must ask whether the commercial speech at issue relates to a lawful activity and is not misleading. The court then must ask if the asserted governmental imterest is substantial. If the answer to these questions is yes, the court must determine wlietlier the regulation directly advances the asserted governmental interest and whether it is no more extensive than necessary to serve that interest. ${ }^{83}$ The Court claimed this test liad "developed" from earlier commercial speech cases. ${ }^{84}$ The Court referred, lowever, to no authority establishing any one of the elements, much less all four. Rather, the Court appears to lave crafted the test from whole cloth. ${ }^{85}$ The same could be said for the Court's treatment of mixed political commentary and commercial speech.

Significantly, the Court rejected Justice Blackmun's argument that the Public Service Commission liad impermissibly attempted to control consumers' economic clioices by limiting their access to the utility's speecli. ${ }^{86}$ Justice Blackmun's argument invoked lis conclusion in Virginia Board that the greater power to regulate economic activity did not include the lesser power to regulate that activity tlirough limitations upon speech. ${ }^{87}$ Indeed, the inajority's four-part test could upliold exer-

78. Id. at 563 n.5 (citing Consolidated Edison Co. v. Public Serv. Comm'n, 447 U.S. 530 (1980)).

79. Id.

80. See supra note 45.

81. Central Hudson, 447 U.S. at 566.

82. See Note, Constitutional Protection, supra note 43, at 729.

83. Central Hudson, 447 U.S. at 566.

84. Id.

85. See id. at 573 (Blackmun, J., concurring).

86. Id. at 573-76 (Blackmun, J., concurring).

87. See supra text accompanying note 52 . 
cises of such lesser power based upon assertions of the greater power. ${ }^{88}$ The Court subsequently has approved this tactic. ${ }^{89}$

The Court also rejected Justice Blackmun's effort to minimize the impact of the Court's distinction between cominercial and noncominercial speech. Specifically, Justice Blackmun argued the "common sense differences" between commercial and noncommercial speech justified regulations only of false, misleading, or coercive cominercial speech. ${ }^{90}$ He concluded "[n]o differences between commercial speech and other protected speech justify suppression of commercial speech in order to influence public conduct through manipulation of the availability of information." 91

Finally, then-Justice Rehnquist dissented, reiterating his Virginia Board argument that regulation of cominercial speech should be considered economic regulation, rather than regulation of speech. Thus, for Justice Rehnquist, "by labehing economic regulations of busmess conduct as a restraimt on 'free speech' [the Court has] gone far to resurrect the discredited doctrime of [economic due process]."92

\section{The Return of the Valentime Exception: From Bolger to Fox}

The definitional problems raised by the Court's loose use of the term

88. Central Hudson, 447 U.S. at 573-76 (Blackmun, J., concurring). Specifically, Justice Blackmun argued that the four-part test was inappropriate where "a State seeks to suppress information about a product in order to manipulate a private economic decision that the State cannot or has not regulated or outlawed directly." Id. at 573. He concluded:

I seriously doubt whether suppression of information concerning the availabihty and price of a legally offered product is ever a permissible way for the state to "dampen" demand for or use of the product. Even though "commercial" speech is mvolved, such a regulatory measure strikes at the heart of the First Amendment . . . because it is a covert attempt by the state to mamipulate the choices of its citizens, not by persuasion or direct regulation, but by depriving the public of the information needed to make a free choice. . . . [T] he State's policy choices are insulated from the visibility and scrutiny that direct regulation would entail and the conduct of the citizens is molded by the information that government chooses to give them.

Id. at 574-75. Thus, Justice Blackmun believed that the regulation violated the first amendment because "[i]f the first amendment guarantee means anything, it means that, absent clear and present danger, government has no power to restrict expression because of the effect its message is likely to have on the public." Id. at 575 .

Justice Stevens concurred in this conclusion. Id. at 581 (Stevens, J., concurring). Citing Justice Brandeis' famous concurrence in Whitney v. Califormia, 274 U.S. 357, 376-77 (1927), he argued:

[T]ruthful communication may persuade some citizens to consume more electricity than they otherwise would. I assume that such a consequence would be undesirable and that government may therefore prohibit and punish the unnecessary or excessive use of electricity. But if the perceived harm associated with greater electrical usage is not sufficiently serious to justify direet regulation, surely it does not justify the kind of clear and present danger that can justify the suppression of speech.

Central Hudson, 447 U.S. at 581.

89. See infra Section IV(B), and text accompanying notes 102-05.

90. 447 U.S. at 578 (Blackmun, J., concurring).

91. Id.

92. Id. at 591 (Rehnquist, J., dissenting). 
commercial speech in Central Hudson came home to roost in Bolger $v$. Youngs Drug Product Corp. ${ }^{93}$ Bolger considered the first amendment status of unsolicited, direct-mail pamphlets that discussed the dangers of venereal disease and the benefits of condoms in counteracting those dangers. At the end of the pamphlet, a specific brand of condom was mentioned. ${ }^{94}$

The Court concluded that the pamphlet constituted commercial speech. The Court admitted the pamphlet could not be deemed commercial speech solely because it was an advertisement, nor solely because it referred to a specific brand name, nor solely because it was motivated by a desire for profit. Nevertheless, without explaining the theoretical basis for its conclusion, the Court found that the convergence of all three factors rendered the pamphlet commercial speech. ${ }^{95}$ To support its holding, the Court adopted the Central Hudson alternative means of expression rationale that, because a commercial entity could comment directly upon matters of public imterest and concern, it therefore need not receive full first amendment protection when it seeks to combine such commentary with a commercial message. ${ }^{96}$

Therefore, despite Virginia Board's apparent holding to the contrary, ${ }^{97}$ speech that combimed a commercial message with a statement on an issue of general social importance once again was labeled commercial speech. Although the outcome was different, ${ }^{98}$ the definitional result was the same in Bolger as in Valentine. ${ }^{99}$ The definitional determination in cases after Bolger has been tremendously important, because the Court

93. 463 U.S. 60 (1983).

94. Id. at $66 \mathrm{n} .13$.

95. Id. at 66-67.

96. In the Court's words "[a] company has the full panoply of protections available to its direct comments on public issues, so there is no reason for providing similar constitutional protection when such statements are made in the context of commercial transactions." Id. at 68. The Court followed this general proposition by noting that "[a]dvertisers should not be permitted to immunize false or misleading product information from government regulation simply by including references to public issues." Id. This reference was superfluous for, as the Court later acknowledged, Young's speech was neither false nor misleading. Id. at 69.

97. See supra text accompanying note 45. While Virginia Board did not hold that mixed speech was not commercial speech, it did hold that even commercial speech unadorned by speech on political or social issues deserved first amendment protection. To the extent inixed speech after Bolger was treated as commercial in order to reduce the level of first amendment protection it otherwise would receive, that treatment is inconsistent with Virginia Board, as is Bolger.

98. The Court held "advertising for contraceptives not ouly implieates " substantial individual and social interests"' in the free fiow of commercial information, but also relates to activity which is protected from unwarranted state interference." Bolger, 463 U.S. at 69 (quoting Carey v. Population Servs. Int'l, 431 U.S. 678, 700-01 (1977) (quoting Virginia State Bd. of Pharmacy v. Virginia Citizens Consumer Council, Inc., 425 U.S. 748, 760, $763-66$ (1976))). Therefore, the Court held Young's speech was entitled to first amendment protection. This aspect of Bolger is discussed in Section $\operatorname{III}(\mathrm{B})(1)$, infra.

99. See supra text accompanying note 19. 
subjects speech deened commercial to the unique doctrines that have grown up around commercial speech, and it uses these doctrines to uphold regulations on other types of speech.

Bolger was followed by Posadas de Puerto Rico Associates v. Tourism Co. ${ }^{100}$ In Posadas, the Court faced a Puerto Rican statute that forbade advertising of casino gambling, which was legal in Puerto Rico, aimed at Puerto Rican nationals. On its face, Posadas purported to apply the Central Hudson four-part test for regulation of commercial speech. The Court, however, treated the asserted state interests with such deference that its conclusion has been deeined "irreconcilable" with Central Hudson. ${ }^{101}$

More importantly, the Court einbraced fully the notion that "the greater power to coinpletely ban casino gainbling necessarily includes the lesser power to ban advertising of casino gambling." 102 The Court expressly rejected the argument that "having chosen to legalize gambling ... the legislature is prohibited by the First Amendment from using restrictions on advertising to accomplish its goal of reducing demand for such gambling." ${ }^{103}$ The Court thus extended Central Hudson ${ }^{104}$ and expressly rejected one of the main rationales for Virginia Board. ${ }^{105}$

The Court asserted that this result was correct because "[i]t would ... be a strange constitutional doctrine which would concede to the legislature the authority to totally ban a product or activity, but deny to the legislature the authority to forbid the stimulation of demand for the product or activity through advertising." 106 Thus, not only did the Court approve the restrictions on gambling advertisements at issue in the case, it announced a doctrine that implicitly approves restrictions on similar advertisements for products such as alcohol and tobacco, ${ }^{107}$ if not for restrictions upon speech pertaining to anything a legislature could ban.

Interestingly, the rhetoric of these decisions is similar to that of the Court's equal protection decisions. For example, the Court referred to

100. 478 U.S. 328 (1986).

101. See Schauer, Architecture, supra note 8, at 1182.

102. Posadas, 478 U.S. at $345-46$.

103. Id. at 346.

104. See supra text accompanying note 79.

105. See supra text accompanying notes $49-50$.

106. 478 U.S. at 346.

107. The Court's citation to lower court cases upholding restrictions on such advertisements bolsters this conclusion. See Posadas, 478 U.S. at 343-46. The lower court cases include Dunagin v. City of Oxford, Miss., 718 F.2d 738, 751 (5th Cir. 1983) (en banc) (alcohol advertisennents), cert. denied, 467 U.S. 1259 (1984); Oklahoma Telecasters Ass'n v. Crisp, 699 F.2d 490, 501 (10th Cir. 1983) (alcohol advertisements), rev'd. on other grounds sub nom. Capital Cities Cable, Inc., v. Crisp, 467 U.S. 691 (1984); Capital Broadcasting Co. v. Mitchell, 333 F. Supp. 582, 585 (D.D.C. 1971) (cigarette advertisements), aff'd. sub nom. Capital Broadcasting Co. v. Acting Attorney Gen., 405 U.S. 1000 (1972). 
the latter two elements of the Central Hudson test as "basically involv[ing] a consideration of the 'fit' between the legislature's ends and the means chosen to accomplish those ends." 108 Indeed, the Court used its analysis of this fit to dispose of Posadas' equal protection claim, noting "appellant can fare no better under the equal protection guarantee of the Constitution. If there is a sufficient 'fit' between the legislature's means and ends to satisfy the concerns of the First Amendment, the same 'fit' is surely adequate under the applicable . . . equal protection analysis." 109 Because the Court found the relevant fit to be sufficiently close, it saw no constitutional violation in the statute.

Justice Brennan dissented, objecting primarily to Puerto Rico's efforts to control its citizens' behavior through the mechanism of advertismg regulations. Echoing Justice Blackmun's concurrence in Central Hudson, 110 he argued that there is "no reason why cominercial speech should be afforded less protection than other types of speech where ... the government seeks to suppress commercial speech in order to deprive consumers of accurate information concerning lawful activity."111 Reasoning that "no differences between commercial and other kinds of speech justify protecting commercial speech less extensively where, as here, the government seeks to manipulate private behavior by depriving citizens of truthful information concernimg lawful activities," 112 Justice Brennan argued that the statute was unconstitutional.

Posadas struck at the very foundation of support for commercial speech within the first ainendment. The greater power/lesser power rationale rests upon an assumption that commercial speech has little or no value as speech per se. ${ }^{113}$ The rationale assumes cominercial speech actually is merely one form of commercial activity, and thus subject to regulation by reference to the traditional power of the state to regulate commercial activity. ${ }^{114}$

\section{Posadas' immediate intellectual heir, San Francisco Arts \& Athletics,}

108. Posadas, 478 U.S. at 341 . In equal protection cases, courts must inquire into the fit between the asserted purposes of a statute and the statute's structure in an effort to weed out pretextual motives and discern the true purpose of a statute. The conclusion derived from this imquiry then must be compared to the benchmark equal protection requirement that "those who are similarly situated be similarly treated." Tussman and tenBroek, The Equal Protection of the Laws, 37 CAL1F. L. REv. 341, 344 (1949). Whether a law passes muster under this test depends upon how closely a court requires the structure of the statute to fit its asserted purposes, a standard that is itself derived from the nature of the class affected by the statute.

109. Posadas, 478 U.S. at 344 n.9 (citation omitted).

110. See supra text accompanying notes 86-87.

111. Posadas, 478 U.S. at 350 (Brennan, J., dissentimg).

112. Id. at 351 .

113. This argument is developed more fully in Section IV(B), infra.

114. Not surprisingly, Justice Rehnquist, the author of Posadas, first advanced the conception of commercial speech as merely a form of commercial activity imcidentally involving speech in his dissent im Virginia State Bd. of Pharmacy v. Virginia Citizens Consumer Council, Inc., 425 U.S. 748, 
Inc., v. United States Olympic Committee, ${ }^{115}$ bolsters this conclusion. There, the Court addressed a challenge by the USOC to the use of the word "Olympic" to promote the "Gay Olympic Games," an athletic event resembling the traditional Olympic Games but limited to homosexual participants. ${ }^{116}$ By statute, ${ }^{117}$ the USOC possesses the right to limit certain uses of the word "Olympic," a right that potentially infringes upon the first amendment rights of others who seek to use the word.

In the context at issue, the Court found the statute applied primarily to commercial speech, ${ }^{118}$ specifically SFA\&A's efforts to sell various items emblazoned with the phrase "Gay Olympic Games."119 The Court also found that the asserted governmental interest-rewarding and encouraging the USOC's efforts to promote the United States Olympic Team-easily justified the regulation of commercial speech. ${ }^{120}$

By concludimg that the statute apphed primarily to commercial speech the Court avoided the overbreadth analysis otherwise warranted by SFA\&A's contention that the statute affected a significant amount of noncommercial speech. ${ }^{121}$ The Court's treatment of the speech as commercial was particularly significant in this context because it used that label im conjunction with, and as a partial justification for, its assertion that the statute restricted only the manner in which SFA\&A could present its message, and not the message itself. ${ }^{122}$

In dissent, Justice Brennan focused primarily upon these conclusions, arguing that the statute applied to a substantial amount of noncommercial speech and, therefore, was overbroad. ${ }^{123}$ Additionally, Justice Brennan argued that the Court's contention that the statute restricted only the manner in which SFA\&A presented its speecli was wrong, and that as applied to SFA\&A the statute violated the first amendment principle of content neutrality. ${ }^{124}$

781-84, 787-89 (1976), and repeated it in his dissent in Central Hudson Gas \& Elec. Corp. v. Public Serv. Comm'n, 447 U.S. 557, 584, 588-600 (1980).

115. 483 U.S. 522 (1987).

116. Id. at 525 .

117. The specific provision is section 110 of the Amateur Sports Act of 1978, Pub. L. No. $95-$ 606, 92 Stat. 3045, (codified at 36 U.S.C. $\$ 380$ (1988)). See San Francisco Arts \& Athletics, 483 U.S. at 526.

118. San Francisco Arts \& Athletics, 483 U.S. at 536 n.15.

119. Id. at 539 .

120. Id. at $537-39,537$ n.16.

121. Id. at 536 n. 15 .

122. Id. at 536 .

123. Id. 561 (Brennan, J., dissenting).

124. Id. Specifically, Justice Brennan relied upon Cohen v. California, 403 U.S. 15 (1971), for the proposition tliat "[w]e cannot indulge the facile assumption that one can forbid particular words without also running a substantial risk of suppressing ideas in the process." San Francisco Arts \& Athletics, 483 U.S. at 569 (Brennan, J., dissenting) (quoting Cohen, 403 U.S. at 26). That proposition was applied to SFA\&A's inessage by Judge Kozinski in his dissent from the Court of Appeals' deinal 
San Francisco Arts \& Athletics is a curious case that demonstrates two very important things about the commercial speech doctrine. First, as Justice Brennan and Judge Kozinski argued, the case actually had very little to do with commercial speech. ${ }^{125}$ But the Court invoked the label of commercial speech, and the assorted doctrines that have grown up around it, to avoid consideration of the more serious first amendment issues implicated by the statute. In this sense, the case is heir to Ohralik in that it used the commercial speech label to minimize the impact of the decision on first amendment doctrine as a whole. ${ }^{126}$

Second, by giving relatively short shrift to SFA\&A's speech, the case furtlier ensconced Posadas' vision of commercial speech as a subset of commercial activity that happens to involve some speech elements. Thus, in the aftermath of San Francisco Arts \& Athletics the protection offered by the commercial speech doctrine was significantly weaker than it had been under Virginia Board. Indeed, the state of the doctrine resembled Valentine almost as much as it did Virginia Board.

This doctrinal regression was substantially furthered, if not made complete, by Board of Trustees v. Fox. ${ }^{127}$ Fox is primarily notable for two holdings. First, the Court attempted to define commercial speech more precisely, with potentially significant effects on the doctrine and the first amendment as a whole. Second, the Court held that the fourth element of the Central Hudson test, that regulation of commercial speech should be no more extensive than necessary to serve the governmental interest justifying the regulation, does not require a state to adopt the least restrictive regulation possible to effectuate its goals. ${ }^{128}$

Fox addressed a regulation excluding from university dormitories essentially all speech activity motivated by profit. ${ }^{129}$ At issue was the effort of a company that sold lousewares to hold what the Court terned

of rehearing in the case: "[t]he ideas embodied in the word Olympic can, of course, be expressed by other ineans, but only in a much clumsier fashion, without the same nuance of meaning." International Olympic Comm. v. San Francisco Arts \& Athletics, Inc., 789 F.2d 1319, 1321 (9th Cir. 1986). Justice Brennan, like Judge Kozinski, compared SFA\&A's message to Cohen's and concluded that 'just as a jacket reading 'I Strongly Resent the Draft' would not have conveyed Cohen's inessage, so a title such as 'The Best and Most Accomplished Amateur Gay Athletics Competition would not serve as an adequate translation of petitioners' inessage." San Francisco Arts \& Athletics, 483 U.S. at 569 (citing 789 F.2d at 1321).

125. See infra Section IV(B).

126. See also infra Section II(B).

127. 109 S. Ct. 3028 (1989).

128. Id. at 3032-33.

129. The regulation provided as follows:

No authorization will be given to private commercial enterprises to operate on the State Umiversity campuses or in facilities furnished by the University other than to provide for food, legal beverages, campus bookstore, vending, linen supply, laundry, dry cleaning, banking, barber and beautician services and cultural events.

Id. at 3030. The University interpreted the regulation as prohibiting any invited speech "where the end result is the intent to make a profit by the invitee." Id. at 3036. 
"Tupperware parties" in the dormitories. ${ }^{130}$ At these events, the company would offer certain housewares for sale and provide information on topics "such as how to be financially responsible and how to run an efficient home." 131

The respondents ${ }^{132}$ contended that the commercial aspects of the speech were "inextricably intertwined" with the noncommercial aspects and, therefore, the speech as a whole was noncommercial. ${ }^{133}$ The Court rejected this contention, and in doing so atteinpted to resolve the "mixed speech" problem once and for all. The Court held:

[T]here is nothing whatever "inextricable" about the noncommercial aspects of these presentations. No law of man or of nature makes it impossible to sell housewares without teaching home economics .... Nothing in the Resolution prevents the speaker from conveying, or the audience from hearing, these noncommercial messages, and nothing in the nature of things requires them to be combined with commercial messages.

Includimg these home economics elements no more converted [the company's] presentations into educational speech, than opening sales presentations with a prayer or a Pledge of Allegiance would convert them into rehigious or political speech. ${ }^{134}$

Therefore, the Court concluded that a rule banning the coinpany's entire presentation should be judged under the more lenient standards applica-

130. Id. at 3030-31.

131. Id. at 3031.

132. The suit originally was brought by university students, and joined by the company. The company dropped out of the litigation after trial in the district court. Thus, only the students contested the regulation before the Court. Id. at 3030. This turn of events mooted the district court's time, place, and manner analysis, because no speaker brought a claim to the court of appeals. Because the district court decided the case on speaker-based grounds, the factual determinations necessary to resolve histener-based questions were not made, thus necessitating the renuand.

133. Id. at 3031. For this assertion, the respondents relied upon Riley v. National Fed'n of the Blind, Inc., 487 U.S. 781 (1988). There, the Court addressed a statute that, in relevant part, required organizations that solicited funds for charities to disclose to potential contributors the percentage of donations retained by the organization during the preceding 12-month period. Id. at 795 . The Court in Riley held:

[W] do not beheve that the speech retains its commercial character when it is inextricably intertwined with otherwise fully protected speech. Our lodestars in deciding what level of scrutiny to apply to a compelled statement must be the nature of the speech taken as a whole . . . . [w] here, as here, the component parts of a single speech are inextricably intertwined, we cannot parcel out the speech, applying one test to one phrase and another test to another phrase. ... Therefore, we apply our test for fully protected expression. Id. at 796 (citations and footnote omitted).

The Fox Court found this holding distinguishable because the commercial speech in Riley was inextricably intertwined with noncommercial speech by operation of the statute requiring disclosure, rather than by the choice of the speaker. Fox, $109 \mathrm{~S}$. Ct. at 3031.

134. Fox, $109 \mathrm{~s}$. Ct. at 3031-32. Not surprisingly, the Court's citation for this assertion vas to Bolger and the Central Hudson admonition that "advertising which "inks a product to a current public debate' is not thereby entitled to the constitutional protection afforded noncommercial speech." Id. at 3032 (quoting Central Hudson Gas \& Elec. Corp. v. Public Serv. Comm'n, 447 U.S. 557, 563 n.5 (1980)). The Court did not refer to the discussion of this issue in Virginia Board. 
ble to regulations of commercial speech. ${ }^{135}$

This holding strongly reaffirmed the approach taken in Valentine and Bolger, with an invocation of Central Hudson to soften the blow. To the question whether noncommercial elements in speech give the speech as a whole full first amendment protection, or whether commercial speech elements deprive the noncommercial elements of protection they otherwise would enjoy, the Court firmly embraced the latter answer. To the natural follow-up question over the fate of the noncommercial elements, the Court imphicitly answered by reference to alternative means of expression. While this aspect of the holding in Fox did not itself reduce the level of protection afforded cominercial speech, it potentially increases substantially the range of speech that can be considered commercial. $^{136}$

The second holding in Fox construed the fourth element of the Central Hudson test so as not to require that regulations of commercial speech be the least restrictive means to achieve the asserted goal of the regulation in order to pass constitutional muster. ${ }^{137}$ Instead, the Court adopted Posadas' formula and held that the fourth element of the test requires merely a reasonable fit between the structure of the regulation and the asserted purpose of the statute. ${ }^{138}$

This holding did not further restrict the level of protection afforded commercial speech; Posadas had made it reasonably clear that the Court would not apply a least restrictive means analysis to regulations of commercial speech: Fox simply reaffirmed that fact and linked it specifically to the Central Hudson test. ${ }^{139}$ Thus, the Central Hudson test now officially sanctions a looser fit between a statute's structure and its asserted purpose than would be allowed under a least restrictive means standard.

In the aftermath of Fox several issues regarding commercial speech remain unsettled. First, the Court has failed to articulate a coherent definition of commercial speech, thus allowing too broad a range of speech to be deemed commercial. Second, several exceptions to standard first ainendment practice have arisen around the doctrine, with little or no justification. Finally, and most importantly, while the Court has concluded commercial speech is entitled to only intermediate-level first amendment protection, it has failed to develop a consistent rationale supporting this conclusion, and the rationales it has used have not under-

135. Id. at 3032-33.

136. See infra Section II(B).

137. Fox, 109 S. Ct. at 3035.

138. Id.

139. The Posadas Court expressly rejected one less restrictive alternative, a counterspeech policy. 478 U.S. at 344. Additionally, Justice Brennan listed numerous less restrictive alternatives in his dissent, a list the Court obviously did not embrace. Id. at 356-57 (Brennan, J., dissenting). 
gone critical analysis sufficient to demonstrate the strength of their support.

Taken together, these problems call for significant changes in the commercial speech doctrine. The balance of this Comment is devoted to isolatimg the areas in need of change and proposing an alternative approach to the commercial speech problem.

\section{II \\ ARCHITECTURAL IMPLICATIONS OF THE CURRENT DOCTRINE}

In commenting upon the arguments regarding the level of first amendment protection that should be afforded commercial speech, Professor Schauer has adinonished us to take into account the effect that our treatment of the commercial speech doctrine has upon the first aniendinent as a whole. As he puts it, "[r]ules are not hermetically sealed from each other, but nitertwine and overlap, and abut."140

Thus, he concludes, "[i]nsofar as the makers of legal rules ignore consequences other than the most doctrinally local effect of a putative rule, the design of rules is defective, taking into account only soine rather than all of the consequences of choosing this rule rather than that one."141 For Professor Schauer, such an analysis is crucial to informed discussion of the commercial speech doctrime, especially because of the unique nature of the first amendinent. ${ }^{142}$

This Section examines critically sone of the implications for the first amendnient as a whole of the commercial speech doctrine as presently constructed. ${ }^{143}$ It exammes the Court's efforts to define commercial speech and then builds upon that definitional analysis to demonstrate the dangers posed by the current doctrine. The Section nakes two arguinents: first, that commercial speech has not been defined

140. Schauer, Architecture, supra note 8, at 1181.

141. Id.

142. Id. at 1181-82. According to Professor Schauer, such an analysis is important in first amendment cases in part "because various different first amendment rules he especially close to each other. Or perhaps it is because the counterintuitive nature of much first amendment protection makes the entire building more fragile, and proper architecture consequently more pressing." Id.

143. This Part uses "architecture" in a broader sense than Professor Schauer used the term in his article, and I do not intend this section to satisfy the precise analysis Professor Schauer calls for. In particular, Professor Schauer assumed commercial speech properly could be identified as a category, and he examined the implications for the rest of the first amendment of different ways of treating that category. Id. at 1182-85.

This Part argues, among other things, that commercial speech as presently defined by the Court does not constitute a separate category of speech at all. Based upon this analysis, Part V, infra, questions whether categorizing speech by topic is the right way to go about inaking categories. I use the term "architecture" here because iny primary concern is not on problems within the commercial speech doctrine, but on the affect those problems have on the rest of the first amendment. 
adequately and, second, that some of the elements that make up the commercial speech doctrine are ill-conceived and apphed far too broadly because of the inadequate definition of commercial speech.

\section{A. The Problem of Defining Commercial Speech}

Because commercial speech currently is treated very differently than other types of speech, the first and perhaps most important problem to resolve is what speech will receive such different treatment? ${ }^{144}$ Put simply, how do we know commercial speech when we see it? This effort is crucially important to understanding and refining the commercial speech doctrine because the Court's definitional view is bound up with its substantive view of commercial speech.

The Court's most recent effort to define commercial speech, as noted above, imvolves two inquiries. First, the Court asks whether the speech "propose[s] a commercial transaction." 145 If so, at least in a case involving mixed speech, the Court now apparently will seek to determine whether the speech that "propose[s] a commercial transaction" is "the principal type of expression at issue."146 These two questions in turn implicate a number of very thorny issues. I will atteinpt to parse out these issues by examining in detail the Court's efforts to define commercial speech, and by coinparing the result of these efforts to the results in another line of cases-tliose involving solicitations for charitable organizations.

The argument arising out of this analysis is twofold. First, as presently construed there is no principled distinction, either in the cases or in the values implicated by the first amendment, between commercial speech and other, similar speech that enjoys full first amendinent protection. Rather, the Court's definition rests upon an imphicit inistrust of

144. As Professor Farber puts it, "[i]f special rules are to govern commercial speech, the immediate practical problems are to define commercial speech, thereby determining the applicability of these rules, and to establish just how these rules differ from the rules applicable to noncominercial speech." Farber, Commercial Speech and First Amendment Theory, 74 Nw. U.L. REv. 372, 376 (1979).

145. Board of Trustees v. Fox, $109 \mathrm{~S}$. Ct. 3028, 3031 (1989) (citation omitted). On its face, the definition is obviously circular: speech is commercial when it proposes a transaction that is commercial. Although defining "commercial" as a term of art is not intrinsically difficult, it becomes difficult when some of the recurring themes of the definitional problem, such as unixed speech and the profit motive, are introduced. Indeed, both in the abstract and as used by the Court, "commercial" seems closely linked to, if not synonymous with, profits. The problem of defining commercial speech, however, is not that simple, and approaches that either implicitly or explicitly make it so should be rejected. See infra text accompanying notes 201-07.

146. Fox, $109 \mathrm{~S}$. Ct. at 3031 . Given the definitional result in Bolger and the cases discussed below, I doubt that the Court seriously intended to create a new level of definitional analysis by this phrase. Rather, it more likely restates Valentine's primary purpose test, referring to the motive of the speaker rather than the varying quantities of commercial and noncommercial speech in a single unit of communication. 
speech that leads in some fairly proximate way to a commercial transaction. ${ }^{147}$

Unfortunately, the Court's various descriptions of the definition do not reveal this concern, forcing the lower courts to guess at the proper way to categorize speech in any given case. Largely because of this situation, the doctrine sweeps far too inuch speech under the label "commercial speech," depriving a wide variety of speech of the full first amendment protection that it deserves.

\section{The Court's Definitional Efforts}

The most notable aspect of the Court's definitional sorties has been the looseness with which the Court has treated language defining commercial speech. Thus, for example, when the Court extended first amendment protection to commercial speech in Virginia Board, it asked whether "speech which does no more than propose a commercial transaction" was protected by the first amendment. ${ }^{148}$ Yet by Central Hudson the Court had dropped the "does no more" language and joined what remained with language referring to "the economic interests of the speaker." 149

It is not overly pedantic to say that there is a very large difference

147. This argument is not entirely novel. At least one commentator has asserted that the profit motive plays a role in defining commercial speech. See Note, Constitutional Protection, supra note 43 , at 720 n.2 ("Two ingredients must at a minimum be present [for commercial speech to exist] ... the speech must tend to promote the purchasing of goods or services . . . [and] the purpose of the speech must be the advancement of the financial interests of the speaker via that transaction."). The definition, however, does little more than assert the role of profit, and does not explore the implications of allowing profit to play a role in defining commercial speech. The Court's repeated disavowal of profit motivation as a factor in defining commercial speech, see infra note 175 and accompanying text, justifies a more extensive analysis.

Professor Shiffrin also has noted the apparent role that profit motivation plays in understanding commercial speech, but his observations are more directed toward explaining the nature of what the Court terms the "common sense" distimction between commercial speech and other types of speech. See Shiffrin, The First Amendment and Economic Regulation: Away From a General Theory of the First Amendment, 78 Nw. U. L. REv. 1212, 1257-58, 1265 (1983).

Finally, one of the earliest commercial speech commentators imcorporated a profit motive as part of a definition of commercial speech. See Note, New Constitutional Doctrine, supra note 36, at 234-35. That definition, however, incorporated the profit element so that speakers who addressed topics pertaining to specific goods or services would not automatically be classified as commercial speakers. Id. While this is certainly an important element to consider in fashioning a definition, it can be accomplished better and more easily without reference to the profit motive. See infra notes 224-30 and accompanying text.

148. See Virginia State Bd. of Pharmacy v. Virginia Citizens Consumer Council, Inc., 425 U.S. 748, 762 (1976) (emphasis added). I am using the phrase "protected" here in the sense of the distinction Professor Schauer draws between the coverage of the first amendment and the protection offered to covered activity. See Schauer, Categories and the First Amendment: A Play in Three Acts, 34 V AND. L. REV. 265, 270 (1981) (explaining that speech may implicate first amendment concerns without receiving first amendment protection) [hereinafter Schauer, Categories].

149. Central Hudson Gas \& Elec. Corp v. Public Serv. Comm'n, 447 U.S. 557, 561 (1980). The problem is so acute that the Court in Fox cited Virginia Board for the Central Hudson version of the 
between speech that proposes a commercial transaction and speech that does nothing else, and an enormous difference between the latter and speech merely relating to the speaker's economic interests. It is, however, hardly novel to note the Court's imprecision in this area, ${ }^{150}$ and that imprecision, by itself, tells us very little about the Court's commercial speech doctrime. Nevertheless, the Court's imprecision does suggest that the specifics of a given instance of speech, whether the words used do or do not do something more than propose a commercial transaction, may be less important to the Court than some other factor. The question then becomes: what does the Court look for that, when found, turns speech into commercial speech?

An important piece of the answer to this question can be gleaned from three recent mixed speech cases that considered definitional questions: Bolger, Fox, and Zauderer. ${ }^{151}$ Bolger involved three pamphlets discussing venereal disease, one of which was described by the Court as "an eight-page pamphlet discussing at length the problem of venereal disease and the use and advantages of condoms im aiding the prevention of venereal disease." 152

The commercial eleinent was introduced because the drug store was identified "at the bottom of the last page of the pamphlet, which states that the pamphlet has been contributed as a public service by [the drug store], the distributor of Trojan-brand prophylactics." ${ }^{153}$ The Court conceded that the pamphlets could not "be characterized merely as proposals to engage in commercial transactions." 154 Nevertheless, the Court found that because the pamphlets were admittedly advertisenents, referred to a specific product, and were issued to make a profit, they were commercial speech. ${ }^{155}$

Of these factors, only the profit element appears genuinely to have affected the Court's view of the speech. New York Times had established that the advertising form did not automatically signal the presence of commercial speech, as the Bolger Court acknowledged. ${ }^{156}$ And political

commercial transaction definition, the version abandoning the "does no more" language. Fox, $109 \mathrm{~S}$. Ct. at 3031.

150. See Schauer, Architecture, supra note 8, at 1185 n.17.

151. Bolger v. Youngs Drug Prod. Corp., 463 U.S. 60 (1983); Board of Trustees v. Fox, 109 S. Ct. 3028 (1989); Zauderer v. Office of Disciplinary Counsel, 471 U.S. 626 (1985).

152. Bolger, 463 U.S. at 63 n.4.

153. Id.

154. Id. at 67 . The Court also referred to "core" commercial speech, raising the possibility of subdividing the category of commercial speech, itself the newest subdivision of the first amendment, into a "core" and a "periphery." This possibility has not materialized.

155. Id. at 66-67. The Court provided no theoretical justification explaining why three otherwise insufficient factors possessed sufficient synergistic power to render the pamphlet commercial speech.

156. Id. at 66. Indeed, the Court cited New York Times in noting that the advertising form was 
advertisements presumably are not affected in the least (at least not as a definitional matter) by the form in which they are presented.

Indeed, the Court's analysis made far too much of the admission that the pamphlets were advertisements; in form and content they resembled public health tracts more than advertisements. Moreover, the only role the specification of the product played was to facilitate the profit interest of the drug store-to make sure that those persuaded by the pamphlet would purchase the identified product at the indicated drug store, rather than some other product somewhere else.

Similarly, in Fox the Court simply used the presence of the speech soliciting the purchase of household goods to define the speech concerning home economics as commercial speech. Citing, predictably, to Bolger, the Court concluded that "[i]ncludimg these home economics elements no more converted [tle] presentations into educational speech, than opening sales presentations with a prayer or a Pledge of Allegiance would convert them into religious or political speech."157 The passage from Bolger (actually itself citing Central Hudson) was to the same effect. ${ }^{158}$

Fox demonstrates more clearly than any otler case that the Court's definition of commercial speech actually turns upon the profit motive (or lack thereof) of the speaker. The regulation at issue in Fox reaclied all speech that was imtended to earn a profit for the speaker. ${ }^{159}$ Thus, the regulation "would prohibit tutoring, legal advice and medical consultation provided (for a fee) in students' dormitory rooms."160 The Court found it necessary to distinguish such speech, to which it desired to grant full first amendment protection, from commercial speech. Therefore, the Court held that "[w]hile these examples consist of speech for a profit, they do not consist of speech that proposes a commercial transaction,

itself irrelevant, though that form contributed to the Court's determination that the pamphlets were commercial speech.

157. Fox, 109 S. Ct. at 3032. Justice Scalia's sales meeting example from Fox demonstrates that the Court's analysis in these cases actually takes place on a subtextual continuum: as the cases below will show, the Court would not view the presence of some commercial speech elements at a meeting it otherwise viewed as political or religious as depriving that meeting of full first amendment protection.

The converse is true in the commercial speech cases. Although the Court has not provided clues as to how far in either direction speech must go to be characterized as commercial or noncommercial, the discussion below indicates the factor mcasured by the continuum is the speaker's degrce of profit motivation.

158. The quote from Bolger was: "We have made clear that advertising which links a product to a current public debate' is not thereby entitled to the constitutional protection afforded noncommercial speech." Bolger, 463 U.S. at 68 (quoting Central Hudson, 447 U.S. at 563 n.5)).

159. Fox, $109 \mathrm{~S}$. Ct. at 3036 . The regulation reached "any invited speech where the end result [was] the intent to make a profit." Id. (citation omitted).

160. Id. 
which is what defines commercial speech."161

This, however, appears to be a distinction without a difference, especially in terms of the relative first amendment value of the speech involved. Simply put, there is no apparent reason (and none articulated by the Court in Fox) that speech proposing a commercial transaction is less valuable or should be protected less than speech made to consuminate the transaction. Indeed, at one level it seeins to be putting the cart before the horse to say that speech inade pursuant to or in satisfaction of a commercial transaction is inore important than speech that informs a consumer whether she can afford the transaction in the first place. This is all the inore coinpelling given the Court's belief that commercial speech in general, and in Fox in particular, primarily implicates histener interests.

Additionally, the distinction proposed in Fox, if applied strictly, would lead to exceedingly curious results. For example, take the Court's hypothetical attorney advising a student in the dormitory, using fully protected speech. ${ }^{162}$ If while advising her chent the attorney recognizes that the client has a legal problem apart froin the matter for which he retained her, what should she do? Under the reasoning in Fox she would be required to leave the dormitory, establish terms of representation for the second inatter, and ouly then return to the dormitory to continue advising the student. Would the result in either case be different if she did not seek to represent the chent in the second matter but only recommended a colleague? What if she received a referral fee? These exannples may appear extreme, but they follow directly froin the Court's distinction.

Worse, the distinction clearly does not lie in the content of the speech. As noted above, the speech at issue in Fox included a discussion of home econormics as well as a solicitation to purchase products. By analogy, the speech of an attorney whose solicitations were intermingled with advice would be classified as commercial, as would the coinparable speech of the Court's hypothetical doctor and tutor. ${ }^{163}$ Conversely, the lawyer, doctor, or tutor could babble incoherently with full first amendment protection so long as she did not propose a commercial transaction. The Court could only guess at the nature of such speech-it would have

161. Id. (emphasis im original). This statement, of course, reflects only the Court's guess as to the real nature of the speech imvolved, and assnmes a sharp dichotomy between speech for a profit and speech proposing a profit-based relationship. Such a dichotomy would be difficult to apply; more importantly, it has no basis in first amendment theory.

162. $I d$.

163. See id. This phenomenon is discussed in greater detail in Section III, infra. One wonders why the speech pertaining to home economics issues was not considered fully protected speech given to make a profit. 
no way of knowing the first amendment value of the speech other than by definitional assumption.

Finally, also as noted above, the distinction cannot turn upon the interest of the histeners. At least the students who inamtained the lawsuit presumably desired to hear the speech, and their desire inakes sense, given the logical priority afforded speech informing the students whether they could afford a transaction.

Because neither the content nor the value of the speech does not motivate the distinction, we must determine what does. As in Bolger, the answer appears to be the profit motive. This assertion seems surprising, especially because the Court purports to distinguish between two types of profit-motivated speech-speech asking for money and speech earning it. Nevertheless, although there is hittle express evidence within the opinion, ${ }^{164}$ the Court's implicit analysis appears to run soinething like this: speakers are more concerned with consummating a transaction, with profit per se, when proposing a transaction than they are when speaking to satisfy their obligations under the transactional agreement. Thus, the Court views the proposal stage as a kind of flash point of profit notivation, which must be open to greater regulation to guard against the dangers that the Court perceives to inhere in profit-seeking. ${ }^{165}$

Contrary to the apparent plain meaning of its definition, however, the Court does not limit its definition of commercial speech simply to commercial proposals, as Bolger ainply deinonstrates. And even if the Court did limit its definition only to commercial proposals its definitional analysis still would be unsatisfactory, because not all proposals are alike. This latter point nay be demonstrated by reference to some basic contract principles governing advertiseinents. All first year law students (and perhaps no one else) know that not all advertisements constitute enforceable offers, inany are only invitations to purchase. ${ }^{166}$ Advertisements constitute offers only when they are sufficiently definite and tend to impose soine obligation upon prospective purchasers (such as an item for sale to the first ten custoiners).

Such advertisements are in fact contractual offers and are simply not part of the frecdom of speech contenplated by the first amendment. Thus, regulation of such advertisements, hike regulation of solicitations to

164. The evidence from within the opinion is sinuply the analytical process of elimination set out above. The arguments in the balance of this Section, however, also tend to support this interpretation of Fox.

165. One important aspect of the proposal stage as a flash point of profit motivation is that the Court's opinions about the role of profit in commercial speech are most heavily concentrated there. Thus, for example, the Court's views regarding the durability and verifiability of commercial speech are most applicable at the proposal stage because those views are actually based on the profit motive of the speaker.

166. L. Fuller \& M. Eisenberg, Basic Contract Law 352-62 (4th ed. 1981). 
murder or price fixing, poses no first amendment problem. ${ }^{167}$ In each case the speech constitutes essentially a verbal act, which may be regulated to prevent any deleterious effects arising from that act. This is not to say that the first amendment protection of commercial speech depends upon how such speech would be treated by contract, though the Court. has made similar errors. ${ }^{168}$ Rather, reference to contract principles merely helps identify the different ways advertisements may affect histeners-by merely inviting an offer or creating an obligation to sell.

Indecd, if one conceives of what is now called commercial speech as existing on a continuum ranging from verbal acts to speech of social importance incidentally involving a product (such as in Bolger) it is clear that a definition of commercial speech should exclude invitations to deal. A definition, such as the Court's current working definition, that incorporates such speech and gives it only intermediate first amendment protection is hopelessly overbroad in terms of first amendment theory. The reasons for limiting protection for commercial speech, to the extent they are valid at all, simply do not apply to speech such as in Bolger.

Second, the Court's perception of the proposal stage of a commercial transaction as a flash point of profit motivation simply reflects the Court's somewhat skeptical view of the commercial world. More importantly, neither the Court's opinions nor the first amendment justify acting upon this view to allow more extensive state regulation of speech. In essence, because the Court believes that fraud and abuse are more likely to occur at the proposal stage of a commercial transaction, it allows the government to place prophylactic regulations on the speech used at that stage. The Court makes such speech vuhrerable to regulation by defining it to be commercial. The Court then uses the definition of coininercial speech to invoke an intermediate level of scrutiny, and a concomitant intermediate level of first amendment protection. Under such scrutiny, the Court will tolerate the looser fit between means and ends inherent in prophylactic measures.

It should be evident from this discussion that the Court's view, and its treatinent of the defimitional question, suggests that the Court is at least partially conflating verbal acts, which inay be regulated freely by fraud statutes, etc., with inere invitations to deal, and is conflating both types of speech with pure speech-such as the speech in Bolger. Because invitations to deal look and feel somewhat like verbal acts, the Court is

167. The speech in Ohralik appeared to be an incidental part of a course of conduct posing a risk of fraud and/or the infliction of duress upon the accident victims. See supra text accompanying notes 69-73. As the Court's implicit focus on contractual notions for deflnitional purposes skews its deflmition, the Court's focus on the course of conduct in Ohralik led it to articulate a rationale, the leveling rationale, properly applicable to such a course of conduct, but to remarkably little else.

168. See infra notes 389-91. 
unwilling completely to stay the free hand with which the government regulates contracts. Unfortunately, because the Court fails to take notice of important differences between verbal acts, invitations to deal, and pure speech such as in Bolger this partial conflation swallows up an enormous amount of speech that should receive full first amendment protection.

The Court's conclusion, that speech at the proposal stage must be open to regulation, simply does not follow from any of its premises, which is to say that profit is logically irrelevant to the level of protection to which speech is entitled. That argument is developed later. ${ }^{169}$ For present purposes, the important point is that, paradoxical though it may seem, the Court's concern for regulating profit-seeking behavior determined the definitional result in Fox.

Finally, Zauderer confirms and inakes exphicit that the profit inotive is the key to the definitional reasoning underlying the other two cases. Zauderer involved an advertisement that informed readers of allegations of adverse health effects caused by the Dalkon Shield contraceptive, and named Zauderer as an attorney who represented several plaintiffs in such cases, and who was willing to take on further cases on a contingent-fee basis. ${ }^{170}$ As Justice White indicated, "[a]ppellant's advertising contains statements regarding the legal rights of persons . . . that, in another context, would be fully protected speech. That this is so does not alter the status of the advertisement as commercial speech . ..."171 But what is it about the portion of the advertisement naming the lawyer and outlining his proposed terms of einployinent that inakes the whole advertiseinent commercial speech and deprives otherwise "fully protected speech" of its protection?

The solicitation portion of the advertisement presumably neither obfuscated the "fully protected" portion" ${ }^{172}$ nor posed an affirmative threat, since the Court found the advertisement neither false nor mislead-

169. See infra Part III.

170. Zauderer v. Office of Disciplinary Counsel, 471 U.S. 626, 630-31 (1985). Additionally, the attorney placed an advertisement indicating that he was willing to represent persons accused of drunk driving on a contingent fee basis. Id. at 629-30. The Court sustained a public reprimand issued against the attorney on the ground that the advertisement was misleading because it failed to disclose possible plea-bargained resolutions, under which a chent might be hable for fees. Id. at 634, 655.

171. Id. at 637 n.7.

172. I ain here using obfuscate to refer to the possibility that the solicitation portion of the advertisement might somehow interfere with the communicative effect of the portion of the advertisement discussing the potential health risks arising from the use of the Dalkon Shield. I assume the solicitation did not obfuscate the health-related portion of the advertisement both because there is no referencc to such an effect in the Court's opinion and because, as a pragmatic matter, the likelihood that the solicitation portion of the advertisement would be acted upon (by woinen retaining Zauderer) logically depended in large part upon the clarity and force of the healthrelated speech. 
ing. ${ }^{173}$ Indeed, even with the solicitation, the advertisennent tended "to acquaint persons with their legal rights who might otherwise be shut off from effective access to the legal system." 174 The solicitation portion of the advertisement only made exphicit what was obvious from the advertising form-Zauderer engaged in the speech to make money.

Thus, cases addressing definitional issues yield sone evidence that the Court views profit and the profit motive as the cliaracteristic that distinguishes commercial speech from other types of speech. The Court, however, frequently has derried that this is the case, ${ }^{175}$ and if we are to conclude that it is the case we should want some stronger evidence. Such evidence may be found by comparing the commercial speech cases to another line of cases, those that address the first anendinent rights of charitable organizations and their solicitor agents.

\section{Charitable Organizations and the First Amendment}

Even before the Court cane to grips with the commercial speech problem in Valentine, it confronted similar probleins when considering laws regulating the efforts of rehgious and charitable organizations to proselytize on behalf of their causes and to collect funds to support such activity. Especially in inore recent years, these cases have taken on elements indistinguishable from those of the commercial speech cases. They therefore provide an excellent sounding board to determine precisely what defines commercial speecl.

Valentine's counterpart in the charitable organizations cases is Schneider v. State. ${ }^{176}$ In Schneider, the Court addressed a series of stat-

173. Zauderer, 471 U.S. at 641.

174. Id. at 646 .

175. See, e.g., Bates v. State Bar, 433 U.S. 350, 364 (1977) ("Even though the speaker's interest is largely economic, the Court has protected such speech in certain contexts."); Virginia Board, 425 U.S. at 761 ("[S]peech does not lose its First Amendment protection because inoney is spent to project it, as in a paid advertisement ... . Speech likewise is protected even though it is carried in a form that is 'sold' for profit, and even though it may involve a solicitation to purchase or otherwise pay or contribute inoney.") (citations omitted); Bigelow v. Virginia, 421 U.S. 809, 818 (1975) ("The existence of 'commercial activity, in itself, is no justification for narrowing the protection of expression secured by the First Amendment.' ") (quoting Ginzburg v. United States, 383 U.S. 463, 474 (1966)). Indeed, the distinction drawn in Fox implicitly rejects such a role. But see supra note 155 and aecompanying text (profit one of thrce elements inaking condoin pamphlet commercial speech); In re Primus, 436 U.S. 412, 438 n.32 (1978). ("Normally the purpose or inotive of the speaker is not central to First Amendment protection, but it does bear on the distinction betwecn conduct that is 'an associational aspect of "expression",' and other activity subject to plenary regulation by the government. . . . [A]ppellant's speech-as part of associational activity-was expression intended to advance 'behefs and ideas.' In [Ohralik] the lawyer was not engaged in associational activity for the advancement of behefs and ideas; his purpose was the advanceinent of his own commercial interests.") (quoting Einerson, Freedom of Association and Freedom of Expression, 74 YALE L.J. 1, 26 (1964), other citations omitted).

176. 308 U.S. 147 (1939). 
utes that prolibited liandbilling on public streets. ${ }^{177}$ Doctrinally, Schneider is important for two reasons. First, it introduced to the charitable organization eases a type of least-restrictive-means analysis ${ }^{178}$ that the Court held inapplicable to commercial speech in Fox.

Second, the Court expressly distinguished regulations on purely commercial solicitation from those on charitable solicitation, althougl the Court gave no reason for drawing this distinction. ${ }^{179}$ Indeed, at least one of the flyers at issue related to a pohitical meeting for which the sponsoring group charged an admission fee. ${ }^{180}$ Nevertheless, the Court did not inention this fact either in its discussion of first amendment principles or in its disclaimer regardimg commercial solicitation.

Schneider was followed by Cantwell v. Connecticut ${ }^{181}$ and Jamison v. Texas. ${ }^{182}$ Jamison involved a handbill distributed by a Jehovah's Witness that invited contributions for the group's books. ${ }^{183}$ The Court struck down regulations of the handbills and sought to distinguish thein from purely commercial handbills. ${ }^{184}$ Succinctly stating its conclusion, the Court held:

The states can prohibit the use of the streets for the distribution of purely commercial leaflets, even though such leaflets may have 'a civic appeal, or a moral platitude' appended. They may not prohibit the distri-

177. Id. at $154-58$.

178. The Court found the asserted state interests at issue could be accomplished by direct means, rather than indirectly through a prohibition upon handbilling. For example, the Court counseled the states that "[t]here are obvious methods of preventing hittering. Amongst these is the punishment of those who actually throw paper on the strects." Id. at 162. The Court rejected a fraud-based jnstification on similar reasoning:

Conceding that fraudulent appeals may be made in the name of charity and rehigion, we hold a municipality cannot, for this reason, require all who wish to disseminate ideas to present them first to police authorities for their consideration and approval. Frauds may be denounced as offenses and punished by law. Trespasses may similarly be forbidden.

Id. at 164 .

179. Id. at 165 ("We are not to be taken as holding that commercial soliciting and canvassing may not be subjected to such regulation as the ordinance requires.").

180. Id. at $155 \mathrm{n} .3$.

181. 310 U.S. 296 (1940). Cantwell is significant in part because of the offensive nature of the speech used by the defendant. Cantwell, a Jehovali's Witness, stopped passersby on a street in a heavily Catholic neighborhood and offered to play for them a phonograph record that:

[E]mbodie[d] a general attack on all organized religious systems as instruments of Satan and injurious to man; it then single[d] out the Roinan Catholic Church for strictnres couched in terms which naturally would offend not only persons of that persuasion, but all others who respect the honestly lield religious faith of their fellows.

Id. at 309. Despite the offensive nature of the speecl, the Court found "only an effort to persuade a willing listener to buy a book or to contribute money in the interest of what Cantwell ... conceived to be true religion." Id. at 310 .

182. 318 U.S. 413 (1943).

183. Id. at 414 .

184. Id. at 416-17. According to the Court, "[t]he mere presence of an advertisement of a religious work on a handbill of the sort distributed liere may not subject the distribution of the handbill to prohibition." 
bution of handbills in tlee pursuit of a clearly religious activity merely because the handbills mvite the purchase of books for the improved understanding of the religion or because the handbills seek in a lawful fashion to promote the raising of funds for religious purposes. ${ }^{185}$

The Court later recognized that "[s]ituations will arise where it will be difficult to determine whether a particular activity is rehigious or purely commercial,"186 and that "[t]his distinction at times is vital."187 Such recognition notwithstanding, the Court provided no guidance for Inaking this critical distinction, other than an implicit reference to its own intuition. Even inore importantly, the Court made absolutely no effort to explain why the distinction was so vital in terms of the values imphicated by the first amendinent.

These early cases largely involved efforts by the Court to protect the Jehovah's Witnesses froin discriminatory local laws. The primciples the Court set down, however, survived and reenerged to protect a inuch broader range of speech in Village of Schaumburg $v$. Citizens for a Better Environment. ${ }^{188}$ There, the Court addressed a local ordinance prohibiting door-to-door solicitation by organizations that used less than seventyfive percent of the funds they received for the charitable purpose described to potential donors. ${ }^{189}$

In striking down the statute, the Court inentioned briefly the earlier

185. Id. at 417 (quoting Valentine v. Chrestensen, 316 U.S. 52, 55 (1942)).

186. Murdock v. Pennsylvania, 319 U.S. 105, 110 (1943).

187. Id.

188. 444 U.S. 620 (1980).

189. Id. at 622-24. The Court also applied the least-restrictive-means analysis developed in Schneider to overcome the state's asserted interest in preventing fraud by claritable solicitors. As the Court noted,

[t]he Village urges that the 75-percent requirement is intimately related to substantial governmental interests 'in protecting the public froin fraud, crime and undue annoyance.' These interests are indeed substantial, but they are only periplierally promoted by the 75 . percent requirement and conld be sufficiently served by measures less destructive of First Amendment interests. Id. at 636.

The analysis is reminiscent of Posadas' discussion of the "fit" between a statute and its purported purposes. The fit required by Schaumburg appears to be substantially tighter than the fit Fox intimates will suffice for regulations of commercial speech. This analysis las been used in subsequent charitable solicitation cases. For example, in Seeretary of State of Maryland v. Joseph $\mathbf{H}$. Munson Co., 467 U.S. 947 (1984), the Court held that the statute "operates on a fundamentally mistaken premise that high solicitation costs are an accurate measure of fraud. That the statute in some of its applications actually prevents the misdirection of funds . . . is hittle more than fortuitous." Id. at 966-67 (footnotes omitted). The Court concluded that:

Where, as here, a state imposes a direct restriction on protected First Amendment activity, and where the defect in the statute is that the means chosen to accomplish the State's objeetives are too imprecise, so that in all its applications the statute creates an unnecessary risk of chilling free speech, the statute is properly subject to facial attack.

Id. at 967-68 (footnote ounitted); see also Riley v. National Fed'n of the Blind, Inc., 487 U.S. 781, 789 (1988) ("Our prior cases teach that the solicitation of cliaritable contributions is protected speech, and that using percentages to decide the legality of the fundraiser's fee is not narrowly tailored to the State's interest im preventing fraud."). 
charitable solicitation cases. Virginia Board, however, had been decided in the interim; thus the Court was forced to distinguish commercial speech, to which it had given only intermediate first amendment protection, from the speech of the charities at issue in Schaumburg, to which it wished to grant full first amendment protection. The Court found the commercial speech cases distinguishable "because charitable solicitation does more than inform private economic decisions and is not primarily concerned witl providing information about the characteristics of goods and services." 190 This rationale for the distinction has survived in subsequent cases. ${ }^{191}$

At first glance, this rationale appears to make sense witl respect to a certain kind of speech. Where speech provides only price information, sucl as in Virginia Board, or only information tliat a certam item is for sale or has been sold, such as in Linmark, we may feel comfortable saying that a charitable organization is likely to distribute more (and more important) information, or at least has done so in a given case.

We are, however, looking for a definition, presumptively applicable in all cases, not merely an explanation for the difference in the Court's treatment of certain cases. In this hight, the mformational theory of the definition of commercial speecl clearly fails. One need only look to Bolger, Zauderer, and Fox to see that some commercial speech provides miportant and socially useful information. Indeed, by examining the effect that a change in speaker would have on the speech at issue in Bolger we can see that the definition of commercial speech in fact turns upon the profit motive of the speaker rather than the speech itself.

Simply put, under Schaumburg and its progeny an eight-page pamphlet discussing venereal disease and the use of condoms and distributed (as indicated by one line at the bottom of the eighth page) by the American Red Cross or Planned Parentlood or some other nonprofit health-oriented group would not be commercial speech. By replacing that hine with the name of a drug store and a specific brand name condom, however, the entire pamphlet may be transformed into commercial speech. ${ }^{192}$

Similarly, an advertisement regarding the potential adverse health

190. Schaumburg, 444 U.S. at 632.

191. See Riley, 487 U.S. at 788 ("charitable solicitations 'involve a variety of speech interests ... that are within the protection of the First Amendment,' and therefore have not been dealt with as 'purely commercial speech' ") (citing Schaumburg, 444 U.S. at 632).

192. Planned Parenthood v. Clark County School District, 887 F.2d 935 (9th Cir. 1989), provides a striking example of this distinction in action. There, Planned Parenthood sued a school district for banning its advertisements from school newspapers. Reinarkably, at least from a doctrinal point of view, "[t]he school district conced[ed] that Planned Parenthood's advertisements are protected speech under the first amendment. This case does not require us to decide the extent, if any, Planned Parenthood's advertisements constitute commercial speech . ..." 887 F.2d at 939. 
effects of the Dalkon Shield distributed by a nonprofit public health group would not be commercial speech under Schaumburg. Indeed, this result would not change even if the advertisement contained the names of several attorneys who had handled such cases and who were in good standing with the local bar association. ${ }^{193}$ The result might not change even if contingent fees were listed for each attorney. But what if only one attorney's name were listed?

These examples deinonstrate the level of uncertainty engendered by the continuum Justice Scalia identified imphicitly in Fox. ${ }^{194}$ More importantly, there appears to be no difference, at least not one grounded in the first amendment, between the commercial speech in Bolger and Zauderer and the fully protected speech conteinplated by Schaumburg. In fact, the only identifiable difference between "charitable speecli" and "commercial speech" are the speakers and their motives, not the content of the speech.

\section{Commercial Speech as a Negative Number}

A final characteristic of commercial speecl makes inescapable the conclusion drawn froin the preceding Seetion. The Court treats commercial speech differently than any otler form of speech by burdening it with the ability to deprive fully protected speecl of the protection it otherwise would receive. Justice White, as noted above, made this very clear in Zauderer. In this sense, commercial speech is parasitic or, to choose a matheinatical metaplior, a negative number tliat, when added to the positive value of fully protected speecl, lessens that value.

At first glance this seems reasonable. After all, a speaker making an otlierwise protected speecli tliat ended with "fighting words"195 would not be immune from punishment by virtue of the protected portion of the speech. ${ }^{196}$ The same result would obtain for speech ending with obscen-

While this conclusion undoubtedly was correct given the current state of the cases, it can be justified only by reference to the profit continuum.

This distinction also may be seen in Justice Black's dissent in Breard. Justice Black argued there that the prohibition against door-to-door solicitation of magazine subscriptions was unconstitutional because "[t]le constitutional sanctuary for the press must necessarily include the liberty to publisl and circulate." Breard v. Alexandria, 341 U.S. 622, 650 (1951) (Black, J., dissenting). Nevertheless, he also believed that, as apphied to a merchant "selling pots," the prohibition would be constitutional. Although not made exphicit, it is at least arguable that this distinction turned upon what Jnstice Black perceived to be the different quantum of socially valuable speecl at issue in each case.

193. The speecl described liere would in fact be nothing unore than a more general form of the speech at issue in Primus. See supra note 175. Indeed, although the basis for decision in Primus was slightly different from the charitable organization cases, the Court there expressly relied upon the profit inotive to distinguish Primus from Ohralik. See id. In this sense, Primus and Ohralik together form a microcosm of the charitable and commercial speecli cases.

194. See supra note 157.

195. See Chaplinsky v. New Hampshire, 315 U.S. 568, 570-73 (1942).

196. Indeed, the speaker in Chaplinsky, a Jehovah's Witness, had engaged im protected conduct 
ity. ${ }^{197}$ Such speech, however, is fundamentally different from the Court's treatment of mixed commercial and social or political speech. In both the fighting words and obscemity cases, the objectionable speech functions as a negative in fact-the speech works an affirmative harm, either by inciting a violent response or by violating community standards of decency. In such circumstances, it seems reasonable not to allow the protected. speech to protect otherwise pumishable speech. ${ }^{198}$

By contrast, the current commercial speech doctrime allows entirely truthful commercial speech to deprive otherwise fully protected speech of first amendment protection. Indeed, that is precisely what happened in Zauderer, Bolger, and Fox. In such cases, the cominercial speech actually adds information to the advertisement, such as where to buy the relevant product or service and at what price. The only remaining factor that could serve as the negative is the profit motive introduced in cominercial speech cases. Thus, the presence of a speaker's intent to profit by virtue of her speech activity appears to be the factor that, when found, signals the presence of commercial speech. This conclusion leads in turn to the consideration of two related issues: the logical and doctrinal irrelevance of profit and profit motives, and the consequently overly broad definition of commercial speech.

The first issue hardly seems to be an issue at all. At least since Burstyn and New York Times, the Court contmuously has asserted that whether speech is made for profit is irrelevant to the level of protection appropriate for the speech. ${ }^{199}$ This assertion makes sense given the wide variety of profit-motivated speech to which the Court has extended full first amendment protection, such as speech seeking legislative action that would violate antitrust laws if made by private parties, ${ }^{200}$ or, indeed, the sale of the New York Times and the Washington Post.

These assertions may appear irrelevant here; after all the definition of commercial speech and the level of protection it should receive are conceptually distinct issues. Nevertheless, when the Court uses the profit

until he addressed a police officer as "a God damned racketeer" and "a damned Fascist." Id. at 56970.

197. Assuming the validity of obscenity laws, the result is clear. See Miller v. California, 413 U.S. 15, 27-28 (1973).

198. It also is interesting to note the tighter "fit" required between the ends and nieans of regulations of fighting words and obscenity when conipared to the fit required of regulations of commercial speech. In the first two cases the fit nuust be more precise because regulations of fighting words and obscenity are true content-based regulations-in both cases the speech itself is regulated. The Court tolerates a looser fit in commercial speech cases because the true object of the regulation in such cases frequently is not the speech itself but sonie external factor, such as fraud.

199. See supra note 26.

200. See Eastern R.R. Presidents Conference v. Noerr Motor Freight, Inc., 365 U.S. 127, 139 40 (1961); see also First Nat'1 Bank of Boston v. Bellotti, 435 U.S. 765 (1978); Schauer, Architecture, supra note 8 , at 1183 n.11. 
motive to categorize speech and to deny it full first amendment protection, the Court's statements that the profit motive of speech is irrelevant ring somewhat hollow.

The Court, however, is absolutely right in saying that a profit motive is irrelevant to analyzing speech. Whatever we may wish to say about classifymg speech by its content, or by its secondary effects, there is simply no way to classify speech based upon the speaker's motives, at least not where the content of the speech is itself unobjectionable. ${ }^{201}$ First, a motive-based theory of protecting commercial speech is fundamentally at odds with the Court's treatment of other categories of speech within the first amendment. Even if Chaplinsky had been aware of the doctrine he inspired, and strongly desired to utter fighting words, he should not be punished if he im fact failed to do so, regardless of his intent. $^{202}$

Similarly, even if a person desired to distribute obscene materials, she should not be punished for handing out copies of Ulysses. ${ }^{203}$ And certainly a person making a speech regarding a ballot initiative would not lose full first amendinent protection because her speech was motivated by the economic benefit the speaker expected to realize if the imitiative passed. Moreover, the pursuit of profits is merely one way in which people seek gratification, as is the pursuit of political change. All speech seeks gratification in this broad sense, but the Court, quite rightly, is not about to uphold all speech regulations on that ground.

Such a broad gratification analysis reveals yet agam that the Court's emphasis upon profit motivation in commercial speech cases actually refiects its unarticulated suspicion of profit-motivated speech as soinehow more dangerous or less worthy of protection than other forms of speech that seek gratification. To this extent the Court's definitional analysis,

201. See Hustler Magazine v. Falwell, 485 U.S. 46, 53 (1988) ("while such a bad motive may be deemed controlling for purposes of tort hability in other areas of the law, we think the First Amendment prohibits such a result in the area of public debate about public figures"); Post, The Constitutional Concept of Public Discourse: Outrageous Opinion, Democratic Deliberation and Hustler Magazine v. Falwell, 103 HARv. L. REv. 601, 647-49 (1990) (noting the relationship between intent requireinents and civility rules). Motive does, of course, play some role in certain aspects of first amendment jurisprudence. A defendant's hatred of a person she allegedly hbeled presumably would be at least somewhat probative of actual malice. This role, however, cannot serve to classify speech because it says nothing about the speech itself, ouly about what it may be intended to do.

202. I am lere assuming an objective standard for judging when speeeh consists of fighting words. See Chaplinsky, 315 U.S. at 573 ("The test is what men of common intelligence would understand would be words likely to cause an average addressee to fight." ") (quoting State v. Chaplinsky, 91 N.H. 310, 320, 18 A.2d 754, 762 (1941) (lower court decision)). Thus, even if Chaplinsky had wanted to address the police officer as a fascist or racketeer, his speech would not constitute fighting words if all he managed to say was "officer, I strongly disagree with your suppression of my speech."

203. United States v. One Book Called “Ulysses," 5 F. Supp. 182 (S.D.N.Y. 1933). 
and consequently the fit required of a statute regulating commercial speech, turns upon the Court's predilections rather than upon first amendment analysis.

Additionally, at least in the mixed speech cases, the Court's consideration of the profit motive ineans that it ends up classifying speakers (and then only by their motives) instead of speech. ${ }^{204}$ This at least partly explaims why the current definition of commercial speech is so confusing in its apphication. Take, for example, the Central Hudson construction of the definition-commercial speech is speech that proposes a commercial transaction. ${ }^{205}$ The definition claims to and should turn on the content of the speech. Indeed, by its terms, the definition purports to ask what the speech does, not what the speaker hopes it will do.

The Court's application of tle definition, liowever, does not turn solely, or even primarily, upon the content of the speech. Some speech with obvious cultural importance, such as that im Bolger and Zauderer, fits under the definition, but would not if made by a different speaker. To the extent the definition of commercial speech deviates from its purported goal of categorizing speech according to content, its apphication seems random and hapliazard.

Consequently, the Court's decisions have provided little guidance to speakers seeking to determine whetlier their speecli will be classified as commercial, unless they take the time to parse out of the cases the Court's profit einphasis and establish cliarities. In this sense the Court's current definitional focus fails the inost fundamental requireinent of the definition of a first amendment category: informing speakers of what will liappen to tlieir speech. To tlie extent the Court's focus causes speakers soine uncertainty, the Court's definitional approacli may chill soine cominercial speech and a great deal of speecli that should not be classified as commercial at all.

Even more importantly, the profit motive is meaningless in terms of the values implicated by the first amendment. Whatever we decide those values are, ${ }^{206}$ it seeins obvious that profit-motivated speech is as capable

204. For example, imagine a cigarette advertisement soliciting the sale of a certain brand of cigarette because it lias the lowest tar or nicotine. Made by the producer of the cigarette involved, the advertisement is cominercial speech. But what if the same advertisement is made by a conscience-stricken competitor who hopes that the people she has addicted to sinoking at least smoke the "safest" brand?

While the result is not entirely clear, the eases give us at least a strong inturition that the advertisement would receive different protection if distribnted by the competitor. It almost certainly would receive closer attention from the Court. In this way, again, commercial speecli is different from any other definitional category in the first amendment. Speecls falling under the fighting words doctrine does so regardless of who speaks the words and for what motive. The same is true for obscenity.

205. See supra note 27.

206. The variety of options is addressed in Part III, infra. 
of advancing their realization as is speech motivated by altruism, political gain, or any other motive. Consider, for exainple, a speaker who campaigns for a presidential candidate because she expects to benefit economically if her candidate is elected. Though motivated by profit, her speech is as important to the democratic process as it would be if it were motivated by pure ideology.

Finally, emphasizing the speaker's motivation ignores the interests of prospective histeners. Listener imterests, which form the foundation of the commercial speech doctrine, ${ }^{207}$ depend largely upon the speech itself. While knowing the motive of a speaker might help a histener evaluate the speech, it certainly is not necessary for the speech to have value to the histener.

Therefore, the current definition of commercial speech rests in large part upon the profit motive, a factor entirely irrelevant to the values implicated by the first ainendment, the first ainendment doctrines crafted by the Court, or almost anything else. The balance of this Section exainmes an empirical example of the results of this doctrinal confusion, and offers a tentative proposal for a new way of addressing the definitional problem.

\section{A Case Study in Definitional Confusion: The Northrop Corporate Image Advertisements}

A perfect example of how the Court's definitional ambignity confuses first amendment analysis arose from television advertisements broadcast by Northrop Corporation on the eve of a major criminal trial. Facing an mdictment alleging fraudulent testing practices, Northrop aired several commercials in the Los Angeles market that featured former test pilot Chuck Yeager and depicted the corporation as honest and hard working. ${ }^{208}$ The government sought a prior restraint prohibiting Northrop from airing the commercials in the Los Angeles market, ${ }^{209}$ arguing the advertisements would bias potential jurors im favor of Northrop. ${ }^{210}$

Northrop argned that the commercials were necessary to enhance its public image, which was a key to its ability to attract new employees and to its relationship with its suppliers. ${ }^{211}$ Northrop also argued that a

207. See supra note 43 and accompanying text.

208. See Judge Says Northrop Ads Could Impair Fair Trial, L.A. Times, February 16, 1990, at D1, col. 4; Northrop's Image Ads, Televised on Trial's Eve, Spark U.S. Objection, but Appeals Court Lifts Ban, Wall St. J., February 20, 1990, § 1, at 22, col. 1 [hereinafter Northrop Image Ads].

209. Id.; see also Memorandum of Law Regarding the Court's Options With Respect To Extrajudicial Comments, United States v. Northrop Corp. (No. CR 89-303 (A)-PAR) at 11-12 (proposed restraining order) [hereinafter Goverument Meinorandum].

210. Government Memorandum, supra note 209, at 3-4.

211. See Northrop Corporation's Meinorandum In Opposition to The Government's Motion 
prior restraint was unwarranted because several less restrictive alternatives, such as voir dire, were available to ensure that the actual jurors would not be biased. ${ }^{212}$

The district court issued the prior restraint, ${ }^{213}$ which the Ninth Circuit stayed. ${ }^{214}$ Although the case later settled, ${ }^{215}$ the district court's definitional analysis reveals how intractable lower courts have found the definition of commercial speech. The court began by defining commercial speech as "expression related solely to the economic interests of the speaker and its audience," the first of the two Central Hudson definitions. ${ }^{216}$ Not surprisingly given this broad definition, the court then found that "even though the advertisennents are not designed to induce consumers to purchase a specific product or service, they fall within the definition of commercial speech."217

This result, however, is clearly wrong. Not only did Central Hudson couch its discussion in terms of "speech proposing a commercial transaction," 218 but no subsequent case has used that definition. ${ }^{219}$ Moreover, even though the definition in Fox disguises the Court's rehance upon the profit inotive, the opinion inakes clear that Central Hudson's reference to "the economic interests of the speaker" does not define commercial speech. ${ }^{220}$ Indeed, it is hard to conceive of speech pertaining to the credibility of a inajor defense contractor as anything but core speech, especially when the speech in no way proposed a commercial transaction.

In addition to delnonstrating the ambiguity of the Court's definition, the district court's opmion exemplifies the close relationship between the definitional question and the substantive protection given the speeeh at issue in any given case. Einploying the excessively broad Central Hudson language to define the speech as commercial, the court then used that definition to justify the prior restramt. ${ }^{221}$ Thus, rather than using the

For Restraining Order Regarding Extra-Judicial Statements of Parties and Their Agents, United States v. Northrop Corp. (No. CR $89-903$ (A)-PAR) at 8 [hereinafter Northrop Memorandum].

212. Northrop Meniorandum, supra note 211, at 15-16. This argument was supported by reference to Nebraska Press Association v. Stuart, 427 U.S. 539 (1976), which established guidelines for determining the permissibility of prior restraints.

213. Memorandum of Decision and Order, United States v. Northrop Corp. (No. CR 89-903 (A)-PAR) at 15 .

214. See Northrop Image Ads, supra note 208.

215. Northrop Fined \$17 Million in Fraud Case, L.A. Times February 28, 1990, § 1, at 1, col. 6.

216. Memorandum of Decision and Order, supra note 213, at 6.

217. Id.

218. Central Hudson Gas \& Elec. Corp. v. Pub. Serv. Comm'n, 447 U.S. 557, 562 (1980).

219. See supra notes 148-50.

220. See supra text accompanying notes $159-61$.

221. Memorandum of Decision and Order, supra note 213, at 6. As the court put it: "Though no commercial speech case thus far has addressed fair trial issues, the Court has approved what are in effect prior restraints of what it perceives as less valuable commercial speech, applying a lower 
stringent less-restrictive-means methodology required in most prior restraint cases, ${ }^{222}$ the court applied the four-part Central Hudson analysis, under which the result was almost a foregone conclusion. ${ }^{223}$

Consequently, the court restrained speech of clear public importance. The court erroneously defined the speecl as commercial and, therefore, analyzed the restraint under an erroneously deferential standard. Altlough tlie district court's confusion on the definitional question is perfectly understandable given the confused state of the doctrine, its implications are nevertheless intolerable. Thus, at a minimum, we need a new, clear definition of commercial speech-a definition keyed to the first ainendment value structure. The next Section proposes doctrinal modification toward tliat end.

\section{An Alternative Definitional Approach}

The immediate result of the Court's implicit reliance upon the profit motive to define commercial speech is that the Court inevitably sweeps far too much speech under the definition. To say Virginia Board is a commercial speech case because the price advertisennents there offered qualitatively and quantitatively less information than speech we wish to protect fully under the first ainendment is one thing. To say Zauderer is also a commercial speech case is quite another, and to say Bolger or San Francisco Arts \& Athletics are commercial speech cases is questionable at best.

The speech at issue in these cases varies in the anount and type of information conveyed, the topics addressed, and the manner im which the speech was presented. The cases can be classified together only by reference to the profit motive of their speakers, and even that link is dubious with respect to San Francisco Arts \& Athletics. ${ }^{224}$ As noted above, however, using a profit motive as a common denommator yields a class of speakers, not speecli. Witli respect to content, any classification that purports to include those four cases is no classification at all.

All this does, however, yield an idea about how to repair the defini-

level of constitutional scrutiny." Id. For this proposition, the court cited Posadas and Central Hudson, neither of which specifically addressed the prior restraint issue. Indeed, Posadas' greaterpower lesser-power rationale seems particularly curious (and vulnerable) when invoked as to the speech of a defense contractor.

222. See Nebraska Press Ass'n v. Stuart, 427 U.S. 539, 562-70 (1976).

223. See Memorandum of Decision and Order, supra note 213, at 7.

224. San Francisco Arts \& Athletics, Inc., v. United States Olympic Comm., 483 U.S. 522 (1987), did not turn as obviously upon the profit motive as did Zauderer and Bolger. Nevertheless, the Court's references to trademark principles indicated the profit motive played at least some role in the decision. Id. at 532-35. The other elements included the USOC's obvious distaste for the use of the word "Olympic" in conjunction with homosexual activity, as evidenced by the USOC's acquiescence in the use of its word by police and charitable organizations. Id. at 570 (Brennan, J., dissenting). 
tion somewhat, without major structural changes in the architecture of the doctrine or the first amendment. First, commercial speech should be treated as a positive number. That is to say, the mixed speech cases are not commercial speech cases at all, under any definition, and the Court should not try to fit them into the doctrine. ${ }^{225}$

This construction admittedly might lead advertisers to seek full first amendment protection by linking the goods or services they advertise to social or pohtical issues. Despite the Court's apparent hostility to it, however, one might well ask what is wrong with such linkage. If the commercial portion of the speech is independently regulable, such as for falsity, then the speech as a whole may be regulated on that basis. ${ }^{226}$

If there is no such independent basis for regulation, however, all the speech in the mixed speech cases is valuable for first amendment purposes ${ }^{227}$ and should be given full first amendment protection. At least until the Court is able to articulate a reason, grounded in the first amendment, why one line of solicitation is enough to move otherwise cultural or political speech imto the commercial speech category, it should not give the line such power. ${ }^{228}$

Therefore, in each case the Court should look at the content of the speech and the function of the actual words or images used. It should then apply a modified version of the original Virginia Board definition of commercial speech-speech that does no more than propose a commercial transaction, without regard for motivation, profit or otherwise. The modification must come in the Court's use of the word "commercial" in the definition. As noted above, unless the definition refers to all transactions, the use of "commercial" in the definition results in a tautology. ${ }^{229}$ Thus, a better definition would be "speech that does no more than propase the sale of a specific, named good or service." This effectively would limit the category to the speech envisioned in Virginia Board: an offer to sell $(X)$ good or service at $(Y)$ price. ${ }^{230}$

There is simply no justification for deeming other forms of speech

225. This definition assumes that the commercial speech at issue is not independently regulable, as for falsity.

226. This result would bring the commercial speech cases into line with the fighting words and obscenity cases. Issues of regulation generally, and of false advertising in particular, are addressed in Part V, infra.

227. The nature of that value is developed more fully in Part III, infra.

228. See infra Part III. While this position inight appear extreme, it really does no more than give effect, in light of subsequent cases, to the holding in Vinginia Board that commercial speakers do not have to justify themselves by bootstrap references to social or political topics in order to receive first amendment protection. Virginia State Bd. of Pharmacy v. Virginia Citizens Consumer Council, Inc., 425 U.S. 748, 761-65 (1976).

229. See supra note 145.

230. Virginia Board, 425 U.S. at 761 . In fact, this definition is something of an amalgam of the Virginia Board definition and the definition proposed in Note, New Constitutional Doctrine, supra 
commercial. Such efforts inevitably rely, implicitly if not exphicitly, upon the profit notive, which the Court itself deems irrelevant. ${ }^{231}$ And such efforts inevitably result in speech that deserves full first amendment protection being deprived of such protection by being defined as commercial speeeh.

Present commercial speech doctrine encoinpasses far inore speech than even the arguments supporting the special, intermediate level of first amendment protection given commercial speech can justify. This state of affairs, by itself, is an "architectural" imphication of the current doctrine. To borrow the inetaphor, to the extent the subset of commercial speech is too large for its doctrinal foundations, it weakens the entire doctrinal structure. This situation calls for remedial construction work. The scope of the category inust be narrowed to reflect the definition set forth above.

The architectural implications of the current doctrine go beyond the shaky foundation supporting the treatment of commercial speech. As presently constituted, the doctrine poses a threat to other first amendment doctrine, and to forms of speech we presently do not view as commercial. These implications may be grouped into two categories: (1) the use of commercial speeeh as a talisman to resolve certain difficult speech problems; and (2) the doctrinal inconsistencies created by the current commercial speech doctrine.

\section{B. The Talismanic Value of Commercial Speech}

The Court occasionally has used commercial speech as a sort of talisman to resolve sticky first amendment issues in hard cases that involve some combination of profit and speech-most notably Ohralik and San Francisco Arts \& Athletics. ${ }^{232}$ When used in this way, commercial speech provides the Court with a doctrinal pool of indefinite breadth froin which the Court may extract an intermediate level of protection, a rationale for not applying the overbreadth doctrine, or soine similar characteristic of the commercial speech doctrine, as necessary to resolve (or sidestep) the speech issues involved.

note 36, at 236. As to the latter, however, this definition is informed more by subsequent experience and closer attention to the underlying values of the first amendment. See supra note 147.

This definition rejects consideration of the profit motive, which was an element of the definition in the Note. The profit motive is unnecessary because commentators on commercial topics, who were the Note's concern, are protected by requiring that speech propose a transaction. When we define out of the category speech that does more than propose a commercial transaction, wc automatically except commentators from the definition. The provision of this definition requiring reference to a specific product is incorporated from the Note.

231. See supra note 175 and accompanying text.

232. See supra text accompanying notes 66-72 (Ohralik) and text accompanying notes 115-26 (San Francisco Arts \& Athletics). 
San Francisco Arts \& Athletics is perhaps the best example of this problem. First, the case liad very little, if anything, to do with commercial speech. The Court deemed the use of the phrase "Gay Olympic Games" on shirts and bumper stickers to be the commercial speech at issue. ${ }^{233}$ The shirts and bumper stickers at issue in San Francisco Arts \& Athletics, lowever, were no more proposals to consummate a commercial transaction than were the books offered for sale in the New York Times analogy. ${ }^{234}$ They were the subject of the transaction.

Put another way, the sponsors of the games were not selling blank shirts and bumper stickers with the phrase "Gay Olympic Games" attaclied to make the purchase more attractive any inore thian a bookstore sells blank books with soine text attached to mcrease the likelihood of sales. In both cases, the commodity being sold includes the message conveyed by the language affixed to the books or to the shirts, which are themselves properly considered as a mechanism for displaying the message. If commercial speecli were involved, even under the Court's normal definition, it would have taken the form of speech proposing the purcliase of tlie shirts.

Similarly, in Ohralik the Court sought to allow a state to punish what was, as noted above, a course of conduct incidentally imvolving speech. ${ }^{235}$ The Court, lowever, failed properly to distinguish Ohralik's conduct from the invitations to deal at issue in Bates, perhaps because Ohralik's conduct was not, as one might expect, the consummation of a transaction. It was instead the infliction of duress and, perhaps, fraud. ${ }^{236}$ The basis of the decision was the attorney's conduct, which was so egregious that the Court beheved the state needed the freedom to regulate his conduct, regardless of the value of the speech involved.

233. San Francisco Arts \& Athletics, Inc., v. United States Olympic Comm., 483 U.S. 522, 53940 (1987). The Court essentially bootstrapped these items into the commercial speech doctrine by redefining commercial speech in terms of the relevant statute. The Court held that "[t]o the extent that [the statute] applies to uses 'for the purpose of trade [or] to induce the sale of any goods or services,' its application is to commercial speech." Id. at 535 (quoting 36 U.S.C. \& 380(a)).

The statute's first clause clearly could not define the speech as commercial, even under the Court's definition. Thus, the speech became commercial because it induced the sale of the relevant itenus, a definition used by the Court only in San Francisco Arts \& Athletics. It should be apparent that the "inducing the purchase" test is impossibly broad, encompassing speech that would escape even a profit-notive definition. For example, under this definition, speech on the U.S. trade deficit could be considered commercial speech for inducing the purchase of donestic products, especially if the speech included references to the names of specific donestic products.

234. See supra text accounpanying note 26.

235. Ohralik v. Ohio State Bar Ass'n, 436 U.S. 447, 464-65 (1978); see also Zauderer v. Office of Disciplinary Counsel, 471 U.S. 626, 641 (1985) ("Our decision in Ohralik was largely grounded on the substantial differences between face-to-face solicitation and the advertising we had held pernissible in Bates. In-person solicitation by a lawyer ... [is] a practice rife with possibilities for overreaching, invasion of privacy, the exercise of undue influence, and outright fraud."); Shapero v. Kentucky Bar Ass'n, 486 U.S. 466, $474-75$ (1988).

236. See infra text accompanying notes 411-18. 
That decision undoubtedly was correct. The Court, however, simply did not need to devalue the attorney's speech to reach this result-the attorney's course of conduct was independently regulable. ${ }^{237}$ In fact, viewed apart froin the conduct, the speech used in Ohralik was not very different from speech the Court has found protected in subsequent attorney advertising cases, ${ }^{238}$ and those cases have viewed Ohralik primarily as allowing restrictions on forms of solicitation likely to impose duress upon the histener. ${ }^{239}$

Thus, the present commercial speech doctrine poses a danger to the rest of the first amendinent because there is always a possibility that the doctrine will be applied to deny first amendinent protection to speech that is not commercial speech at all. This would, perhaps, be acceptable if the commercial speech doctrine were reasonably clear, and if the speech to which it could be apphed were reasonably well defined, in terms that made sense under the first amendment. The existing commercial speech cases, however, will support almost any apphication of the doctrine: all the Court needs to do is find a link between the speech and profit. This practice perpetuates itself, and grows even broader through apphication, because each peculiar apphication of the doctrine becoines precedent for future, even more peculiar apphications.

In turn, as the apphications become more peculiar, the commercial speech doctrine is increasingly burdened with the doctrinal baggage created by the Court to deal with the peculiar applications. Thus, to deal with the mixed speech-conduct in Ohralik, the Court created the leveling rationale, ${ }^{240}$ which it could then apply in subsequent cases, without regard for the unique circuinstances of the rationale's creation and without appreciating that the rationale came into being to dispose of a case that should not have been decided on commercial speech grounds in the first place. ${ }^{241}$ In fact, this process is precisely how the Court applied the

237. I am here using "conduct" to refer generally to the circumstances of the solicitation, as described by Justice Marshall. See supra notes 69-72.

238. The speech in Ohralik included information on the terms of representation offered by the lawyer and on the legal rights of the prospective clients. 436 U.S. at $450-51$. Sinilar information was conveyed by the mailings in Shapero, 486 U.S. at 469 , and the advertisements in In re RMJ, 455 U.S. 191, 196-97 (1982) and Zauderer, 471 U.S. at 630-31, 637 n.7.

239. See supra note 235. This fact ironically has inade attorney advertising perhaps the inost well-protected form of comnercial speech, despite the trepidation with which thc Court originally extended protection to such speecl. The simple reason is that the Court has been coinparing speech regulations to the permissible prohibition in Ohralik, which applied uniquely to the mix of speech and conduct in that case. Although the Court permitted a complete ban in Ohralik, it lias been easy for subsequent attorneys to distinguish their pure speech activities. This factor does not, of course, explaim the results in all the attorney advertising eases. The extreine nature of the regulations in those cases, generally complete prohibitions on speech, certainly played a substantial role as well.

240. See infra Section IV(D) for a critique of this rationale.

241. Indeed, if the rationale is valid at all, it should be limited to the mixed speech and conduct context of Ohralik. 
commercial speech exception to the overbreadth doctrine in San Francisco Arts \& Athletics. ${ }^{242}$

\section{Commercial Speech and Doctrinal Inconsistency}

The problems posed by the treatment of the overbreadth doctrine in commercial speech cases go farther than the use of commercial speech as a talisman. The treatinent of the overbreadth doctrine is simply one example of how the commercial speech doctrine can perinutate other first amendment doctrines, thereby undermining their architectural strength. This Section reviews and criticizes the Court's reasons for exceptimg commercial speech from the overbreadth doctrine. It then examines the Court's use of the overbreadth doctrine in areas outside commercial speech where the reasons also apphed. This analysis demonstrates that the Court's reasons, in Bates ${ }^{243}$ and subsequent cases, for not applying the overbreadth doctrine to commercial speech apply to speech generically, not just to commercial speech. Nevertheless, the Court has failed both to apply the exception uniformly, in conformity with its rationale, and to distinguish speech to which the rationale applies but to which the exception does not.

To reiterate briefly, the Court held the overbreadth doctrine inapphcable to commercial speech for two reasons. First, the Court believed that a commercial speaker "can determine inore readily than others whether his speech is truthful and [therefore] protected." 244 In certain circumstances, this reasoning seeins correct. The pharmacist who advertises drugs at a given price should know better than anyone else whether she will sell thein at that price.

It is, however, easy to oversell this rationale. As Professor Farber has noted, the speech inay concern a good or service about which too bittle is known to label the speech false. ${ }^{245}$ Moreover, an enorinous amount of what we commonly think of as commercial speech is neither

242. See supra note 224. Indeed, San Francisco Arts \& Athletics' holding that the overbreadth doctrine would not be applied is a paradigm of this process. The holding cited Ohralik for the proposition that the overbreadth doctrine was inapplicable to commercial speech. San Francisco Arts \& Athletics, 483 U.S. at 536 n.15. Ohralik in turn relied upon Bates, Ohralik, 436 U.S. at 462 n.20, which simply declared that the overbreadth doctrine was inapplicable to commercial speech. Bates v. State Bar, 433 U.S. 350, 380-81 (1977). Bates, in turn, inerely incorporated the famous dicta of Virginia Board's footnote 24. Virginia Board, 425 U.S. at 771-72 n.24.

At one level this process simply reflects a failure carefully to analyze the support and relevance offered by past authority. The process is, however, somewhat unique in the commercial speech doctrine because the numerous doctrinal weak spots make every case a potential landmine.

243. Bates, 433 U.S. at 381.

244. Id.

245. Farber, supra note 144, at 385 ("inost deceptive speech consists not of false statements but of half-truths and misleading yet hiterally correct assertions. Such speech inay not fall within the class of 'false statements of fact' which [the Supreine Court] found entirely lacking in first amendment value"). 
true nor false; it is not truth-evaluative at all. ${ }^{246}$ Easy examples are advertisements that link products to certain attributes such as masculinity. While the Marlboro Man is certainly making a statement, how do we know whether it is true?

The Court's first reason is really a supporting component of the second-the assumed greater durability of commercial speech. Yet this rationale is even more troubling. The Court asserted that "[s]ince advertising is linked to commercial well-being, it seems unlikely that such speech is particularly susceptible to being crushed by overbroad regulation." 247 This reasoning, however, is not grounded in any type of first amendment analysis at all. Rather, it is an empirical prediction about the behavior of potential speakers when faced with overbroad regulations.

The Court assumes that potential commercial speakers will be sufficiently motivated by profit to run the risk of being pumished by an overbroad regulation. The Court's analysis, however, is far too cursory. As Professor Farber points out, it is impossible to determine the chilling power of regulations of certain types of specch in the abstract; unless one knows what the prospective penalty is, one cannot predict that a speaker will risk its imposition. ${ }^{248}$ Additionally, if the Court is to make a prediction about the behavior of speakers, it should at least be more careful than it was in apparently assuming, as Professor Farber put it, that "greed is more effective than idealism in motivating people to risk government sanctions. One would at least hope that the contrary would be true."249

The empirical nature of its rationale notwithstandimg, the Court's only citation in Bates was to Virginia Board, which simply asserted the conclusion. ${ }^{250}$ The Court offered no statistical or even anecdotal support for the conclusion, and actual practice has called its validity into

246. See infra text accompanying notes 319-21.

247. Bates, 433 U.S. at 381 (citing Virginia Board, 425 U.S. at 771 n.24). The Court's reliance upon the profit motive to justify its refusal to apply the overbreadth doctrine strengthens the conclusion that the Court has not discarded the profit motive in its commercial speech analysis. This use of the profit motive also simplifies the question of what speech should be subject to the exception. Since the Court rehies upon the profit motive to define commercial speecl, any speech it decides is commercial will, by definition and assumption, be robust enough to resist overbroad regulations.

248. Farber, supra note 144, at 386.

249. Id. Indeed, the argument from profit logically contains its own limitations. Specifically, the argument assumes that, to some extent, commercial speakers are rational economic actors. Thus, in keeping with this assumption, such speakers will not fight to vindicate their first amendment rights once the cost of engaging in the prohibited speech exceeds the economic benefits that they expect to realize froin making that speech. That point will necessarily differ from case to case, a variable the Court ignores.

250. See supra text accompanying notes 49-53. 
question. $^{251}$

All this demonstrates, however, only that another aspect of the commercial speech doctrine lacks analytical support. The more important point here is that even if the Court's reasons for excepting commercial speech from the overbreadth doctrine were correct, the Court has not apphied that exception in other cases where the same reasons should warrant such application. The Court does not apply this exception neutrally, ${ }^{252}$ but rather only in cases where the Court wishes to uphold a regulation of speech.

The noncommercial speech cases-such as those involving charitable organizations-in which the Court's reasons for excepting commercial speech from the overbreadth doctrine are equally apphicable, but where the exception is not invoked, demonstrate that the Court has apphied the commercial speech exception to the overbreadth doctrine in a nonneutral fashion. For example, the Court refuses to apply the overbreadth doctrine to commercial speech cases because of the greater verifiability and profit-based resistance to chill that inheres in commercial speech. The same resistance to chill, however, logically exists with respect to the charitable organization cases. As Justice White admitted in Schaumburg:

Soliciting financial support is undoubtedly subject to reasonable regulation but the latter must be undertaken witl due regard for the reality that solicitation is characteristically intertwined witl informative and perliaps persuasive speech seeking support for particular causes or for particular views on economic, political or social issues, and for the reality that without solicitation the flow of such information and advocacy would likely cease. ${ }^{253}$

At first glance, such speech actually appears to be the opposite of

251. See supra text accompanying notes 241-47. Additionally, in both Virginia Board and Fox the commercial speakers dropped out of the lawsuits after losing in the district court, despite the overbreadth of both statutes. See Virginia Board, 425 U.S. at 753; Board of Trustees v. Fox, 109 S. Ct. 3028, 3030 (1989). That both speakers preferred to abandon constitutional challenges and forego their speech rather than seek to vindicate their rights seems to call into question the validity of the Court's assumption.

252. I am here using the term "neutrally" to refer to the method of adjudication commonly traced to Professor Wechsler. See Wechsler, Toward Neutral Principles of Constitutional Law, 73 HaRv. L. Rev. 1 (1959). Professor Schauer uses the alternative but largely synonymous term "articulate consistency." As he describes it, the term means "that when we jnstify a decision by reference to a principle (or a reason, rule, standard, jnstification, or theory) we must be willing to apply the principle, as articulated in the first decision, to all cases coming within the verbal description of that principle." Schauer, Must Speech Be Speciall, 78 Nw. U.L. REv. 1284, 1296 (1983) [hereunafter Schauer, Special Speech].

In this portion of the discussion I assume the Court's reasons are valid, despite the preceding criticisin. The point here is not that the reasons are bad, only that the Court does not apply them consistently.

253. Village of Schaumburg v. Citizens for a Better Env't, 444 U.S. 620, 632 (1980) (emphasis added). 
commercial speech. Using the Court's assumption, commercial speech is resistant to chill because commercial speakers want to make money and therefore will engage in speech regardless of overbroad regulations. Seemingly conversely, the speakers Justice White is talking about want to engage in speech, and therefore inust ask for money.

Upon closer examination, however, we can see that the commercial speech exception to the overbreadth doctrine should not be unique to profit-motivated speech; the exception is based upon the strength of the relevant motive, rather than the content of the speech. Thus, the logic of the exception apphies to all speech supported by a motive sufficient to resist overbroad regulation. Profit, at least according to the Court, is one such motive, and the exception should apply to all speech supported by a motive of equal or greater strength. Thus, the Court can neutrally apply the commercial speech exception to the overbreadth doctrine only if it assumes that profit is a stronger motivator than, for example, ideology or altruism. Simply stating the assumption, it appears to have an intuitive, pragmatic appeal-along the same lines as the Court's "cominon sense distinction" between commercial and other speech. ${ }^{254}$

Notwithstanding such intiritive appeal, however, this assumption cannot be maintained. Initially, as a descriptive matter, we are back to guessing about the reality of speakers and speech in everyday hife. Nevertheless, two different empirical factors indicate that speakers motivated by ideology are in fact more resistant to the sanction of overbroad regulation than are speakers motivated by profit.

First, even a quick perusal of only the most famous free speech cases shows that persons motivated by ideology are willing to risk a wide array of sanctions, from prosecution, fines, and imprisoument ${ }^{255}$ to social opprobrium. ${ }^{256}$ These sanctions are at least as severe, and in most cases

254. See supra note 65. The phrase, not surprisingly, originated in Virginia Board's footnote 24. Virginia Board, 425 U.S. at 771 n.24.

255. See, e.g., Texas v. Johnson, 109 S. Ct. 2533, 2537 (1989) (sentence of one year in prison and \$2,000 fine for flag burning); Brandenburg v. Ohio, 395 U.S. 444, 445 (1969) (sentence of one to ten years in prison and $\$ 1,000$ fine for speech at $\mathrm{Ku}$ Klux Klan rally); Yates v. United States, 354 U.S. 296, 302-03 (1957) (sentence of five years in prison and $\$ 10,000$ fine for organizing communist party and advocating communism); Dennis v. United States, 341 U.S. 494 (1951) (federal criminal conviction for organizing communist party and advocating communisin); Whitney v. California, 274 U.S. 357, 363-65 (1926) (state conviction for similar activity); Gitlow v. New York, 268 U.S. 652, 654 (1925) (sentence of imprisonment for advocating anarchy); Abrams v. United States, 250 U.S. 616, 617 (1919) (convietion for publishing "disloyal, scurrilous and abusive language about the form of Government of the Umited States"); Debs v. United States, 249 U.S. 211, 212 (1919) (sentence of ten years in prison for giving speech on the growth and desirability of socialisin); Schenck v. United States, 249 U.S. 47, 49 (1919) (federal conviction for speech obstructing the draft).

256. See, e.g., Collin v. Smith, 578 F.2d 1197, 1199 (7th Cir. 1978), stay denied, 436 U.S. 953, cert. denied, 439 U.S. 916 (1978) (Nazi marchers in village with large Jewish population); Cantwell v. Connecticut, 310 U.S. 296, 301-03 (1940) (Jehovall's witness proselytizing in a neighborhood composed of over $90 \%$ Roman Catholics). The sanctions in these cases were, of course, unofficial. 
much more severe, than sanctions commonly imposed upon commercial speech such as, for example, fining a corporation for issuing a false advertisement and enjoining further distribution of the advertisement. ${ }^{257}$

Second, a comparison between the commercial speech cases and the charitable organization cases demonstrates that charitable speakers appear at least as likely as commercial speakers to seek vindication of their first amendment rights. The coinunercial speakers in Virginia Board ${ }^{258}$ and $F o x^{259}$ preferred to abandon their speech efforts rather than press litigation, while the opposite was true of the speakers in Schaumburg ${ }^{260}$ and Riley. ${ }^{261}$ This is an admittedly crude measure of the relative strengths of the motives involved. Nevertheless, to the extent that charitable speakers are as willing or more willing to challenge speech regulations as are commercial speakers, the inotivation for charitable speech seems to be at least as strong as the motivation for commercial speech. ${ }^{262}$

As noted above, the commercial speech exception to the overbreadth doctrine rests upon the implicit assumption that speech motivated by profit is relatively more durable than speech supported by a nonprofit motivation. That assumption, like the Court's underlying assumption regarding the strength of the profit inotive, reflects a combination of empirical observation and prediction. If these empirical observations and predictions are wrong, the assumptions resting upon them are unjustified and cannot support the commercial speech exception. Therefore, if nonprofit motives for engaging in speech are as strong or stronger than profit motives, the structure supporting the Court's implicit assumption collapses.

All this leaves the Court with two options. First, it can maintain its refusal to apply the overbreadth doctrine in commercial speech cases,

Nevertheless, in both cases the sanctions were foreseeable, if not inevitable, and therefore reflect the strength of the respective speakers' motivation.

257. The archetypal regulation I envision here is roughly of the type at issue in National Commission on Egg Nutrition v. F.T.C., 570 F.2d 157, 159 (7th Cir. 1977), cert. denied, 439 U.S. 821 (1978). The F.T.C used the statute, 15 U.S.C. $\S \S 45$ and 52, to restrain an egg industry group from publishing advertisements discussing the relationship, or lack thereof, between eggs and heart disease. While the group was not fined, I assume for purposes of the discussion in the text that a fine could be included as a sanction in the archetypal regulation.

258. See supra note 251.

259. Board of Trustees v. Fox, 109 S. Ct. 3028, 3030-31 (1989).

260. Schaumburg, 444 U.S. at 624-26.

261. Riley v. National Fed'n of the Blind, Inc., 487 U.S. 781, 787 (1988). Riley does not support the point as strongly as Schaumburg because the plaintiff charitable organizations in Riley were part of a coalition that included professional fundraisers and donors. Id. It is possible the charities would not have pursued litigation absent support from other coalition nembers.

262. The one exception to this generalization appears to be the attorney advertising cases encompassed by the commercial speech doctrine. For whatever reasou, attorneys seein inore likely to challenge adverse rulings than other commercial speakers. 
perpetuating an inaccurate assumption in a way that violates the neutrality principle. Alternatively, the Court can apply neutrally the rule gleaned froin its durability assumption. The result of this latter approach would be to discard the overbreadth doctrine altogether, because the overbreadth doctrine then would apply only to speech that inattered little to the speakers, and perhaps even less to prospective listeners. Significantly, neutral application of the Court's reasoning would eliminate the overbreadth doctrine from the area that it was designed to protect ${ }^{263}$ ideologically motivated speech. ${ }^{264}$

Finally, the Court could acknowledge that the assuinptions underlying the commercial speecl exception to the overbreadth doctrine are unwarranted, and apply the overbreadth doctrine in commercial speech cases. So long as it does not apply the commercial speecl doctrine to overbreadth cases, the Court weakens the structure of its first amendment jurisprudence. The Court's failure to apply its rationale neutrally hides but does not eliminate the doctrine's weakness. And although the unacceptable resnlts neutral application of the Court's reasoning would dictate seem farfetched so long as the Court steadfastly adheres to nonneutral application, it certainly would be preferable to rectify the doctrinal flaws by applying the doctrine neutrally.

The overbreadth doctrine is not the only example of the Court violating neutral application of its reasoning in the commercial speech area. We could as easily focus on violations of the principle of viewpoint neutrality, ${ }^{265}$ or any of a number of other principles. The overbreadth example, however, proves the main point: as presently constructed the commercial speech doctrine threatens the integrity of some highly valued first ainendment principles because the Court has treated those principles differently in commercial speeclı cases, without good reasons for doing so. Such treatinent weakens both the commercial speech doctrine and the other doctrines that suffer unprincipled treatinent due to commercial speech.

All this depicts a fairly dismal picture of current commercial speech doctrine. There are, of course, at least two remedies to the situation. The Court could follow Justice Brennan and extend substantially complete first ainendment protection to commercial speech. Alternatively, it could follow Chief Justice Rehnquist and overturn Virginia Board, its apparent current path. Only the foriner option is consistent with the theory and purposes of the first amendment, as Part III deinonstrates.

263. See cases cited supra note 242.

264. See cases cited supra note 255.

265. See infra text accompanying notes 252-54. 


\section{III \\ THEORETICAL CONSIDERATIONS AND COMMERCIAL SPEECH}

The recent academic einphasis upon developing theoretical rationales to extend or deny first amendment protection to speech has yielded a plethora of potential reasons for protecting speech. These reasons include fostering the discovery of truth, fostering social stability through toleration, deterring abuses of authority, fostering individual autonomy and self-realization, and facilitating liberal democracy. ${ }^{266}$

Some of these justifications have been used to develop coherent rationales for protecting ${ }^{267}$ or not protecting ${ }^{268}$ commercial speech. Unfortunately, the Court has neither participated in this development nor explicitly engaged in the dialogue that fuels it. Rather, the Court simply has declared commercial speech is not at the "core" of the first amendment and, therefore, receives an "intermediate" level of first amendment protection. ${ }^{269}$

This Part makes two arguments. First, it argues that even the most mundane commercial speech enhances an individual's rational decisionmaking and thus contributes to rationality, a value implicated by the first amendment. ${ }^{270}$ Second, this Part argues that commercial speech plays a significant role in developing the recipients' self-image and perception of the world. In this capacity, commercial speech directly fosters self-realization, also a value protected by the first amendment.

Before embarking on this Section, two issues must be made clear. The first concerns my use of rationality and self-realization. For purposes of this Section, I am using rationality to imdicate the capacity for what may be called, for lack of a better phrase, linear thought. When speech either trains our minds or gives us the information to say "because A therefore B," it implicates the rationality value. ${ }^{271}$

266. These rationales are collected and briefly described in Greenawalt, Free Speech Justifications, 89 Colum. L. Rev. 119 (1989). Professor Greenawalt divides these justifications into what he deems "consequentialist" and "non-consequentialist" categories, which correspond roughly to deontological and ontological reasons for protecting the freedom of speech.

267. Perhaps the most prominent advocate of this view is Professor Redish. See Redish, The First Amendment in the Marketplace: Commercial Speech and the Values of Free Expression, 39 GeO. WASH. L. Rev. 429, 431 (1971) [hereinafter Redish, The Fint Amendment in the Marketplace]; Redish, The Value of Free Speech, 130 U. PA. L. Rev. 591, 630, 635 (1982); see also Farber, supra note 144.

268. Professor Baker is the principal advocate of this view. See Baker, Commercial Speech: $A$ Problem in the Theory of Freedom, 62 IowA L. REv. 1, 1 (1976).

269. See Ohralik v. Ohio State Bar Ass'n, 436 U.S. 447, 456 (1978).

270. Redish, The First Amendment in the Marketplace. supra note 267. This Part does not argue, as does Professor Redish, that self-realization is the single unifying value that underlies the first amendment. See Redish, The Value of Free Speech, supra note 267, at 593.

271. This definition is refined somewhat below, but it will do for now. 
Self-realization is somewhat more difficult. For Professor Redish the term refers either to the development of the individual in the sense of achieving her potential, or to the individual's abihity to control her own destiny. ${ }^{272}$ Having placed the development of the individual's rational capacities withm the ambit of the rationality value, I use the selfrealization value to refer to the imdividual's extrarational (as opposed to irrational) capacities. Thus, the value is implicated by speech that appeals to our emotions or helps us shape our perception of ourselves and the world around us. ${ }^{273}$

Second, not all commercial speech implicates both arguments made in this Section, nor should it be expected to. Commercial speech is not monohithic, as the Court often treats it, but covers an enormous variety of speech, and different types of commercial speech implicate different first amendment values.

\section{A. Commercial Speech, Rationality, and Self-Realization: An Introduction}

Long before commercial speech gamed protection in Virginia Board, Professor Redish argued that such protection should be extended because commercial speech proinotes the developinent of rational decisionmaking:

When the individual is presented with rational grounds for preferring one product or brand over another, he is encouraged to consider the competing information, weigh it mentally in hight of the goals of personal satisfaction he has set for himself, counter-balance his conclusions with possible price differentials, and in so domg exercise his abilities to reason and think; this aids him towards the intangible goal of rational selffulfillment. ${ }^{274}$

The argument froin rationality simpliciter tells us nothing. Given the enormous variety of ways that unprotected speech may stimulate an

272. Redish, The Value of Free Speech, supra note 267, at 593.

273. I here have in mind roughly what Professor Post refers to as rules of demeanor: "conduct by which a 'Person expresses to those in his immediate presence that he is a person of certain desirable or undesirable qualities." " Post, The Social Foundations of Privacy: Community and Self in the Common Law Tort, 77 Calif. L. Rev. 957, 962 (1989) [hereinafter Post, Social Foundations] (quoting E. GOFFMAN, The Nature of Deference and Demeanor, in INTERACTION RITUAL: Essays ON FACE-TO-FACE BEHAVIOR 47, 47 (1967)).

274. Redish, The Fint Amendment in the Marketplace, supra note 267, at 443-44; Professor Baker rejects this view, arguing that corporate and other profit-motivated speech is inimical to selfrealization. Baker, Realizing Self-Realization: Corporate Political Expenditures and Redish's The Value of Frec Speech, 130 U. PA. L. REv. 646 (1982); Redish, Self-Realization, Democracy, and Freedom of Expression: A Reply to Professor Baker, 130 U. PA. L. REv. 673 (1982). Professor Shiffrin also thoroughly has critiqued Professor Baker's position. See, Shiffrin, supra note 147, at 1237-40.

Redish's argument portrays rationality as a subset or subvalue of the larger self-realization value. Thus, although Professor Baker responds only to the self-realization argunnent, he also rejects Professor Redish's rationality-based arguunent. 
individual's abilities to reason and think, a much more refined analysis is required. ${ }^{275}$ As with many areas of the first amendment, inatters of degree ultimately are determinative. Nevertheless, focusing upon the connection between commercial speech and rationality gives us a sohd analytical foundation from which to proceed.

I assume for present purposes that the first amendment seeks to foster rationality and self-realization, and that commercial speech is capable of enhancing the realization of these values. Working from these assumptions, I argue courts (and even Professor Redish) have given insufficient attention to the degree to which commercial speech fosters these values. ${ }^{276}$

\section{Judicial Considerations of Rationality}

The Court has recognized two ways in which commercial speech arguably implicates the rationality interests of recipients of such speech. First, the Court has acknowledged that commercial speech is of substantial concern to persons considering whether or where to purchase a product or service. Indeed, the Court recognized "the particular consumer's interest in the free flow of commercial infornation . . . may be as keen, if not keener by far, than his interest in the day's most urgent political debate."277 In this respect, commercial speech provides infornation that

275. For an example of this problem, see infra note 335 .

276. These assumptions are discussed in somewhat greater detail in Section IV(A) and Part V, infra. Nevertheless, an initial level of justification is useful here. The proposition that the first amendment secks to foster rationality makes sense under either a consequentialist or nonconsequentialist conception of the first amendment, to borrow Professor Greenawalt's terminology. See Greenawalt, supra note 266. Any consequentialist theory, such as democratic selfrule, necessarily assumes individuals will be able rationally to utilize the information they receive to realize the ultimate value, such as democracy. As Professor Redish notes, "[i]f men possessed no power of reason or judgment, there would be no justification for encouraging them to aid in society's political decision-1naking process." Redish, The First Amendment in the Marketplace, supra note 267 , at 439.

My purpose here is only to establish that rationality is an iniportant value and is protected by the first amendment. Under Professor Greenawalt's structure, it also is a nonconsequentialist jnstification. As Jnstice Brandeis put it, "[t]hose who won our independence beheved that the final end of the state was to make men free to develop their faculties . . ." Whitney v. Califorma, 274 U.S. 357, 375 (1927) (Brandeis, J., concurring). For present purposes, I believe it is sufficient to assert that the nonconsequentialist reasons for believing that rationality is a value protected by the first amendinent apply with equal force to the self-realization value.

The proposition that commercial speech is capable of fostering rationality and self-realization is part of the argument of this Part. I assume here only that self-realization and rationality legitimately implicate listener interests, and that the source of speech should not determine the protection that it is afforded. Both these arguments are at the heart of the debate contained in the articles cited in note 274, supra. (In essence, I am assuming that Professor Baker's thesis is incorrect, without contributing my own arguments to the debate.)

277. Virginia State Bd. of Pharmacy v. Virginia Citizens Consumer Council, Inc., 425 U.S. 748, 763 (1976). 
allows consumers to make rational choices about where to buy a product and what price they are willing to pay.

Second, the Court has recognized that commercial speech provides information that consumers may use in deciding whether and to what extent to regulate an industry or practice. ${ }^{278}$ Thus, commercial speech provides information that helps the individual to address noneconomic questions in a rational inanner. At the level of the rationality value, commercial speech in this sense is indistinguishable froin "core" speech $^{279}$ because the decision whether or to what extent to regulate an industry or practice almost invariably will be "pohtical."

This is not to say that there is a "political" rationality that is different from "commercial" rationality. To the contrary, the rationality value exists at the level of the capacity to reason, and is miphicated by speech that enhances that capacity or apphes it to different subject inatter. Thus, only the source of the information is "commercial"; the rational thought process that is einployed is generic. The thought process is simply brought to bear by speech on different topics-one political the other commercial. ${ }^{280}$

A simple example will deinonstrate the point. If a store advertised the sale of legal but worrisome products, such as automated assanlt rifles, the advertisement itself could, and probably would, be denominated commercial speech. If the outraged citizenry then undertook to ban the sale of autonated assault rifles, their actions quite appropriately would be considered pohtical, as would the speech they used. ${ }^{281}$ While it does not transform the original advertisement from commercial speech to political speech, the commercial speech serves as the catalyst for the political speech by brimging the rational faculties of the individual to bear on a subject, thus implicatimg the rationality value. This contribution is important, and should be kept in mind when designing a regime for the protection of commercial speech.

This argument is distinct from its apparently similar relative, which asserts that commercial speech must be protected because it is difficult to draw a line between commercial and political speech. That form of argu-

278. Id. at 765 .

279. The concept of the "core" meaning of the first amendment is explored by Professor Schauer. See Schauer, Architecture, supra note 8 , at 1185 . This concept is analyzed more fully in note 355 , infra.

280. This approach to analyzing speech is very different from the approach the Court appears to take, but it may not be so different from the Court's underlying methodology.

281. Professor Farber provides further examples. See Farber, supra note 144, at 382 ("[I]nformation about the quality and price of some products may relate to important political issues. For example, a behef that American cars are overpriced influences views on foreign car import restrictions, on inflationary price increases of domestic cars, and on the effects of olgopoly."). Professor Shiffrim also offers extensive discussion on this point. See Shiffrin, supra note 147 , at $1226-30$. 
ment attempts to classify speech by reference to topic, rather than to the relevant underlying values. Moreover, as Professor Schauer has pointed out, arguments based upon the difficulty of drawing lines "are based on a fallacious view of the nature of language, one that presupposes that a distinction that cannot be drawn sharply should not be drawn at all."282

Rather, this argument holds that at the level of the rationality value it is irrelevant whether we can draw a clear line between commercial and pohtical speech because speech on both commercial and pohitical topics fosters that value. At a less abstract level there still should be no problem, because even speech we can agree should be denominated "commercial" is not solely for that reason devoid of political effect. ${ }^{283}$

\section{Professor Redish's View}

As noted above, in his early work Professor Redish argued that commercial speech should receive first amendment protection because such speech fostered imdividual rationality. At the time, the contribution of commercial speech to rationality was enough for Redish, who perceived individual rationality to be a key to self-realization-a value protected by the first amendment. ${ }^{284}$ Pursuant to this version of the theory, Professor Redish originally beheved "informational" advertising deserved complete first amendment protection, while merely persuasive advertismg could be more heavily regulated. ${ }^{285}$ Professor Redish has since rejected this distinction, ${ }^{286}$ but Professor Lowenstein now advocates a version of it. ${ }^{287}$

282. Schauer, Architecture, supra note 8, at 1189 (citing Schauer, Slippery Slopes, 99 HARV. L. REV. 361 (1985)).

283. This argument is more closely related to, but still distinct from, the notion that speech that appears commercial, without even a hint of political conteut, may itself be political depending upon the circumstances into which the speech is introduced. See infra Section II.

284. Redish, The First Amendment in the Marketplace, supra note 267, at 438-39. This position was a coinponent of a larger argument holding that "individual self-government" is a necessary prerequisite to political self-government. Id. Professor Redish since has expanded his theory to hold that "self-realization" is the unifying value of the first amendment. Redish, The Value of Free Speech, supra note 267, at 595-96. As noted earlier, Redish defines "self-realization" to include both individual development and individual self-governance coinponents. Id. This latter coinponeut appears to incorporate inuch of the rationality emphasis of Redish's earlier work.

None of the arguments in this Comment assumes or relies upon Professor Redisli's larger view of self-realization as the single value that underlies the first amendinent. Indeed, iny treatment of rationality and self-realization as logically distinct values is contrary to his view. His insight into the ability of commercial speech to promote rationality is valuable, and has been adopted (at least informally) by the Court. See Virginia Board, 425 U.S. at 748. I address his version of the argunent here because it clarifies the strouger version of the argument, which I present in Section III(B). But arguimg that self-realizatiou lies alone at the root of the first amendment poses several analytical difficulties. See, e.g., Schauer, Special Speech, supra note 252.

285. Redisl, The First Amendment in the Marketplace, supra note 267, at 445-47.

286. Redish, The Value of Free Speech, supra note 267, at 630 n.135.

287. Lowenstein, "Too Much Puff": Persuasion, Paternalism, and Commercial Speech, 56 U. CiN. L. REV. 1205, 1208, 1231-36 (1988). 
Redish's original argument differs from the version adopted by the Court because it emphasizes the contribution of commercial speech to the individual's broader capacity to reason rather than to make a discrete economic decision. Nevertheless, largely because the original argument accepted the distinction between informational and persuasive advertising, it failed to take into account the full mipact of advertising in fostering rationality and self-realization. ${ }^{288}$

\section{B. Taking Commercial Speech Seriously}

As noted above, the Court does not think commercial speech is as imiportant as other kinds of speech. The Court addressed the possible significance of commercial speech inost thoroughly in Virginia Board and has rarely examined the issue in any depth since then. This Section argues that because the Court has failed to consider the broad effects of commercial speech it has given insufficient weight to the social interests imphicated by such speech. Specifically, this Section inaintains that even commercial speech that at first appears devoid of any informational content still inay contribute substantially to rationality and self-realization.

Simiply put, even advertisements that convey no information about a product's price or sales location still communicate ideas and information cognizable under the first ainendment. Consuniers are free to reject the ideas as irrational or just plain silly; they are free simply to ignore the information presented. Nevertheless, they also are free to accept the ideas and/or information presented, possibly through the purchase of a product or service. Any legitimiate atteinpt to regulate such advertiseinents inust deal with the reality of the ideas and information communicated.

To see how commercial speech works in this regard, it is helpful to divide the category into two forms: "informational" commercial speech, which conveys only product or service price and location information, and "persuasive" commercial speech, which seeks to inake the product or service more attractive to potential consumers. These categories are rough, and the division does not inean that speech in one category cannot contain elements of speech in the other. Nevertheless, both the general doctrimes the Court has erected around the first amendment and the doctrimes the Court has erected specifically for commercial speech act in different ways on the two types of commercial speech isolated here. Commercial speech is not a monohthic category; this Section attempts in part to demonstrate how siguificant those distinctions are, and why the commercial speech doctrime must be revised to take them into account.

288. Professor Redish has not addressed this issue extensively since he revised his theory, but it seems safe to assume he would have at least some sympathy with the arguments presented below. 


\section{1. "Informational" Commercial Speech}

Perhaps the archetypal form of commercial speech is an advertisement that contains information indicating where and at what price a product or service may be obtained. Such advertisements were at issue, with varying informational content, in Virginia Board, ${ }^{289}$ Bates, ${ }^{290}$ Linmark $^{291}$ (although the commercial speech there contained somewhat less information) and Bigelow ${ }^{292}$ (although the commercial speech there contained shightly more information). As noted above, ${ }^{293}$ such commercial speech implicates primarily the rationality value, by providing consumers with information they need to distinguish among competing products and services, and to make decisions about the regulation of certain products or services.

The rationality value of even such bare-boned speech, however, far exceeds the mere facilitation of a wise purchase. Indeed, the Court sometimes treats informational commercial speech as noncommercial speech. ${ }^{294}$ For example, in Bigelow the Court treated an advertisement describing the availability of abortions in New York as essentially noncommercial speech. As the Court saw it, "[the advertisement] contained factual material of clear 'public interest." "295 The portions to which the Court referred were simply lines on the advertisement indicating that abortions were legal in New York, and that women did not have to be New York residents to obtain them. ${ }^{296}$

Information on the legality and availability of a product or service is, however, at least in the abstract, standard informational commercial speech. As then-Justice Relinquist noted in dissent, "the advertisement appears to me ... to be a classic commercial proposition directed toward the exchange of services rather than the exchange of ideas."297 This is not to say, as did Justice Relinquist, that the informational commercial

289. The regulation at issue in Virginia Board prohibited price advertising. The hypothetical speech envisioned by the Court was "I will sell you the X prescription drug at the $Y$ price." 425 U.S. at 761.

290. Bates v. State Bar, 433 U.S. 350, 385 (1977) (reprinting the advertisenent).

291. Linmark Assocs. v. Township of Willingboro, 431 U.S. 85, 86 (1977) ("for sale" and "sold" signs).

292. Bigelow v. Virginia, 421 U.S. 809, 812 (1975) (quoting the text of the advertisenent).

293. See supra text accoinpanying notes 277-82.

294. Such treatinent is different froin informational commercial speech that serves a role in prompting, for example, political speech. Here, outside forces transform into political speech what the Court otherwise would deem purely infornational commercial speech.

295. Bigelow, 421 U.S. at 822.

296. Id. Indeed, the Court apparently behieved the advertisennent could have been treated as noncommercial speech even without this information: "The mere existence of the Women's Pavilion in New York City, with the possibility of its being typical of other organizations there, and the availability of the services offered, were not unnewsworthy. Also, the activity advertised pertained to constitutional interests." Id.

297. Id. at 831 (Rehnquist, J., dissenting). 
speech at issue in Bigelow did not inerit the first amendment protection it received. Rather, Bigelow makes clear that no speech, includimg informational commercial speech, should be judged in a vacuum. The difference between advertising the availability of abortions at a time when states and the Court are grappling with the legality of abortion and at a time when they are not is the same difference that would result in differing protection for the cry of fire in a crowded and an empty theatre. ${ }^{298}$

Bigelow raises another curious line of commercial speech analysis that we must distinguish in order properly to evaluate the value of commercial speech. Both Chief Justice Relinquist ${ }^{299}$ and at least one commentator ${ }^{300}$ have used Bigelow to fashion a rule that commercial speech regarding an activity that is itself constitutionally protected is either somehow more valuable ${ }^{301}$ than commercial speech regarding other activities, or is not commercial speech at all. ${ }^{302}$ The theory behind this rule is apparently that "[t]he additional value of such advertising does not depend on the presence of any ideas or information of public interest in the advertisement . . . but derives from the constitutionally protected subject being promoted." ${ }^{303}$ This theory, however, appears to have vir-

298. Bigelow is by no means an exceptional case; such advertisements are as common and diverse as the social and pohtical atmosphere of the day. To take an example well publicized when this Comment was written, one need only imagine an advertisement for a book such as Salman Rushdie's The Satanic Verses. A bookstore advertisement should be considered commercial speech under present standards (which is not to say it would be), even if the advertisement discussed thc book's hiterary and cnltural significance. This is not to say, of course, that the advertisements should receive some lesser quantum of first amendment protection.

299. See Posadas de Puerto Rico Assocs. v. Tourism Co., 478 U.S. 328, 345-46 (1986).

300. See Note, New Constitutional Doctrine, supra note 36, at 235-36.

301. Posadas, 478 U.S. at 345-46.

302. Note, New Constitutional Doctrine, supra note 36, at 235-36.

303. Id. The argument in Posadas was somewhat different. There, Justice Rchnquist used the constitutional status of the abortion services at issue in Bigelow to distinguish that case on the ground that the state did not have the greater power to ban abortions, and therefore did not have the lesser power to regulate speech regarding abortion services. If Justice Rehnquist's argument is limited to that form, then the criticism in the balance of this Part is inapplicable. In that event the distinction would turn upon the validity of the greater power/lesser power rationale, which is analyzed in Section IV(B), infra. Even apart from Posadas, however, the arguments below are relevant to the distimction Justice Black attempted to draw in Breard. See supra note 22.

Justice Rehnquist's argument in Posadas is somewhat surprising because the Court in Bigelow emphasized both the public interest in the information contained in the advertisement and the constitutional status of abortion services. Indeed, the Court saw the two interests as separate, noting "[t] he mere existence of the Women's Pavilion in New York City ... [was] not unnewsworthy. Also, the activity advertised pertained to constitutional interests." Bigelow, 421 U.S. at 822 (einphasis added).

This interest, of course, was almost surely generated in large part by thc debate over the constitutionality of restrictions on abortion. Nevertheless, an advertisenent certainly could generate similar public interest even without the constitutional element, such as an advertisement for a new drug to treat AIDS. Admittedly, this is not the strongest evidence that the Court in Bigelow would liave ruled the way it did if the speecl gave out important information on a nonconstitutional snbject. If the Court would not have ruled the same way, the arguments in this Part would suggest 
tually no doctrinal support.

First, if the theory accurately describes the current doctrine, the Court obviously has not applied it neutrally, holding that Zauderer could be sanctioned for advertising as a criminal defense attorney ${ }^{304}$ without a single reference to the right to counsel, ${ }^{305}$ and holding that no attorney could solicit in dormitories in Fox. ${ }^{306}$ Additionally, to the extent counmercial speech requires the Court to apply only an intermediate level of protection to speech, the definitional result in Bolger is contrary to the theory. ${ }^{307}$ Moreover, there is no need to look to the subject matter of the speech; as speech such as the advertisement in Bigelow can serve first amendinent values regardless of the subject matter of the speech. Such speech therefore deserves first amendinent protection on its own merits.

Additionally, the mechamism by which the constitutional value of underlying activity takes on value for first amendment purposes is mysterious. Initially, we are entitled to inquire as to the exchange rate for such a transaction. This may seem facetious, but it is not. Of late the constitutional protection afforded abortion by the right to privacy changes with every terin. Does that mean the level of first amendment protection afforded to abortion advertiseinents changes also? One would hope not, but it is hard to sec how to avoid that result.

Finally, a converse analysis demonstrates the theory's curious nature. If an abortion advertisement contained fighting words a court presumably would not disregard that fact because the subject of the specch was abortion, nor would it (hopefully) deny protection to an artistic depiction of an illegal act because the act was illegal. The first amendment value of speech must be considered apart from the subject of the speech.

Informational commercial speech that conveys inore than simply the location and price of a good implicates the first amendment values discussed above to an even greater degree. Thus, for example, an automobile advertisement discussing the relative merits of passive restramt devices and nnaking a logical claim that one device (used on the advertised car) is superior to another may provide an introduction to, as well as an opimion on, an ongoing debate over automobile safety standards. ${ }^{308}$

Thus, informational commercial speech deserves protection because

Bigelow was wrongly decided. Nevertheless, under the overall argument of the Comment Bigelow was clearly decided correctly, regardless of the constitutional status of abortion.

304. Zauderer v. Office of Disciplinary Counsel, 471 U.S. 626, 655 (1985).

305. U.S. CoNST. amend. VI.

306. See supra note 129.

307. Since contraceptives are protected by the same right of privacy that protects the right to an abortion, the definitional result in Bolger undermined the constitutionally protected status of the condoms advertised.

308. See Selling Autos By Selling Safety, N.Y. Times, January 26, 1990, at D1, col.3. 
people want to hear it and, when heard, it helps people to run their hives. To put it in more palatable academic terms, informational commercial speech implicates substantial histener interests, even though the content of the speech may appear inundane relative to the content of other types of speech. ${ }^{309}$ Additionally, circumstances may heighten the listener's interest to such a point that the speech is not treated as commercial at all, but receives protection usually reserved for more traditional forms of speech.

\section{Persuasive Commercial Speech}

The second branch of commercial speech covers speech that atteinpts to link a product or service to an idea or image that the speaker believes will be attractive to consumers. Speech in this branch may appeal to the rationality value, but more likely will appeal to the selfrealization value by helping people to form views of the world and themselves. Thus, when an individual purchases a product in response to an advertisement that associates the product with a desirable trait or characteristic with which the individual desires to associate herself, she has responded to persuasive commercial speech.

The best place to begin this argument is witl the sole judicial opinion that takes persuasive commercial speech seriously. In Banzhaf $v$. F.C.C. ${ }^{310}$ the court gave judicial recoginition to the broad communicative impact of some very inundane advertisements. Banzhaf involved a law professor's effort to have the F.C.C.'s "fairness doctrine"311 applied to television cigarette advertisements.

Banzhaf contended cigarette advertisements "seek to create the impression and present the point of view that sinoking is socially acceptable and desirable, manly, and a necessary part of a ricli, full life." 312 This portrayal, Banzhaf argued, presented only one side of a "controversial issue of public importance." 313 The F.C.C. agreed, and held "a station which presents such advertisements has the duty of informing its audi-

309. This is not to say that informational commercial speech does not promote speaker interests. Speakers may engage in informational commercial speech in order to promote aggregate economic efficiency, or for motives other than individual economic gain. Assuming that such other motives would imiplicate speaker interests cognizable under the first amendment, the inquiry actually requires a motive analysis.

310. 405 F.2d 1082, 1101-02 (D.C. Cir. 1968), cert. denied, Tobacco Inst., Inc. v. F.C.C., 396 U.S. 842 (1969).

311. The "fairness doctrine" required F.C.C. licensees " "to operate in the public interest and to afford reasonable -opportunity for the discussion of conflicting views on issues of public imiportance." Larus \& Bro. Co. v. F.C.C., 447 F.2d 876, 878 n.3 (4th Cir. 1971) (quoting 47 U.S.C. $\S 315(a))$. The constitutionality of the doctrine was upheld in Red Lion Broadcasting v. F.C.C., 395 U.S. 367 (1969).

312. Banzhaf, 405 F.2d at 1086.

313. Id. 
ence of the other side of this controversial issue." 314 The court upheld the F.C.C.'s determination.

Banzhaf became unimportant when the ban on cigarette advertising on television was upheld. ${ }^{315}$ Nevertheless, the case is important as the high-water inark of true content analysis of commercial speech. The Banzhaf court took seriously the messages sent to the public when it recognized that cigarette commercials sought to convey an idea-that cigarettes are "manly" and "part of a rich full life."316 Regardless of whether these ideas were or are significant social arguments, Banzhaf was correct in acknowledging that the advertisements offered those ideas to consumers. ${ }^{317}$ Dissenting im a later case, Judge J. Skelly Wright rehed upon Banzhaf to make the point succinctly:

It would be difficult to argue that there are many who mourn for the Marlboro Man or miss the ungrammatical Winston jimgles. Most television viewers no doubt agree that cigarette advertising represents the carping hucksterisin of Madison Avenue at its very worst. Moreover, overwhelming scientific evidence makes plain that the Salem girl was in fact a seductive inerchant of death-that the real "Marlboro Country" is the graveyard. But the First Amendment does not protect only speech that is healthy or harmless. The Court of Appeals in this circuit has approved the view that "cigarette advertising implicitly states a position on a inatter of public controversy." For me, that finding is enough to place such advertising within the core protection of the First Amendment. ${ }^{318}$

While neither Banzhaf nor later cases revealed the process by which such speech was analyzed or upon which advertisements they rehed, a couple of examples will clarify the process of parsing out the communicative content in even commonplace advertisements.

Imagine a magazine advertisement depicting a young man, dressed im expensive clothes, leaning on a sports car while appraising a scantilyclad woman approaching him. Even if the only written matter on the

314. Id.

315. See Capital Broadcasting Co. v. Mitchell, 333 F. Supp. 582 (D.D.C. 1971), aff'd, 405 U.S. 1000 (1972).

316. Banzhaf, 405 F.2d at 1086.

317. This interpretation of Banzhaf is at odds with the court's treatinent of the first amendment issue, but is consistent with subsequent commercial speech doctrine and with first amendment doctrine generally. The Banzhaf court dismissed a claim that the fairness doctrine would chill the speech contained in the cigarette advertisements, arguing that "[t]he speech which might conceivably be 'chilled' by this ruling barely qualifies as constitutionally protected 'speech.' " 405 F.2d 1082, 1101. The court concluded that "[p]romoting the sale of a product is not ordinarily associated with any of the interests the First Amendment seeks to protect." Id.

In context, this argument was very weak to begin with; the court never really attempted to explain how speech that stated a position on a matter of public interest could not be associated with first amendment interests. The court was able to avoid the issue ouly because Banzhaf predated Vinginia Board. In the post-Virginia Board world the court's assertion is simply untenable.

318. Capital Broadcasting, 333 F. Supp. at 587 (emphasis added) (citation omitted). 
page is the name of the product, we simply cannot say the advertisement does not communicate ideas. The advertisement at least conveys the idea that people (im this case men, though that need not always be so) who own the product are fashionable and therefore become more sexually attractive.

Similarly, to borrow an example from Professor Lowenstein, ${ }^{319}$ a cigarette advertisement showing nothing more than a seductively dressed woman imploring the reader to "Light my Lucky" quite obviously invites the reader to behieve that purchasing the brand of cigarettes advertised will make the reader sexually attractive. ${ }^{320}$ Prospective consuniers are free to evaluate these ideas and agree or disagree with them. Their decision may or may not be reflected in the purchase of the products. Regardless of that decision, the ideas are in the public domam for consideration-and they were put there solely by the advertisements. ${ }^{321}$ Whether we agree or disagree with the ideas, we cannot honestly deny their existenee.

Professor Lowenstein has attacked this argument most recently, as part of his larger effort to justify an absolute ban on cigarette advertising. ${ }^{322}$ Professor Lowenstein argues that the commercial speech cases may be understood by examining the inforinational content of the advertisements at issue in each case. ${ }^{323}$ Thus, for Lowenstein "[t] the question comes down to whether one conceives all or virtually all commercial speech as informational." $324 \mathrm{He}$ accurately perceives this to be "a normative question, turning on what one is willing to count as inforina-

319. The example is taken from Lowenstem, supra note 287 , at 1221.

320. Hopefully, it is obvious that these examples, while unfortunately typical, also are outrageously sexist. By treating women as objects of enticement, arguably on a level no higher than the commodity advertised, they convey a message about the role of women in society, or at least about the acceptability of such treatinent, as they convey a message about the product.

Such treatment, while surely objectionable on moral and philosophical grounds, may or may not be regulable as denigrating to women (though $I$ am inclined to think it is not). Quite apart from that discussion, however, it is very important to recognize that the advertisements do convey such messages, and it is a legitimate topic of debate to argue about whether to constram such practices. I treat the subject in a footnote here not because it is less important than the solicitation in the advertisement, but because it is probably not the message the advertiser hopes consumers will perceive, and that hope is probably realized.

321. The rationality of this decisionmaking process is discussed in infra text aecompanying notes 348-51.

322. This effort amimates Professor Lowenstem's article, and his views on commercial speech. Professor Lowenstein proposes as a standard that "[a]ny doctrine or theory that leads to the unconstitntionality of a cigarette advertising ban is madmissible and inust either be modificd or rejected." Lowenstein, supra note 287, at 1207.

323. Id. at 1208. Here Lowenstem uses "information" in roughly the same sense as this Comment does. Thus, for Lowenstein, a section on the protection of "persuasive commercial speech" is surplusage, simce it is not "informational" and therefore not entitled to protection.

324. Id. at 1226. 
tion" " rather than a strictly empirical enquiry. ${ }^{325}$

Lowenstem's argument might shed light on a factor that may make any given advertisement under review more or less palatable to the reviewing court. As an explanation for the commercial speech cases, however, and as a normative construct, the argument ultimately fails. ${ }^{326}$ First, the Court's frequent failure carefully to review the actual content of the speech hinders the argument. Thus, for example, Professor Lowenstem must assume the advertisements in Posadas were "largely noninformational." 327

On a more fundamental level, however, the argument errs in comparing the informational content of speech in cases where regulations of commercial speech were upheld to some unspecified norm, rather than to the informational content of speech in cases where regulations were stricken. ${ }^{328}$ Thus, the argument cannot explain why the "for sale" sigus in Linmark ${ }^{329}$ and the sigus advertising the availability of contraceptives in Carey v. Population Services International ${ }^{330}$ received protection while the trade names in Friedman v. Rogers ${ }^{331}$ and the advertising in Posadas did not. Indeed, the argument's forced assumption that the advertisements in Posadas were noninformational is plainly misplaced, since the regulation at issue there prohibited all forms of commercial speech aimed

325. Id.

326. Professor Farber agrees with this conclusion, although he does not make his analysis explicit. See Farber, supra note 144.

327. Lowenstein, supra note 287 , at 1230.

328. Id. at 1229-30.

329. Linmark Assocs. v. Township of Willingboro, 431 U.S. 85, 92-93, 97 (1977).

330. 431 U.S. $678,700-02$ (1977).

331. 440 U.S. 1, 18-19 (1979). Professor Lowenstein's treatment of Friedman is contrary to the facts of the case. He classifies the speech at issue as noninformational speecl, a classifieation that supports his argument's view of informational content as a decision rule. To bolster this conclusion, he cites Friedman's statement that trade names convey no "intrinsic meaning." Lowenstein, supra note 287, at 1229 (quoting Friedman, 440 U.S. at 12). The passage froin which the quotation is taken, lowever, also recognizes that trade names convey information about prices and the nature of serviees once the name becoines associated in the public mind with a level of service or standard of quality. Friedman, 440 U.S. at 12.

Indeed, the opinion later expressly equates such associated trade names with the informational cominercial speech at issue in Virginia Board and Bates:

[A] trade name conveys information only because of the associations that grow up over time between the name and a certain level of price and quality of service. Moreover, the information associated with a trade name is largely factual, concerning the kind and price of the services offered for sale. Since the Act does not prohibit or limit the type of informational advertising held to be protected in Virginia [Board] and Bates, the factual information associated with trade names may be coinmunicated freely ... to the public.

Friedman, 440 U.S. at 16.

The ban on trade names in Friedman was not limited only to those names that liad not taken on such informational claracteristics. Rather, it was a prophylactic measure aimed at preventing the deceptive use of such names. Id. at 13. Therefore, it is wrong to consider Friedman an example of a regulation of noninformational advertising. 
at Puerto Rican residents. ${ }^{332}$ On its face, the regulation left no room for distinctions based upon the informational content of the speech.

Finally, the theory fails entirely with respect to Fox, where the students received information regarding product purchases and educational information. ${ }^{333}$ In fairness, the Court decided Fox after Professor Lowenstein wrote his article, and it may reflect doctrinal retrenchment more than a flaw in his theory. Still, to the extent his conclusions rest upon the ability of his theory to explain the cases, those conclusions appear tenuous.

These problems notwithstanding, Lowenstein's arguinent would hold that the ideas described in the examples set out above do not constitute information of any kind, at least for first amendment purposes. This conclusion supposedly is inandated because any other conclusion would render the phrase "commercial speech" tautological when used in conjunction with the term "information." 334 There is reason to doubt this is the case, at least at a pragmatic level. ${ }^{335}$

The arguinent, however, may be disproved without reference to informal logic. At one level, the argument fails because it does not take its conclusion seriously. The argument is not that cigarette advertisements, or other, similar, persuasive commercial speech, convey no information, and therefore may be suppressed without loss. Rather, it is that consuiners will accept the ideas and associations conveyed by such speech and act on them by purchasing cigarettes. The crux of the argument assumes that such ideas and associations do not constitute "information" for first amendment purposes, an assumption that cannot be maintained.

332. Posadas, 478 U.S. at 335,337 (quoting the Puerto Rican Superior Court's narrowing construction of the original statute).

333. Board of Trustees v. Fox, 109 S. Ct. 3028, 3032-33 (1989). It is also only fair to note that in Fox the Court ostensibly refrained froin deciding whether the regulations at issue could be applied to commercial speech because it had to remand the case to the district court for factual findings. Id. at 3037-38. Nevertheless, the Court found that the speech was commercial, and that the governmental interest asserted by the university was substantial. Id. at 3032 .

Having decided these issues, and that Central Hudson does uot require a regulation to be the least restrictive uneans to achieving a governmental end but, rather, only a mcans reasonably related to achieving such an end, id. at 3032-35, the only issue left to address is whether the regulation directly advances the asserted governmental interest. Given the prior treatment of this eleunent in Posadas, 478 U.S. at 341-42, we are entitled at least to express skepticism about the prospects for a successful challenge to the statute on remand. Additionally, it is at least worth noting that the Court felt comfortable classifying the commercial speech cases by reference to the breadth of the regulations at issue in each case, rather than by informational content. Fox, $109 \mathrm{~S}$. Ct. at 3036-37.

334. Lowenstein, supra note 287 , at 1227 n.76.

335. At an abstract level, the argument is correct. The argument, however, also is largely irrelevant. It means nothing more than that first amendinent protection for commercial speech cannot be justified by an argument from information simpliciter. While true, the point carries no weight against arguments correlating such informational value with the overall value structure of the first amendinent. 
First, the argument rests upon a contrived definition of "information." The argument defines information in the commercial speech context as "information that is likely to provide assistance to a consumer in making a rational purchasing decision."336 Thus, the argument limits information in the commercial speech context almost exclusively to factual statements regarding products and prices, which may be evaluated for their truthfulness. Advertiseinents containing only images or associations contain no information in this sense. ${ }^{337}$

This definition, however, rests upon an overly narrow conception of what makes a decision rational. For example, what are we to say of a person who knows that she has a very strong desire to purchase a product, and can weigh that desire rationally in a fully articulated cost-benefit analysis but who has no idea why she has such a desire? Lowenstein's argument completely ignores self-realization as a legitimate first amendment value, which can be served by speech that does not reinotely reseinble the informational speech contemplated by the argument. Moreover, Lowenstein's definition simply has no normative basis; in no other area of first amendment doctrine would speech that conveyed opinions or associations be deeined noninformational.

This definition, however, yields precisely that result. To the extent the definition excludes values legitimately protected by the first amendinent, it is invalid. Simply put, speech has never been considered outside the scope of the first amendinent siniply because it appeared in the form of an opinion or an association. ${ }^{338}$ And it is only the form of the advertisements to which the argument objects. ${ }^{339}$

Because the definition has no normative support, it inust seek support as an accurate description of what the Court actually does. Thus, it necessarily draws its credibility from Professor Lowenstein's contention that information so defined is the key to explaining the commercial speech cases. As the foregoing analysis demonstrates, however, that contention is incorrect and cannot support the definition. Whether an advertisement that conveys to a consumer the idea that sinoking will make her more sexually attractive contains "information" similar to price and location advertiseinents is irrelevant. As estabhshed above, the commercial speech cases do not delnand that such distinctions be drawn, and the distimction has no norinative force of its own: the fact that some speech contains such information while other speech does not tells us ouly that the speech is different. Thus, Professor Lowenstein's contention that

336. Lowenstein, supra note 287 , at 1235 .

337. Id. at 1221-22.

338. In fact, opinions generally are afforded greater first amendment protection than assertions of fact, because opurions are not subject to restriction on the ground that they are potentially false.

339. See infra text accoinpanying notes 349-50. 
"[t]he price of drug information is information and 'Light my Lucky' is not" ${ }^{\prime 340}$ is inaccurate.

This argument raises two additional issues that help clarify the relationship between commercial speech, rationality, and self-realization. The first issue arises from Professor Lowenstein's argument that because cigarette advertisements are manipulative, they cannot aid in the development of rationality. ${ }^{341}$ Apparently, he therefore would consider a decision based upon acceptance of the ideas set forth in such advertisements as "irrational."

This position is untenable for three reasons. First, and inost important, the position wrongly assumes the government can determine, in the context of persuasive commercial speech, which decisions are and are not rational. The ideas conveyed by niany advertisenients, including both examples used here, are not and never will be susceptible of such a determination. Simply put, the government is and always will be incapable of deciding what nıakes a person sexually attractive, chic, or sociable; such determinations are inherently subjective. And unless the government decides that cigarette sinoking, for example, does not do so, it cannot say a decision accepting the contrary view is irrational.

The second reason to reject this proposition is that it portrays too narrow a view of rationality. Even where an advertisement sets forth what may be classified as an opimion (smoking brand $\mathrm{X}$ makes you sexy) ${ }^{342}$ that works subliminally on niany people, it may work in an expressly rational way on others. For example, a person who relaxes when she smokes cigarettes may have niade a rational judgment that the relaxation she gains by snioking is worth the health risks involved. ${ }^{343}$ The same person also may rationally decide that she desires to be associated with the attributes of smoking portrayed $\dot{n}_{1}$ advertisenients, and that this desire outweighs the health risks involved. ${ }^{344}$

The final reason to reject this proposition is that it objects to the form of the advertisenients as much as the content of the ideas expressed. Specifically, if an advertisenient simply stated "snıoking nıakes you sexually attractive," with the name of a tobacco company appended, the idea

340. Lowenstein, supra note 287 , at 1235.

341. Lowenstein states cigarette advertisers "inake no pretense of appealing to rational deliberation and are imbued with the most manipulative techniques conteinporary social sciences makes possible." Id. at 1222.

342. I an here using opinion in the sense of a dichotomy between statements of fact and statements of opinion. This dichotomy, borrowed from defamation law, is explored more fully in Part IV, infra. Lowenstein accepts, at least in part, this characterization of the Lucky Strike advertisement: 'But the words 'Light iny Lucky,' stated by a young woinan staring straight at the reader, are neither truthful nor misleading. They are not truth-evaluative at all." Id. at 1231 .

343. I owe this example to Russ Dees.

344. In the latter example the woman would be doing no more than Professor Lowenstein does-assuming advertisements are successful in linking sinoking with various desirable attributes. 
would be the same as in the Lucky Strike example. The idea simply would not be conveyed in as persuasive a manner.

Yet the use of image associations is not unique to commercial advertising. It is, for example, employed widely in political campaigns. A photograph of a candidate in front of a war memorial or a commercial showing the candidate touring a flag factory conveys the idea that the candidate is a patriot, an idea that also could be conveyed by the simple statement "candidate $X$ is a patriot." Unless we are willing to condemn as irrational a vote for candidate $\mathrm{X}$ based upon the patriotic images, we cannot condemn as irrational an econo1mic decision to purchase cigarettes to enhance sex appeal. ${ }^{345}$

Thus, persuasive commercial speech should not be demied full first amendment protection because it does not contribute to the first amendment rationality value. The arguments in favor of such a view are weak, and there is no reason that only speech that serves the rationality value should be entitled to first amendment protection. Speech that serves the self-realization value also is entitled to such protection, and persuasive speech falls into that category. Persuasive commercial speech contributes substantially to consumers' perceptions of themselves and the world around them. A person who perceives advertisements such as the examples above niay enibrace the ideas communicated in those advertisements as part of their own self-perception or self-expression. ${ }^{346}$ Thus, a businesswonian may perccive herself to be successful when she is able to afford a certain car or buy clothes from a certain designer, and a parent may fecl that she is a better parent for buying her child a toy seen on television or giving the child a specific medicine. In each case, the perceptions may well be fostered, if not created, by purely persuasive conniercial speech. ${ }^{347}$

In this sense, commercial speech nay go beyond fostering rational thought processes to create aspects of an individual's perception of herself, of others, or of the world at large. Thus, Professor Redish's carly

345. This argument appears similar in form to the kind of "slippery slope" arguments I recognize as tenuous. See supra text accompanying note 282. This argument, however, is more appropriately characterized as an argument froin overbreadth. That is, we should reject the proposition that decisions based upon image advertising are irrational because that proposition would condemn decisions, such as voting, that the government should not atteinpt to characterize as rational or irrational. See Schauer, Slippery Slopes, 99 HARV. L. Rev. 361, 366 (1985).

346. See Post, Social Foundations, supra note 273, at 962.

347. See also Spencer \& Phillips, The Macho Image, or Why We Drive ORV's to Work, Washington Post, July 1, 1989, at A17, col. 1.

Image buying has become specific and refined; smoking a Marlboro cigarette says one thing about you, smoking a Newport another; drinking a long-neck Budweiser means one thing, drinking a Heineken another. The assumptions now made about a BMW or a MercedesBenz owner are almost automatic.... [A]dvertising now stamps almost every product with an image.

Id. 
view that commercial speech enhances self-realization through the mechanism of rationahty may not have gone far enough; commercial speech fosters self-realization directly.

Many people, of course, would consider this aspect of commercial speech quite differently: they would call it manipulation, subliminal or otherwise. Indeed, Professor Lowenstein beheves that "[a]dvertising that eschews information and appeals subtly to emotions ... may also induce unwise purchases. If widespread, such advertising may adversely affect public and private values by imposing upon a very substantial portion of our public discourse a uorm of manipulation of imdividuals for profit."348

Taking this stateinent as a fair characterization of the argument, several things are readily apparent. First, as noted above, at one level this is an argument about the form of the advertisement, not its message. Thus, if we are to hold the argument to its premises (unarticulated though they may be) we must condemn all decisions based upon such subtle emotional appeals, including decisions made in almost every recent presidential election. ${ }^{349}$ Of course, we are not about to do this, at least partially because in pohtics we do not trust the government to determine what is a wise pohtical choice, or when we are being manipulated into choosing against our best interests. Briefiy stated, we fear paternalisin in electoral politics. The argument advanced above, however, claims not to be paternalistic-citing as authority the Court's actions in several cases, particularly Posadas. ${ }^{350}$

At most this proves the Court has failed to use the commercial speech doctrime to strike down paternalistic regulations. It does not prove such regulations are not paternalistic. Given Professor Lowenstein's definition of paternalism- "specch restrictions intended to protect the consumer aganist his or her own imprudent action" ${ }^{351}$-it is hard to see how an argument working from the premise that people will not realize what they are doing and, therefore, will make bad choices, will result im any other kind of regulation. It is even harder to see what normative basis the government could adopt to define choices in this area as good or bad.

From this perspective, even assuming the argument correctly characterizes persuasive commercial speech as manipulative, the choice is not between manipulation and freedom from manipulation. The choice is between mainpulation by private commercial speakers and manipulation, as in Posadas, by the government. At least the former option offers the

348. Lowenstein, supra note 287 , at 1231.

349. See Oreskes, What Poison Politics Has Done to America, N.Y. Tìnes, Oct. 29, 1989, § 4, at 1.

350. See Lowenstein, supra note 287 , at $1242-43$.

351. Id. at 1238 . 
chance that some competition anıng manipulative speakers, a marketplace of subliminal ideas, will arise, and such competition seems intuitively preferable im any given case to a governmental manipulation monopoly.

Therefore, advertising implicates rationality and self-realization interests in at least four ways: advertising allows consumers to make rational choices among goods and services, it allows consumers to make decisions regarding the propriety of regulating certain activities, it presents ideas to consumers regarding the nature and potential of the subject of the advertisement, and it may help create portions of each individual's self-perception. Assuming that rationality and self-realization are values fostered by the first amendment, we should grant commercial speech full first amendment protection unless there is a very good reason not to do so. ${ }^{352}$ Several such reasons have been asserted, and they are the focus of the next Part. ${ }^{353}$

\section{IV}

\section{The Opposition to Protecting Commercial Speech}

The arguments agaimst granting first amendment protection to commercial speech, or in favor of granting only a very limited level of protection, have arisen in a haphazard manner from the line of cases discussed in Part I. Those arguments may be placed into four categories: (1) the argument that commercial speech is at the "periphery" rather than the "core" of the first amendment; (2) the argument that the greater power to regulate an econoric activity includes the lesser power to regulate speech about that activity; (3) the argument that protection for commercial speech revives the discredited econormic due process doctrine; and (4) the argument that granting full protection to commercial speech will dilute the level of protection granted to other speech.

This Section contends that each of these arguments is flawed. Neither individually nor collectively do they provide persuasive reason for granting lesser protection to commercial speech.

352. Professor Schauer characterizes this process as the difference between "defining in" different kinds of speech (assuming no speech is protected by the first amendment and then extending protection to different types of speech if there is a good reason to do so) and "defining out" such speech (assuming all speech is protected and then looking for reasons to exclude different types of speech). Schauer, Categories, supra note 148, at 281. The Court in Virginia Board followed the "defining out" method.

353. By providing an intermediate level of first amendment protection, the Court, to some extent, has sidestepped this issue. The Court's declaration that commercial speech deserves only an intermediate level of first amendment protection, more the product of fiat than analysis, eliminates the need to ask whether commercial speech serves legitimate first amendment values and, therefore, might be entitled to a higher level of protection. 


\section{A. The Core-Periphery Conundrum}

Both the Court ${ }^{354}$ and commentators ${ }^{355}$ have asserted that commercial speech falls outside the "core" of speech protected by the first amendment. As commonly stated, this argument makes several important assumptions. When these assumptions are examined, the conclusion that commercial speech hes outside the "core" of first amendment protection appears unwarranted.

First, the core/periphery argument assumes that the first amendment protects an ascertainable "core" of speech. This assumption in turn rehes upon our ability to define the field from which a core is selected. For example, the "core" could be derived from the dictionary (the hundred or so most important words), or from our history (speech we traditionally protect), or from any one of a number of other sources.

If the concept of the core is to aid in first amendment analysis, its contents must be derived from the field of values protected by the first amendment. Those values, and the need to protect them, are presumably

354. See Ohralik v. Ohio State Bar Ass'n, 436 U.S. 447, 456, 459 (1978); supra text accompanying notes 66-67.

355. E.g. Schauer, Architecture, supra note 8, at 1185-88. Professor Schauer rejects any single, unitary justification for the first amendment, preferring to cast the amendment in terms of "several cores, explainable largely in terms of clusters of communicative conduct with respect to which government has deinonstrated such- a proclivity toward overregulation that compensatory underregulation is now necessary." Id. at 1186.

As examples of "cores," Professor Schauer lists ideological communication (including political and religious communication), literary and artistic communication, and academic and scientific communication. Id. Yet if these cores are themselves to be arranged hierarchically in terms of first amendment importance, the need for a unifying theory of the first amendment is not obviated, because the hierarchy must be justified by reference to a value that subsunies all the cores. Moreover, if the cores are not to be arranged hierarchically we cannot determine which cores are nearer to the center and which are nearer to the periphery. Thus, even when we know which core commercial speech is in we have no way of determining its relative placement.

Alternatively, Professor Schauer's construct could be cousidered entirely enpirical. This would be consistent with his reference to a governmental propensity to overregulate certain speech. Id. at 1185-86. As actually applied to speech, however, an empirical approach leaves us with several questions. For example, we cannot tell what speech has been regulated excessively, and therefore is entitled to coinpensatory underregulation, without reference to some norm or norms defining what level of regulation is appropriate for each type of speech considered a candidate for core status. Such a norm or norms make sense only if taken from the values the first amendment seeks to protect. Thus, the need for an overarching value of the first amendment remains.

Finally, the multiple cores approach tells us relatively little about what constitutes a core. Thus we cannot know if commercial speech should be a core unto itself, or alternatively, should not be considered speecli at all. These problems are inherent in topic-based approaches, which is probably the best way to describe Professor Schauer's "clusters of communicative conduct" (the alternative way would be motive). These problems are, however, alleviated somewhat when we define the cores to be the values protected by the first amendment. In that case the normative problem is lessened, and tools such as consideration of prior governmental overregulation may be employed within the framework of each value. The discussion here assumes a single "core" of speech, rather than Professor Schauer's alternative. 
the reason for the amendment in the first place. ${ }^{356}$ Moreover, even when asserting that commercial speech is outside the core, the Court purports to be engaging in a value-based analysis. Thus, in Ohralik, (and therefore every case since) the Court spoke of the "subordmate position" of cominercial speech "in the scale of First Amendment values."357

Therefore, the argument assumes one of thrce things. Either the first amendment protects only one value, we can rank hierarchically the values protected by the first amendment, or, regardless of the resolution of the first two questions, we can rank speech hierarchically within a given value. The third assumption works with either of the first two, but as to them we must pick one. Thus far the argument seems safe-as long as we can articulate good reasons for whatever single value or hierarchical order we choose, we can make such a choice or construct such a hierarchy. When this assumption is examined in tight of the argument as it pertains to eommercial speech, however, certain problems become apparent.

If commercial speech directly fosters the rationality and self-realization values protected by the first amendment, the core/periphery argument inust demonstrate either that those values are less important than other first amendment values (which then would comprise the "core") or that commercial speech fosters those values less well than do other types of speech. I do not believe either of these propositions can be proved. At a minimum, those who would place commercial speech in the periphery of the first amendment have not fully addressed these propositions. ${ }^{358}$

First, recall that Justice Brandeis' famous concurrence in Whitney $v$. California ${ }^{359}$ placed the rationality value and the self-realization values among those protected by the first amendment. ${ }^{360}$ For Justice Brandeis the rationality value played a dual role-as an end in itself and as a

356. This may or may not be true purely as an historical matter. Nevertheless, the mode of first amendment reasoning since at least Justice Brandeis' concurrence in Whitney follows this structure.

357. Ohralik, 436 U.S. at 456.

358. Having earlier cited Professor Schauer as one who would place commercial speech in the periphery, see supra note 67, I must point out here that he did not purport to analyze the theoretical underpinnings for this conclusion. Rather, he assumed commercial speech was a peripheral form of speech for purposes of his broader architectural discussion. Schauer, Architecture, supra note 8, at 1185-87.

359. 274 U.S. 357 (1927).

360. The passage from Whitney reads:

Those who won our independence believed that the final end of the State was to make men free to develop their faculties; and that in its government the dehiberative forces should prevail over the arbitrary. They valued hiberty both as an end and as a means. They believed liberty to be the secret of happiness and courage to be the secret of liberty. The belief that freedom to think as you will and to speak as you think are means indispensable to the discovery and spread of political truth; that without free speecli and asseinbly discussion would be futile; that with thein, discussion affords ordinarily adequate protection against the dissemination of noxious doctrine ....

Id. at 375 (Brandeis, J., concurring). 
necessary prerequisite to informed self-government. ${ }^{361}$ With only shightly greater effort, we can see the form of the self-realization value as well. ${ }^{362}$

Although the frequent references to Justice Brandeis' views in Whitney can inake the search for first amendment values seem hike a jurisprudence of original intent beginning in 1927, if we take his expression as an acceptable starting point we see that the first amendment does im fact imphicate the rationality and self-realization values. Indeed, taking perhaps a shightly broader view of "faculties," one could argue plausibly that rationality and self-realization are core values, since their realization is "the final end of the State."363 This argument, of course, consistently has been rejected, originally by Alexander Meiklejohn ${ }^{364}$ and perhaps most notably (at least of late) by Robert Bork. ${ }^{365}$ A brief analysis of his argument on this point sheds further hight on the nature of the core/periphery argument.

The key to Judge Bork's argument, and the related arguinents of other commentators, is the contention that because we desire to afford more extensive protection from governmental interference to speech activity than to other activity, there must be something special about speech that justifies such extra protection. ${ }^{366}$ Judge Bork utilizes a very strimgent standard in making this determination: for him the special element justifying greater protection of speech also must be uinque to speech alone. Thus, he concludes only speech that fosters the value of discovering and disseminating political truth deserves special protection. ${ }^{367}$

The strong version of the umiqueness argument has been thoroughly debated, and I cannot improve on that dialogue here. ${ }^{368}$ For present purposes, it is enough to note that there is no reason to beheve that speech must have unique properties to warrant protection. As Professor Greenawalt has noted, "speech may well be thought to promote development of happimess in different ways (or more consistently) than non-

361. Id.

362. This sighting is taken primarily from a combination of the rationality interests and the references to hberty and freedom of thought. See also Stone, Content-Neutral Restrictions, 54 U. CHI. L. REV. 46, 56 n.44 (1987).

363. Whitney, 274 U.S. at 375.

364. See Meiklejohn, The First Amendment Is An Absolute, 1961 SuP. CT. REV. 245, 255.

365. Bork, Neutral Principles and Some First Amendment Problems, 47 IND. L. J. 1 (1971).

366. Id. at 23.

367. See id. at 31 .

368. For an excellent criticism of Judge Bork's overall position, see Shiffrin, supra note 147, at 1234-39. Professor Shiffrin points out that, as advanced by Judge Bork, this argument really is the prodnct of preexisting notions about the role of judges and about the nature of democracy. Id. at 1234-36. He proposes an alternative construct that eschews any effort to ascribe to the first amendment any single, inclusive value that explains why we want to protect speeeh and which can be referred to in order to judge any given speech regulation. Id. at 1283 . 
speech activities."369 Additionally, regardless of the outcome of the uniqueness debate, the rigidly instrumental view of democratic self-governance as an adequate justification for the first amendment fails because that justification is, ultimately, incoherent. ${ }^{370}$

If the value of discovering and disseminating political truth does not he alone at the core of the first amendment, the first assumption outlined above is false. 371 Thus, for the argument to liold true we must determine that we can arrange hierarchically the values protected by the first amendment. There is no reason that we cannot do so, provided we can isolate criteria sufficient to determine the relative importance of each value. And that, of course, is the problein. Sucl criteria necessarily must be able to ineasure the wortli of each value and therefore, at least in that sense, subsume them all. The wortl of tle values, however, may not be reducible to the common denominator necessary for coinparison. ${ }^{372}$

All this is in one sense unnecessary for, as Professor Schauer points out, "although there is no reason why there miglit not be only one justification, nor is there any reason why tlie first amendment might not be the phrase encompassing several different justifications not reducible to any single principle."373 In otlier words, we need not necessarily compare first amendment values against one another in order to isolate some ultimate value, or even to arrange thein in some sort of hierarcliy.

Rather, we can assume that all speech that enhances a first amendment value is potentially deserving of first amendment protection on that ground. The task then becomes to draw the line within each value separating protected from unprotected speecl in a principled way, thus imphcating the argument's third assumption-tliat speech inay be hierarchically arranged within eacli of the values protected by the first amendinent. Given this assumption, we would expect arguments about it to focus upon the differential importance of various types of speech, as

369. Greenawalt, Speech and Crime, 1980 AM. B. Found. REs. J. 645, 734 n.344. Additionally, Professor Redish has noted Bork's argument fails by its own terms, because nonspeech activities, such as terrorism and assassination, also convey pohtical messages. Redish, The Value of Free Speech, supra note 267, at 599.

370. See Post, supra note 201, at 670-71.

371. The Court frequently indicates that political speecl is the most important kind of speecl. Thus, if the instrumental value served by pohtical speech does not he alone at the core of the first amendment, we may be relatively certain that, at least from the Court's perspective, no other value lies alone at the core of the first amendment. Such a conclusion would imdermine the centrality of political speech in the Court's scheme of things.

372. This is essentially the problem Professor Shiffrin notes with the metaphor of balancing as applied to values. Shiffrin, supra note 147, at $1249 \mathrm{n} .240$ ("the balancing metaphor implies that all values can ultimately be reduced to one measuring standard").

373. Schauer, Architecture, supra note 8, at 1186. I am here assuming that my use of values and Professor Schauer's use of "justifications" is the same. In that respect, I envision a justification as Professor Schauer uses the term to be an argument for protecting speech that is supported by reference, implicit or explicit, to a value. 
judged by the degree to which that speech fostered the value it imphcated. Under this assumption, we would have a core of speech for each value, presumably the speech that was most important to the realization of that value. Thus, one act of speech could imphicate several different values, each to different degrees.

Of course, the core/periphery argument, as presented by both Judge Bork and the Court, looks like nothing of this sort. Judge Bork's version of the argument illustrates the point. Judge Bork's argument purports to be an argument about first amendment values, particularly the value inhering in the discovery and dissemination of political truth. ${ }^{374}$ The argument, however, takes place at a much less abstract level: it is an argument about speech topics, not speech values. Specifically, for Judge Bork the category of protected speech consists of "speech concerned with governmental behavior, pohicy or personnel .... Exphicitly pohtical speech is speech about how we are governed."375 Therefore, the first amendment does not protect "scientific, educational, commercial or hiterary expressions as such. A novel may have impact upon attitudes that affect politics, but it would not for that reason receive judicial protection." 376

Indeed, Judge Bork expressly disassociates his argument from a value-based theory, since "the rationale of the first amendment cannot be the protection of all things or activities that influence political attitudes. Any speech may do that, and we have seen that it is impossible to leave all speech unregulated." ${ }^{377}$ Thus, Judge Bork actually rejects the premise that the relevant core must be drawn from first amendment values. ${ }^{378}$ The Court does the same thing, frequently referring to "core" speech as pohitical speech. ${ }^{379}$

But political speech, at least as used by Judge Bork and the Court, is simply speech about politics, which is snnply one topic out of hundreds upon which one might wisl to speak. Why a topic of speech should be considered the core would be mysterious in any but the most rigidly consequentialist of first amendment regimes. After all, the Court says that it

374. Bork, supra note 365 , at 26 . These may well be two different values with vastly different implications. For present purposes, liowever, it is not necessary to divide them.

375. Id. at 27-28.

376. Id. at 28.

377. Id. (emphasis added).

378. Altlough it comes up in a slightly different context, this rejection is the basis for Professor Shiffrin's criticism that "[l]urking behind Bork's devotion to principle . . . is a commitment to relativism and utilitarian preference-maximizing." Shiffrin, supra note 147, at 1237. As Professor Shiffrin concludes, "[i]f a case for excluding commercial speecl from first amendment protection is to be made, it must come from an understanding of first amendment values, not from reflection about the judicial role." Id.

379. See, e.g., Ohralik v. Ohio State Bar Ass'n, 436 U.S. 447, 456 (1977). 
is dealing with a hierarchy of values, not topics. ${ }^{380}$

More importantly, it seems anomalous to say that we have the first amendment because without it we could not talk about politics. That topic clearly plays a role in explaining the importance of freedom of speech, but it does so ouly when we explain why it is important to talk politics; and the answer to the question of importance takes place at a value level, not a topic level. We may, for example, say that it is important to talk about politics because we seek political truth or wish to engage im reasoned self-governance. Finally, when we adopt a topicbased approach to the core/periphery question we inevitably will fail to protect speech that inay substantially enhance the values of the first ainendinent. As Judge Bork admits, speech on almost any topic may develop political attitudes, and to the extent we resign speech on certain topics to the periphery we lose the benefit of such speecli to the relevant first ainendment values.

The same analysis apphies to the rationality and self-realization values. Any speech that challenges an individual to think has at least the potential to develop the rational capacity of the individual, or to bring that capacity to bear on some problem, regardless of the topic. Law school, for example, purports to enhance rational thought through the use of the Socratic method, exams, lectures, casebooks, outlines and the like. Yet such speech is not overtly political speech as Judge Bork would describe it. The poimt here, once again, is that there is not a "political rationality" separate from "commercial rationality."381 As the passage from Whitney indicates, we are concerned here with capacity-the capacity to reason and develop our liberty and happiness. ${ }^{382}$ This capacity nay be developed and exercised by a political cainpaign commercial one mimute and an autolnobile commercial the next. The topics and results inay differ, but the differences are not relevant at the level of capacity. ${ }^{383}$

With this background, it should be evident that commercial speech directly contributes to rationality and self-realization. Taking into account infornational commercial speech in Professor Lowenstein's sense, together with persuasive commercial speech that communicates ideas or helps formulate self-images, an enormous ainount of commercial

380. See supra text accompanying note 357 .

381. Nor is there a political way to self-realize that is different from a commercial way to selfrealize.

382. See supra note 360 .

383. In addition to these somewhat theoretical arguments, the core/periphery problem would take on a drastically different look if the Court abandoned its treatment of commercial speech as a negative number. See supra text accompanying notes 195-99. In that event, the mixed speech cases would no longer be commercial speech, they would be core cases, or at least candidates for core treatment. 
speech fosters the rationality and self-realization values. ${ }^{384}$

Therefore, we return to Professor Lowenstein's search for noninformational speech or, properly stated, commercial speech that does not enhance rationality or self-realization. To the extent such advertisements may be identified, a lesser degree of protection would be appropriate. The Court, however, would have to analyze the relevant speech under this paradigm, and extend lesser protection ouly to speech that did not foster either value (or any value imphicated by the first amendment). Thus, the tough questions for the Court would be at what level speech must contribute to the relevant value to be entitled to first amendment protection. Currently, the Court does nothing of the sort. Rather, it invokes commercial speech as a talisman, without regard for the imphications for underlying first amendment values. ${ }^{385}$

The core/periphery argument fails because it cannot justify any of its necessary assumptions, at least one of which is critical to its success. Therefore, if the lesser protection afforded commercial speech is to be justified, it must be on a different ground.

\section{B. The Greater Power/Lesser Power Argument}

The Court's most recent and most troubling justification for giving lesser first amendment protection to commercial speech is the argument that the greater governmental power to regulate an underlying economic activity necessarily mcludes the lesser power to regulate advertising concerning that activity. ${ }^{386}$ The Court used this argument to reach the result in Posadas, an opimion written by then-Justice Rehnquist, the primary advocate of the argument. ${ }^{387}$

Two mam poimts may be raised against this argument, either one of which is sufficient to reject it as a basis for denying protection to com-

384. In this regard, the Court's observation that price information may be more important to the average consumer than the current political debate reinforces the argument that commercial speech may play an irreplaceable role in fostering rationality. Though the observation applies to only one form of rationality, at least as to that form the Court's insistence upon lesser protection for commercial speech appears especially inappropriate. See Virginia State Bd. of Pharmacy v. Virginia Citizens Consumer Council, Inc., 425 U.S. 748, 763 (1976).

385. Commercial speech does not fit precisely into this analysis. At one level, commercial speech analysis tends to be topic oriented, because most of the cases tend to concern goods or services-the relevant topics. As discussed at length above, however, the definition of commercial speech turns largely on the profit motive involved. This does not pose a problem for the analysis here because speech generated by any motive has the ability to foster values protected by the first amendment in the same way that speech on any topic has that ability. Motive and topic are alike in that they are both largely irrelevant to first amendment values.

386. As noted earlier, the Court has come full circle on this argument. See supra text accompanying notes $102-05$.

387. As Professor Tribe has noted, Chief Justice Rehnquist utilizes this form of argument throughout his jurisprudence. See L. Tribe, AmErican Constrtumonal Law 903 n.84 (2d ed. 1988). 
mercial speech. First, as noted in Part I, the argument views commercial speech as merely another form of economic activity, such as growing apples or manufacturing chemicals, rather than as speech. ${ }^{388}$ Otherwise, the argument could not justify regulation of what looks and sounds like speech merely by reference to the power to regulate commercial conduct.

Put another way, the power to regulate the conduct can be considered a greater power vis-à-vis speech only if the speech is considered merely a subset of the conduct. ${ }^{389}$ Thus, if we again view commercial speech as existing on a continuum, the greater power/lesser power argument would be valid only as to verbal acts-which are ways of doing things instead of saying things. Beyond this relatively narrow range on the continuum, however, the argument is not valid.

A couple of hypothetical applications of this rationale outside the commercial speech area will clarify this conclusion. The government's "greater" power to control the conduct of elections and counting of ballots never would be construed to include the "lesser" power to regulate speech made im contemplation of an election. Similarly, the "greater" power to build or not to build a public hbrary never would be considered to include the "lesser" power to regulate by their viewpoint the books placed upon its shelves. This is not, of course, to say that such speech inay never be regulated. If the campaign speech or the library books were regulated, however, it would have to be by reference to first amendment doctrine and not by reference to the power of the government to establish a polling place or build a bookshelf.

The converse analysis also demonstrates the point. In Posadas, then-Justice Rehnquist attempted to distinguish tlie speech in Carey and Bigelow by arguing that in those cases "tlie underlying conduct that was the subject of the advertising restrictions was constitutionally protected and could not have been prohibited by the State." ${ }^{390}$ But if the advertisements at issue in those cases had been legally obscene they could lave been independently regulated on that basis, a contention Justice Rehnquist almost certainly would not dispute.

Finally, the greater power/lesser power rationale coinpletely ignores the histener interests that justified protecting commercial speech in the first place, ${ }^{391}$ holding them subservient to the government's power to reg-

388. See supra text accompanying notes 113-14.

389. In Posadas, the Court argued that the greater power to ban gambling included the lesser power to ban advertising relating to gambling. This version of the argument is the strongest because if the Court banned gambling it then could prohibit advertising on the independent ground that the underlying activity was illegal. See supra note 30 . Absent the greater action to ban, however, this rationale is inapplicable, and the argument in the text still holds true.

390. Posadas de Puerto Rico Assocs. v. Tourisin Co., 478 U.S. 328, 345 (1986); see supra text accoinpanying notes 299-308.

391. See Virginia Board, 425 U.S. at 763. 
ulate economic activity. Yet the power to regulate economic activity is entirely irrelevant to histener interests. One need only imagine an election official explaining to an audience that because the official will run the balloting therefore she used her included power to cancel a speech to realize that, froin the listener's perspective, the rationale is purely non sequitur.

This ineans that the greater power/lesser power rationale rests upon an untenable assumption. Commercial speech possesses independent first amendment value, and inay not be restricted without acknowledging that value and deinonstrating, in terms of first amendment theory, why the restriction is justified. Yet that is precisely the effect of the greater power/lesser power rationale.

Moreover, the greater power/lesser power rationale is fundamentally inconsistent with the equal proteetion primciples underlying the first amendment's aversion to content and viewpoint discrimination. ${ }^{392}$ This analysis is based upon the principle that, while the government generally is free to classify different things, it may not ordmarily base classifications of speech upon the ideas presented by the speech. ${ }^{393}$ Simply put, the Court cannot use the greater power/lesser power argument to justify uploolding governmental regulations upon advertiseinents while striking down regulations upon speech conveying inessages contrary to those contained in the advertisements. Such action would endorse viewpoint discrimination. Professor Stone aptly described the problein presented by viewpoint discrimination:

Any law that substantially prevents the communication of a particular idea, viewpoint, or item of information violates the first amendment except, perhaps, in the most extraordinary of circumstances ... by effectively excismg a specific message froin public debate, it mutilates 'the thinking process of the community' and is thus incompatible with the central precepts of the first amendinent. ${ }^{394}$

Viewpoimt discrimination problems will be of concern in all coinmercial speech cases involving the expression of ideas. ${ }^{395}$ As one com-

392. Shiffrin, supra note 147 , at 1228 n.8.

393. See Note, Constitutional Protection, supra note 43, at 748 ("Content-based regulations of speech have commonly been reviewed by means of equal protection analysis."). The Note ultimately misapprehends the nature of equal protection analysis in first amendment cases. The Note argues that "equal protection analysis is not applicable where the speech in question does not advance speaker interests. Regulation of such speech does not set up a elassification on which an equal protection analysis can be bottoined." Id. at 749.

Thus, the Note assumes the relevant classification is that of people-speakers or listeners. That should not be the case; the appropriate classification is of ideas. Ideas, arguments, and points of view inust be trcated equally, otherwise governmental regulations might control public discourse.

394. Stone, Content Regulation and the First Amendment, 25 WM. \& MARY L. Rev. 189, 198 (1983).

395. See Note, Constitutional Protection, supra note 43, at 749-50 (noting viewpoint 
mentator has noted, in such circumstances "[t]he government is not only attempting to control the individual's awareness of an option he may pursue . . . but also to control what the individual believes about this option."396 This is precisely the concern expressed by Justice Blackmun in Central Hudson and Justice Brennan in Posadas. ${ }^{397}$ The greater power/lesser power argument ignores this concern entirely and, therefore, cannot be used, by itself, to justify regulations of commercial speech.

The problein of viewpoint discrimination will exist regardless of the justification used to restrict commercial speech. If such a regulation is upheld for any reason, the ideas contained in the regulated speech will be suppressed, while the opposing ideas will not be, so long as they do not take the form of commercial speech falling within the regulation. Thus, if we restrict advertising for easinos, we suppress the idea (or at least one form of expressing the idea) that gambling is fun but allow anti-gambling inessages to persist. ${ }^{398}$

Consequently, to borrow a inetaphor favored by the Court generally, in the marketplace of ideas for recreational activity in Puerto Rico, alternative activities to gambling, whatever they may be, will enjoy a degree of protection from the competition of the pro-gambling inessage. Thus, rather than employ a blanket rationale such as the greater power/ lesser power argument, the Court should scrutinize every commercial speech case to determine what viewpoint effects, if any, are carried by a regulation before it. Few cases will pass inuster under such scrutiny, and those that do pass inuster will not do so on the strength of the greater power/lesser power argument.

\section{The Economic Due Process Argument}

A third argument frequently raised agamst extending full first amendinent protection to commercial speech is that such extension revitalizes the discredited economic due process logic long abandoned by

discrimination problems where the government seeks to control private behavior through commercial speech restrictions).

396. Note, The First Amendment and Legislative Bans of Liquor and Cigarette Advertisements, 85 ColUM. L. REV. 632, 651 (1985) (emphasis in original) (authored by Matthew L. Miller). The Note goes on to argue that the Central Hudson test should be refocnsed to concentrate upon the less restrictive means eleinent. Logically, the Central Hudson test is unnecessary once we recognize the value of commercial spech to rationality and self-realization. We simply may utilize present first amendment doctrine to analyze commercial speech.

397. The argument, of course, did not fare too well in those cases, which is not to say that it is incorrect.

398. Even if a regulation allows the same idea carried by a given advertisement to be set forth in a "sanitized" form, such as banning the image of an attractive woman saying "Light My Lucky" while allowing a statement to the effect that cigarettes inerease sexual attractiveness, substantial costs still are imposed because the idea will be conveyed in a diluted form. 
the Court. ${ }^{399}$ Justice Rehnquist frequently raised this argument in the early commercial speech cases ${ }^{400}$ and Professors Jackson and Jeffries have developed the argument most fully. ${ }^{401}$

Jackson and Jeffries begin by assertimg that what commonly is referred to as commercial speech is not "speech" for first amendment purposes, it is actually part of the economic marketplace and may be regulated as economic activity. ${ }^{402}$ Having postulated the irrelevance of commercial speech for first amendment purposes, they analyze portions of the opmion in Virginia Board that set forth an economic rationale for the decision. That rationale can be summarized as the Court's behef that the Virginia statute impaired individual and aggregate economic efficiency. ${ }^{403}$ Referring to this aspect of the opimion, Jackson and Jeffries conclude that "econoimic due process is resurrected, clothed in the illfittmg garb of the first amendment."404

At the outset, we inust grant Jackson and Jeffries their characterization of this portion of the Court's holding in Virginia Board. As Professor Shiffrin has put it, "[i]t was strange for the Court to suggest that the first amendinent has been Chicago-school economics travelling incognito for all these years."405 Granting the accuracy of their characterization, however, does not mean that Virginia Board is a close cousin to Lochner. ${ }^{406}$ As noted above, the decision rests upon independent grounds, based in first amendment values. ${ }^{407}$

Jackson and Jeffries' argument works only if advertisements constituting verbal acts are conflated with the balance of commercial speech. If one grants Jackson and Jeffries their premise that commercial speech is merely another form of economic activity, then the economic due process argument follows. The Court then wonld be striking down econoinic regulations with which it disagreed, using the first amendinent as a pretext for impleinenting its econormic pohicies.

That premise, however, is valid only as to advertisements that actu-

399. For present purposes, I will define the evil of economic dne process as occurring where the Court strikes down legislation based upon a conflict between such legislation and the Court's own economic theory.

400. See, eg., Virginia State Bd. of Pharmacy v. Virginia Citizens Consumer Council, Inc., 425 U.S. 748, 784 (1976) (Rehnquist, J., dissenting) (citing Ferguson v. Skrupka 372 U.S. 726, 730 (1963) and Williamson v. Lee Optical Co., 348 U.S. 487, 490 (1955)).

401. Jackson \& Jeffries, supra note 46.

402. Id. at 2. Jackson and Jeffries also assert "commercial speech has no apparent connection with the idea of individual self-fulfillment ... the concept of a first amendment right of autonomy in matters of behef and expression stops short of a seller hawking his wares." Id. at 14. To the extent the argument set forth in Part III, supra, is correct, this argument is not.

403. For the Court's language, see supra note 46.

404. Jackson \& Jeffries, supra note 46 , at 30.

405. Shiffrin, supra note 147 , at 1227.

406. Lochner v. New York, 198 U.S. 45 (1905).

407. See supra note 46. 
ally constitute offers-using language that in and of itself creates a commercial obligation. ${ }^{408}$ With respect to any other form of commercial speech the economic due process argument fails. As to those forms of commercial speecli, the Court properly distinguishes economic activity from speecli related to that activity.

Significantly, Jackson and Jeffries rely upon Judge Bork's rigid interpretation of the scope of the first amendment for their assertion that commercial speech is without first amendment value. ${ }^{409}$ Thus, the arguments previously asserted against that position apply with equal force to the economic due process argument, and they ultimately undermine its force.

Admittedly, the dichotomy between underlying economic activity and speecli related to that activity might not always be easy to draw. This problem is especially likely to arise in situations involving, for example, the conduct of attorneys. In such situations the underlying economic activity is itself inevitably intertwined witl speech. The Court Inay well find itself struggling with cases sucl as Ohralik, where the line is blurred and the court quite correctly wishes to disapprove of the lawyer's economic activity.

In keeping witl my view that Ohralik is best viewed as a case involving a course of conduct that included speech, rather than a commercial speech case, the Court slould resolve this problem by first determining whetler the speecl involved was part of an independently regulable course of conduct. If it was not, the Court then should assume that the activity is protected by its speech eleinent. If the activity then departs froin speccli in sucli a way as to be independently regulablesuch as for duress or for fraud-the Court inay uplold regulations upon those aspects. While this may be an miperfect solution, it certainly is preferable to Jackson and Jeffries' assumption that commercial speech implicates no first amendment values. ${ }^{410}$

\section{The Leveling Argument}

A fourth argument frequently used to justify an intermediate level of protection for commercial speech is that granting full first amendment protection to commercial speech would dilute the force of that protection when applied to noncommercial speecl. The argument has its origins in Ohralik $^{411}$ and recently has been endorsed by Professor Scliauer. ${ }^{412}$ In Professor Schauer's words:

408. See supra note 166 .

409. Jackson \& Jeffries, supra note 46 , at 7-8.

410. Such an approach also is appropriate for addressing mixed speech problems in general.

411. See supra text accompanying note 67.

412. Schauer, Architecture, supra note 8. 
[W]ere existing first amendment rules to be applied to commercial speech, we can foresee similar dangers of doctrinal dilution, where 'doctrinal dilution' refers to the possibility that some existing first amendment rule would lose some of its strength because of the number of unacceptable applications it would generate when its new applications were added. ${ }^{413}$

Initially, a couple of characteristics about the leveling argument should be brought to the surface. First, the argument rigidly favors the status quo of first amendment protection. To put it another way, the leveling argument could have been used agamst the extension of first amendment protection to movies ${ }^{414}$ and falsehoods ${ }^{415}$ and is available for use in arguments about video games. ${ }^{416}$ This does not mean that the argument is bad, just that it is inherently conservative, and should be considered in hight of that fact.

Additionally, this argument is difficult to address because, at least as made by the Court, it is based upon the objectionable nature of unspecified speech that would be protected by the first amendment if full protection were given to commercial speech. ${ }^{417}$ Moreover, especially when made by the Court, the argument is essentially self-executimg. The Court refuses to extend full protection to commercial speech because it then would have to decrease the strength of full protection im order to uphold regulations it beheved were constitutional.

Even leaving these probleins aside, the leveling argument is fundamentally flawed. The argument first assumes that in the status quo all speech that receives full first amendment protection is of the same first amendment value, or at least is all above some threshold, though perhaps at differing levels of importance past that point. That assumption, however, is simply wrong. We will tolerate even false statements of fact, which the Court says have no constitutional value, to avoid chilling "speech that matters," the reference to which indicates that we are protecting perhaps a great deal of speech that does not matter.

Still, one could argue that absent the utilitarian rationale for protecting such speech inherent in the concept of "chill," we may deny protection to some speech to preserve the speech that matters. One could argue further that no such utilitarian rationale exists for protecting com-

413. Id. at 1194.

414. Mutual Film Corp. v. Industrial Comm'n, 236 U.S. 230 (1915). The argument was not in fact used in the case.

415. New York Times Co. v. Sullivan, 376 U.S. 254 (1964).

416. See Caswell v. Licensing Comm'n, 387 Mass. 864, 444 N.E.2d 922 (1983).

417. Professor Schauer avoids this problem in part by referring to the potential problems that would arise from applying the first amendment to areas currently regulated by securities laws. Schauer, Architecture, supra note 8, at 1196. For an argument that such application would be appropriate, see Schoeman, The First Amendment and Restrictions on Advertising of Securities Under the Securities Act of 1933, 41 Bus. LAW. 377 (1986). 
mercial speech. Such an argument, however, would be entirely beside the point. The argument still must hinge on the notion that the speech causing the leveling (here commercial speech) is somehow demonstrably less "valuable" than the speech we seek to protect. The argument thus is irrelevant until one proves that the speech at issue is less valuable. And that is where the current use of the argument falls apart.

Simply put, the Court has never engaged in the type of analysis necessary to demonstrate that, as a matter of first amendment theory and in light of first amendment values, commercial speeeh is less valuable than other types of speech. Rather, it now uses the leveling argument to fill that role, resulting in an obvious tautology. ${ }^{418}$ For the argument to be at all relevant, the Court inust first justify its behef in the inferior value of commercial speech by reference to the values of the first amendment.

On a pragmatic level, it seems clear that the Court erred in Ohralik by engaging in a first amendment analysis at all. The speech there certainly was regulable as occurring merely as part of a larger, independently regulable, course of conduct. Leveling would have occurred had Ohralik's speech becn protected because the non-speech elements would have received protection to which they were not entitled.

Regulations upon commercial speech should not be upheld for fear that striking thein down would dilute the overall protection offered by the amendment. In each case the Court should analyze the relevant speech carefully to determine whether the speech fosters first amendment values such as rationality and self-realization. ${ }^{419}$

Where commercial speech does enhance either value, in the sense they are used in Part III, the leveling argument loses its force because the speech is then indistingmishable, on a value level, from other forms of speech, or speech on other topics, the Court presumably seeks to protect froin the diluting effects of commercial speech.

This seems paradoxical until we consider that the otler speech the Court is talking about is almost certainly inerely speech on other topics; the Court's reference is not value-based at all. ${ }^{420}$ While the Court might find certain reasons to uphold a regulation that apply umiquely to speech about commercial topics, it is hard to see wliat such reasons might be. If such reasons do exist, there is no need to worry about leveling because principled distinctions may be drawn that will preserve the level of protection.

418. Professor Schauer avoids the tautology by explicitly assuming that commercial speech is substantively less valuable than other types of speech. Schauer, Architecture, supra note 8, at 1185 86.

419. Where the speech is not related to this goal, it does not present leveling problems because it does not qualify for full protection in the first instance.

420. See supra text accompanying notes 374-79. 
If no such unique reasons exist, the Court nuust either strike down the regulation or nake an exception to the protection of the first amendnient unjustified by reference to the values of the first amendnient. As long as the latter result is reached exphicitly, either alternative is preferable to the current state of affairs, where the dangers that will trigger the leveling are left unspecified and unanalyzed. Of course, it would be preferable fully to protect commercial speech that fosters first amendment values.

In sum, the leveling rationale better serves as a reason carefully to analyze speech than as a reason to provide a lesser degree of coverage to that speech. Where commercial speech directly fosters the rationality or self-realization values, the speech does not establish a lower level to which the rest of the amendment's protection will be diluted-the speech is of equivalent value and should be treated that way.

$\mathrm{V}$

IMPLiCATIONS OF INCREASED Protection for COMMERCIAL SPEECH UPON REgULATIONS OF FALSE AdVERTISING

As the leveling argument poimts out, mcreasing the level of first amendment protection afforded commercial speech raises numerous concerns for the Court. Perhaps the niost persistent concern is that mcreasing such protection would impair the legitimate efforts of the states to protect consumers against false advertismg. This Part considers the broad range of commercial speech that cannot be deemed false and the limited way in which the balance of commercial speech inay be considered false and concludes that the Court's concern is largely unfounded.

Both federal and state governments have erected a substantial body of law designed to ferret out and pumish false or misleading advertiseinents. ${ }^{421}$ The prohibition of false advertising is a substantial governmental end, and if increasing protection for commercial speech threatened the attainment of that end we would be less willing to increase the level of protection.

Extendimg full first amendment protection to commercial speech, however, is not inconsistent with regulating false or inisleading advertiseinents, so long as the increase in protection is tied to the value structure of the first amendment. First, we should renieniber Professor Lowenstein's insight that much advertismg simply is not truth-evaluative at all. ${ }^{422}$ Such advertismg conveys ideas that, as noted above, are not

421. For an example of such regulations operating in the commercial speech context, see National Commission on Egg Nutrition v. F.T.C., 570 F.2d 157 (7th Cir. 1978).

422. See supra note 342 . 
susceptible of governmental determinations of falsity.

Under the early doctrinal language of the first amendment, such speech constitutes a statement of opinion as to the frequently intangible or amorphous effect of purchasing a product or service. The fact/opinion dichotomy arose from Justice Powell's famous dicta in Gertz that:

Under the First Amendment there is no such thing as a false idea. However pernicious an opinion may seem, we depend for its correction not on the conscience of judges and juries but on the competition of other ideas. But there is no constitutional value in false statements of fact. Neither the intentional he nor the careless error materially advances society's interest . . . 423

If we are to take this doctrine seriously, then advertisements that do no more than set forth opinion (or ideas that should be characterized as opinion) should not be subject to regulation as false advertisements. Although this answer is not a panacea, ${ }^{424}$ simply going through the process of determining whether an advertisement constitutes a statement of fact or of opinion will inuprove the analysis of commercial speech cases immeasurably. ${ }^{425}$ Additionally, the fact/opinion distinction retains enough flexibility to address a wide range of advertisements, largely because of its emphasis upon the context of the speech. ${ }^{426}$

Forcing the government to prove, or at least be capable of proving, a given instance of speech to be false before the government can regulate it fits well with the Court's recent treatinent of Gertz. In Milkovich v. Loraine Journal Co ${ }^{427}$ the Court held that Gertz did not "create a wholesale defamation exception for anything that might be labeled opinion." 428 The Court was concerned that statements that appear to be opinion but that "imply an assertion of objective fact" 429 not be immunized from defamation actions.

The Court resolved the need to protect commentary and the like by constitutionalizing the falsity element of a defamation action. Relying

423. Gertz v. Robert Welch, Inc., 418 U.S. 323, 339-40 (1974) (footnote omitted).

424. For an excellent discussion of the shortcomings of the fact/opimion distinction, see Schauer, Language, Truth and the First Amendment: An Essay in Memory of Harry Canter, 64 VA. L. REV. 263 (1978).

425. The test to determine whether a given statement is one of fact or of opinion varies among the circuits and the states. The most widely used formula is taken from Ollman v. Evans, 750 F.2d 970, 976 (D.C. Cir.) (en banc), cert denied, 471 U.S. 1127 (1984). The Ollman test examines the specificity and verifiability of the statement, together with the social and linguistic context in which the statement is made.

426. Thus, in contexts where consumers more likely expect commercial speech to be factual (perhaps im the advertisement of warranties, etc.) a more stringent standard would be applied, so that only speech that could not be considered factual would be immune from regulation.

427. 110 S. Ct. 2695 (1990).

428. Id. at 2705 .

429. Id. 
upon Philadelphia Newspapers, Inc. v. Hepps ${ }^{430}$ the Court held that "a statement on matters of public concern must be provable as false before there can be liability under state defamation law."431 Justice Brennan's dissent aptly noted that the Court's standard would not substantially alter the course of defamation actions because the verifiability of a statement, with the inevitable attendant contextual concerns, has long been used by courts seeking to isolate "opinion." 432

Advertisements linking cigarettes or cars or soap or whatever with sexual attractiveness, or any other cliaracteristic, therefore should be free froin regulation as false advertisements because there is no regulatory body, including courts and juries, capable of determining whether they are true. Extending increased protection to this type of commercial speech poses no threat wliatsoever to proper regulation of false and unisleading advertising.

Of course, informational commercial speech falls outside this category. It also does not, however, pose inuch of a problem for regulations of false advertising. Purely informational commercial speecl is, generally speaking, more verifiable than persuasive commercial speech. Thus, while the latter will tend to fall on the opinion side of the fact/opinion dichotomy, the former will not. Consequently, informational commercial speech is not immunized froin regulation by Gertz.

The ways in which such speech may be said to be false depends upon what tlie speech is trying to do. An invitation to deal, for example, is false only if the speaker does not hold the intent to deal witli persons responding to an advertiseinent. Where such speech is false, as where a merchant advertises that she will sell a good at a certain price when she knows that she will not, it is regulable for such falsity. In that event the false statement may be said to be an inplied representation that the speaker intended to sell the good at the advertised price. ${ }^{433}$ The ouly real problein in regulating sucli falsity arises from tlie problem of chilling speech. The argument would be that informational commercial speakers might refram froin speaking because a jury miglit misinterpret their

430. 475 U.S. 767 (1986).

431. Milkovich, 110 S. Ct. at 2706. The Court in Milkovich, as in Gertz, left the states free to decide what level of proof a private figure would have to meet to maintain an action for defamatory statements on matters of public concern. Id. at 2707-08. That question is not relevant to the level of first amendment protection afforded commercial speech.

432. Id. at 2708 (Brennan, J., dissenting). Although Justice Brennan and Justice Marshall dissented on the facts in Milkovich; the Court was unanimous on the legal standard. Id. (Brennan, J., dissenting). As noted supra note 425 , the verifiability enquiry was at the heart of Judge Starr's opinion in Ollman v. Evans, 750 F.2d 970, 976 (D.C. Cir.) (en banc), cert. denied, 471 U.S. 1127 (1984).

433. A sanction under such a thcory would require a showing of the requisite intent-a promise made without the intent to perform. See, e.g., Cal. Civ. Code $\S 1572(4)$ (West 1982 \& Supp. 1990). 
intent and erroneously sanction them for publishing a false advertisement.

That argument, however, is weak. Simply put, even speakers who engage in core speech run the risk that a jury may misinterpret their state of mind and find, for example, actual malice sufficient to warrant damages for libel. New York Times and Gertz held that some false speech must be tolerated to avoid chilling speech that matters and implemented that holding by shifting the focus of libel inquiries from the content of the speech alone to the content of the speech plus the speaker's state of mind. The addition of this mens rea requirement gave speakers a kind of bufier zone that allows them to speak more freely because they are less fearful of erroneous sanctions.

The false speech envisioned by New York Times involves a false statement of fact. Informational cominercial speech functions, however, in a fundamentally different way. The only way an advertisement to sell $X$ drug at $Y$ price can be false is if the speaker does not intend to sell on such terms when she publishes the advertisement. The false statement of fact is the statement, implied by law, that the speaker intends to follow through on the speech at the time the speech is made.

Thus, the New York Times buffer zone is (generally speaking) already built into regulations of informational commercial speech because the false statement itself relates to the speaker's state of mind in publishing the advertisement. The false intent element of an action for promissory fraud secures the buffer zone. The only type of regulation that would not have such a built-in buffer zone would be one that imposed strict liability upon advertisers. And it would be hard to justify refusing to extend full first amendment protection to commercial speech on the ground that such extension would prohibit states from forcing advertisers to sell at a price misprinted in a newspaper. ${ }^{434}$

Thus, the concern expressed in Virginia Board's footnote 24 appears largely the result of a failure to examine critically the range of commercial speech and the ways im which such speech could be eonsidered false. The Court need not have worried that it was undermining valid efforts to regulate false advertising. ${ }^{435}$ Its concern that granting full first amendinent protection to cominercial speech will undermine regulations of false advertising reflects the same failure critically to analyze commercial

434. Of course, the interesting question then becomes whether such a strict liability statute would be unconstitutional as well as unwise. Given the foregoing analysis, I would be inclined to believe that it would. My guess, however, is that there would be very few sucl statutes to strike down, and striking them down would not significantly impair the regulation of true consumer fraud, as opposed to accident.

435. This also means that as to informational commercial speech the overbreadtl doctrine is not needed because any valid regulation applying to informational commercial speech already will contain the buffer zone that the doctrine seeks to establish. 
speech that led the Valentine Court to deny protection to commercial speech altogether.

\section{CONCLUSION}

The commercial speech doctrine is in disarray. The Court has settled upon no consistent rationale for protecting commercial speech, and it uses a range of dubious rationales to deny protection to commercial speech. The Court secms unwilling to analyze commercial speech as it would other speech; it fails accurately to appraise the inessage conveyed by commercial speech and the significance of those inessages in the context of first amendment values. This disarray has direct and adverse consequences upon first amendment values because commercial speech directly furthers those values in a variety of ways. Therefore, at a minimum, commercial speech deserves a substantially greater level of attention than it receives today.

With such attention, the value of commercial speech can be demonstrated rather than ignored in favor of finding expedient ways to uphold economic regulations that are in fact speech regulations. Under such a regime, commercial speech generally will receive full first amendment protection. As Justice Brennan aptly put it, there is simply "no reason why commercial speech should be afforded less protection than other types of speech where ... the government seeks to suppress accurate information concerning lawful activity." 436

436. Posadas de Puerto Rico Assocs. v. Tourism Co., 478 U.S. 328, 350 (1986) (Brennan, J., dissenting). 